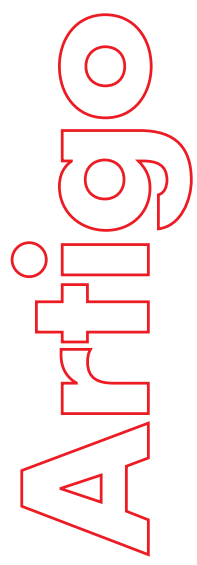

\title{
MEMORIAL PROFESSOR TITULAR GEOGRAFIA- CARTOGRAFIA NO TEMPO \& NO ESPAÇO
}

PROF. DR. RAFAEL SANZIO ARAÚJO DOS ANJOS

p. $01-76$

revista

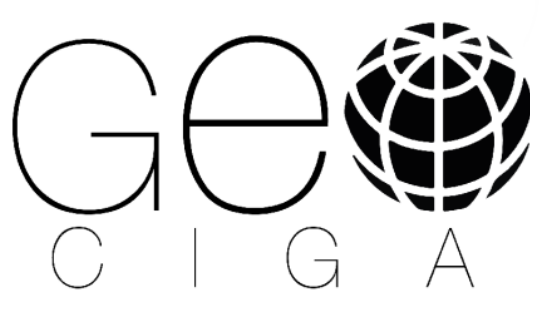

Revista Eletrônica:

Tempo - Écnica - Erritório,

V.7, N.1 (2016), 1:76

IŚSN: 2177-4366

DOI: https://

doi.org/10.26512/

ciga.v7i1.16677
Como citar este ar tigo:

ANJOS, Rafael Sanzio Araújo. MEMORIAL PROFESOR TITULAR

GEOGRAFIA-CARTOGRAFIA NO TEMPO E NO ESPAÇO

Revista Eletrônica: Tempo - Técnica - Território, v.7, n.1 (2016), p. 1:76

ISSN: 2177-4366. DOI: https://doi.org/10.26512/ciga.v7i1.16677

Disponível em: http://periodicos.unb.br/index.php/ciga

Este obra está licenciado com uma Licença Creative Commons Atribuição-NãoComer cial 4.0 Internacional. 


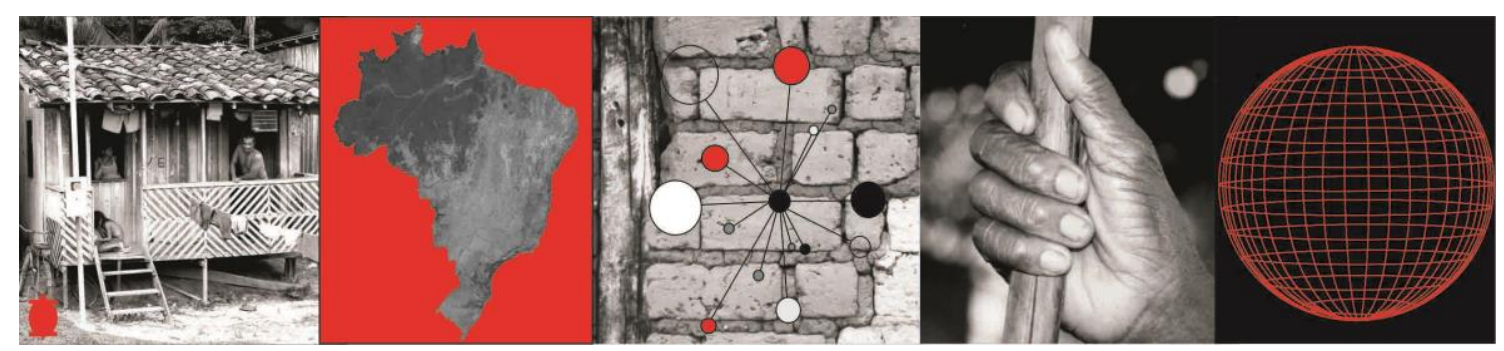

\title{
MEMORIAL PROFESSOR TITULAR GEOGRAFIA NO TEMPO E NO ESPAÇO
}

PROF. DR. RAFAEL SANZIO ARAÚJO DOS ANJOS

\author{
UNB - IH - GEA - CIGA \\ BRASÍLIA - DISTRITO FEDERAL
}

OUTUBRO - 2016 


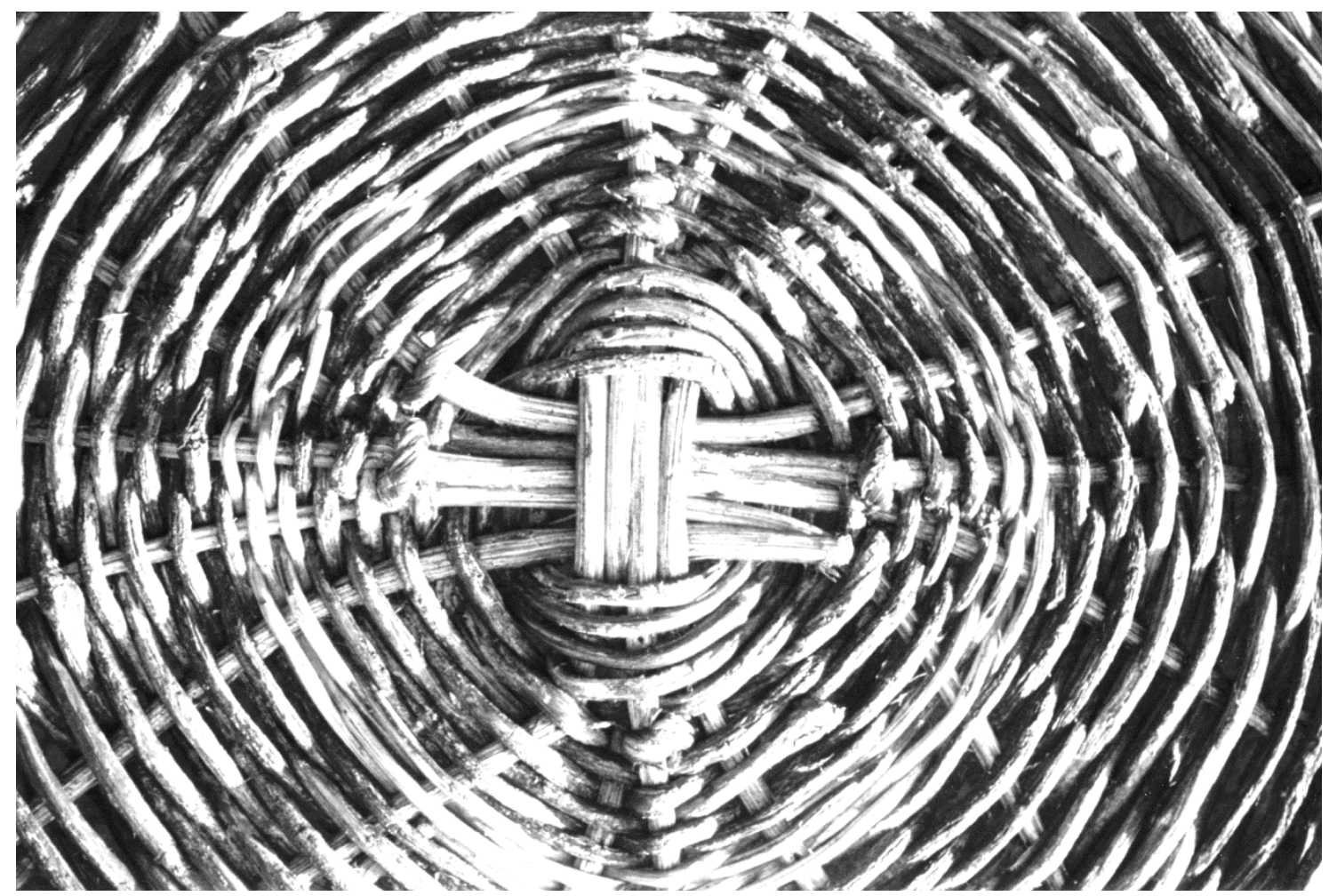

FOTO: Detalhe de cesto de cipó. recôncavo da Bahia, 2002 Rafael Sanzio

"A nossa riqueza coletiva é constituída por nossa diversidade, o "outro", indivíduo ou sociedade, é precioso para nós na medida em que é diferente de nós." 


\section{SUMÁRIO}

Nota introdutória .05

1. Alguns antecedentes estruturais da vida e as referências espaciais: a região do recôncavo e a cidade de Salvador. .08

2. Os anos 1980: a formação básica na UFBA, os trabalhos, os projetos e a opção pela acadêmia....................................................................................17

3. Os anos 1990-2000: o mestrado na fau, o doutoramento na Poliuspird, a expansão do projeto GEOAFRO, as publicações e o pósdoutoramento (MRAC-BE)

4. Os anos 2010. As publicações de consolidação do projeto GEOAFRO, o fortalecimento do grupo de pesquisa, do PPGEA e do CIGA-UnB 33

5. As pesquisas básicas, os projetos estruturais, os conceitos e os resultados: um breve balanço. .37

6. O agora 2015: as pesquisas e os projetos em operacionalização..................................................................................................69 


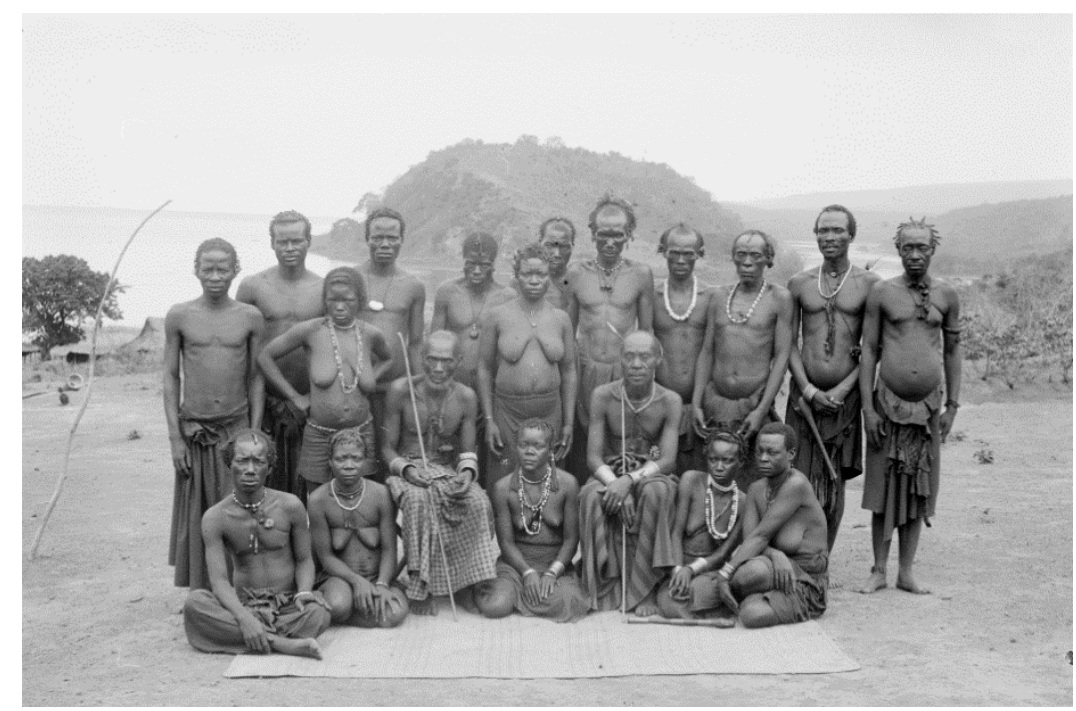

Foto anônima comunidade uruá com o chefe Calamata sentado. Baixo congo. Acervo tervuren-be.

\section{NOTA INTRODUTÓRIA}

\section{Yàgò!}

Com a saudação de licença em Yorubá, estou pedindo autorização aos meus ancestrais e antepassados para contar a minha história geográfica-cartográfica a esta banca ilustre que a existência esta me possibilitando dialogar. Duas dificuldades me foram configuradas quando tive que "parar" para construir este Memorial: primeiro, mais um desafio de exercitar a capacidade de síntese para um baiano da Região do Recôncavo que gosta de falar e se estender e, o segundo, na escolha do caminho para esta construção. O que estava colocado era na verdade rever as minhas histórias profissionais que se confundem com as da minha vida no sentido largo (passado, presente e futuro). A Historiografia enquanto possibilidade de estruturação de um trabalho no tempo e no espaço pode ser eficaz se houver atenção para minorar a rigidez cronológica e os cuidados necessários com a concepção linear e restritiva dos eventos e passagens. Tomei esta direção e ao longo do percurso foi possível fazer correlações e ter algumas respostas que sem esta abordagem talvez não chegasse ou chegaria com maior dificuldade. Penso que pelo meu lado capricorniano e "terra", sempre vislumbrei uma Geografia que teria que estar comprometida em tornar o mundo e suas dinâmicas compreensíveis para a sociedade, de dar explicações para as transformações territoriais e de apontar soluções para as incompatibilidades e incongruências dos distintos espaços com suas heterogeneidades. São com estas premissas que os instrumentos geográficos 
vão ocupar um lugar significativo nas minhas práticas, sobretudo a cartografia e a fotografia. O primeiro pela ampla capacidade de representação gráficas do mundo real e por se firmarem de forma crescente como a mais relevante ferramenta das interpretações e leituras do território. Os mapas possibilitam revelar graficamente o que acontece na dinâmica do espaço e tornam-se cada vez mais imprescindíveis por constituírem uma ponte entre os níveis de observação da realidade e a simplificação, a redução, a explicação e de pistas para a tomada de decisões. Apesar das potencialidades não perco de vista que um mapa não é o território, mas que nos produtos da cartografia estão as melhores possibilidades de sua representação. A fotografia como registro documental é outro recurso importante no processo do conhecimento geográfico, sobretudo pelas representações e interpretações do tempo, do espaço, da sociedade, que não se cristalizam e não são estáticas. No registro fotográfico de um ambiente ou de uma matriz cultural, podemos constatar as referências de uma estrutura social, que nos possibilita observar se esta é rica ou pobre, justa ou discriminatória, dentre outras possibilidades de interpretações espaciais. Sejam nos detalhes das matrizes culturais ou nas paisagens geográficas, as fotografias não se restringem a um mero congelamento do momento, mas a uma forma de olhar e sermos olhados. Por isso, entendemos a foto como um instrumento estratégico no processo de conhecimento do que aconteceu e acontece verdadeiramente em um território.

Com estas premissas, elaborei este Memorial estruturado em seis partes que dialogam, de certa forma, entre elas. A primeira faz um retrospecto de algumas referências das minhas infância-adolescência-juventude sobretudo que vão marcar decisivamente o caminho profissional que vou seguir, acreditar e praticar. A segunda parte trata da formação em Geografia no Instituto de Geociências da Universidade Federal da Bahia, os projetos, estágios e trabalhos que delinearam um caminho que não teria mais retorno. No terceiro momento do Memorial são focados os contextos de realização do Mestrado em Planejamento Urbano na FAU-UnB; do vínculo e aberturas junto ao Departamento de Geografia da UnB e a continuidade das pesquisas na sequência no Programa de PósGraduação em Informações Espaciais (POLIUSP).Ainda nesta parte citamos a expansão do Projeto Geografia Afrobrasileira(Projeto GEOAFRO) no país e fora dele, assim como os seus desdobramentos com publicações, exposições temáticas e programas educativos (oficinas temáticas). É neste processo que o Projeto de Pós-Doutoramento toma conformação e não sabia eu há que outros caminhos mais longos a pesquisa proposta me levaria.A quinta parte mostro os desdobramentos das pesquisas e projetos 
realizadas fazendo uma abordagem dos seus resultados e produtos com exposições, livros, vídeos, oficinas, artigos, dentre outros procedimentos que agregam o tripé da pesquisa, do ensino e da extensão buscando "conversar" com a sociedade civil e o setor decisório usando linguagens de maior eficácia. Na última Parte o foco está no momento atual e a operacionalização dos estudos e projetos. Com esta estruturação sintética busco reconstituir os elementos fundamentais do meu processo de vida profissional, assumindo já, o risco de ter deixado de tratar de um ou outro aspecto também relevante dessa trajetória. Tem um mestre chileno chamado Doro Ortiz, que morou muitos anos em Brasília e certa vez ao estar com ele o mesmo me disse: "o erro não é um erro! Mas uma oportunidade para descoberta e chegar ao acerto." Fiquei um tempo pensando, sem entender direito a sua mensagem e num momento de clareza que veio, eu percebi que o olhar direto, de frente, sem medo para o erro, é onde esta o acerto. O erro perde a sua força! Bem, errei muitas vezes na minha trajetória e eles me ajudaram a acertar também, muitas vezes!

Brasília, outubro - 2016 


\section{ALGUNS ANTECEDENTES ESTRUTURAIS DA VIDA E AS REFERÊNCIAS ESPACIAIS: A REGIÃO DO RECÔNCAVO E A CIDADE DE SALVADOR}

No sentido de dar maior sistematização nas referências e eventos marcantes da minha trajetória geográfica e suas significações, estruturei o texto em itens marcantes no tempo-espaço, sempre que possível, associados a diagramas, imagens fotográficas e cartográficas. Nesta Parte I destacamos o seguinte:

1. Apesar de ter nascido (1958) em Santo Antônio de Jesus, Região do Recôncavo da Bahia o meu pai José Tibúrcio dos Anjos, me levava sempre que possível a Salvador para acompanhamento de um problema de vista que eu tinha. Com isso foi possível conviver mais com meu avô paterno (Jacinto Manoel dos Anjos) que era Mestre de Ofício da Escola Técnica da Bahia e fazia parte da Diretoria do Sociedade Protetora dos Desvalidos (sede no Terreiro de Jesus, Centro de Salvador). Ele me levava para a Sociedade com ele (era o único neto disponível) e eu observava as suas reuniões; as solicitações das pessoas de matriz africana excluídas e suas necessidades; os móveis de jacarandá e vinhático; as situações emergenciais que eles tinham que resolver e estas passagens ficaram gravadas. Estas vivências semearam em mim algo maior que identifico no trabalho que busquei realizar na minha prática profissional, nas minhas referências ideológicas e nos caminhos da vida. A Foto 01 mostra os membros da Diretoria da qual meu avô participava e eu olhava para ela neste período na parede do corredor da sua casa no bairro de Santo Antônio Além do Carmo no Centro de Salvador. Aqui está um dos braços das raízes que seguram a minha árvore!

2. O Mapa 01 mostra as principais cidades que circulei na minha infância e Feira de Santana, era onde morava a minha avó materna (Maria dos Anjos, mãe de minha mãe Antonieta Araújo dos Anjos) e minhas tias. Era ela que nos levava (eu e mais quatro irmãos) nas férias escolares para ficar uns dias na sua casa. Três experiências ficaram marcadas em mim: A. Ver e ajudar ela a fazer os bombons e pirulitos no fogão de lenha para serem vendidos pelos baleiros no dia seguinte (ficou viúva cedo e esta era a sua fonte de renda principal) me deu uma dimensão da sobrevivência; do conhecimento ancestral firmado e do comércio informal (herança colonial); B. A noite, no escuro do quarto, ela contava para mim e meus irmãos as história do Reino de Aruanda, as quais me levavam a um 
mundo imaginário que me dava pertencimento na história contada e C. Ela cozinhava em tachos de cobre e almoçávamos juntos aos tachos comendo de mão. A matriz Yorubá é marcante nessas referências e a Foto 02 do Sr. Chico com sua esposa Vicência (tia da minha mãe) confirma estas referências (pano da Costa no ombro da Senhora). Estas vivências de infância me fazem ter uma ligação com Feira de Santana até hoje! Sempre que viajo de carro de Brasília para Salvador, paro lá, vejo minhas tias, vou na feira, faço compras, revejo espaços e uma parte minha se "alimenta" de algo que não sei claramente, mas que continua sendo importante;

3. Outro contexto marcante vem da linhagem de professoras (todas as tias maternas eram professoras) e da parte de pai o meu avô Jacinto, com os filhos formados e referências de bons estudantes (ver na Foto $\mathbf{0 3}$ em anexo onde o meu pai Tibúrcio é o segundo da "escada"). As cobranças nos estudos por parte dos meus pais se constituiam em uma certa ordem familiar, onde ouví muitas vezes: "Estudo é tudo!". De certa maneira o "exigente" que convive comigo e atuo com meus filhos, com as mulheres, com a equipe de trabalho tem haver com estas referências. Entendo claramente que era uma herança do sistema escravista que ia sendo passado do Brasil Colonial ao Brasil República que sem estudo e sem ofício (uma profissão) não se era ninguém!

Outro ponto desta parte se refere a uma escolha que minha mãe fez dentre os cinco filhos (eu sou o terceiro, portanto o do "meio") para acompanhá-la nas buscas com suas amigas por peças antigas coloniais na Região do Recôncavo. Estas (panelas de ferro, bancos de jacarandá, consoles, cristaleiras, tacho de cobre, arca, dentre outras) posteriormente eram restauradas para uso na decoração das casas. Fui o filho escolhido para ir com ela nas pequenas viagens e nessas andanças eu estive em ambientes diversos e conhecimento de mobiliário até então desconhecidos. Fui em várias fazendas do sistema escravista e com a estrutura espacial colonail ainda mantida (casa grande, senzalas, área de plantio, etc.), além de ouvir as histórias das peças (o tipo da madeira, o artesão que fez, o estilo, etc). Estas experiências, deu uma dimensão da arquitetura, da tecnologia e do mobiliário colonial que era conduzido - operacionalizado pelos povos africanos e seus descendentes. Ao longo dos estudos do Projeto GEOAFRO vou perceber claramente o quanto estas referências e "conhecimentos guardados" me eram preciosos para integrar numa Geografia de mariz africana que não estava nos compêndios e nem no sistema de ensino oficial e muito menos no processo de 
planejamento e intervenção no território, assim como na academia.Estas matrizes vividas e vivênciadas somente vão ser acordadas ao longo do curso de Geografia na UFBa. (final dos anos 70 e início dos anos 80) e nos estudos do Projeto GEOAFRO (meados da década dos anos 80).A seguir outros pontos que merecem registro.

\section{REFERÊNCIAS DOS MOVIMENTOS DE RAFAEL SANZIO ARAÚJO DOS ANJOS - DÉCADA 1960 -}

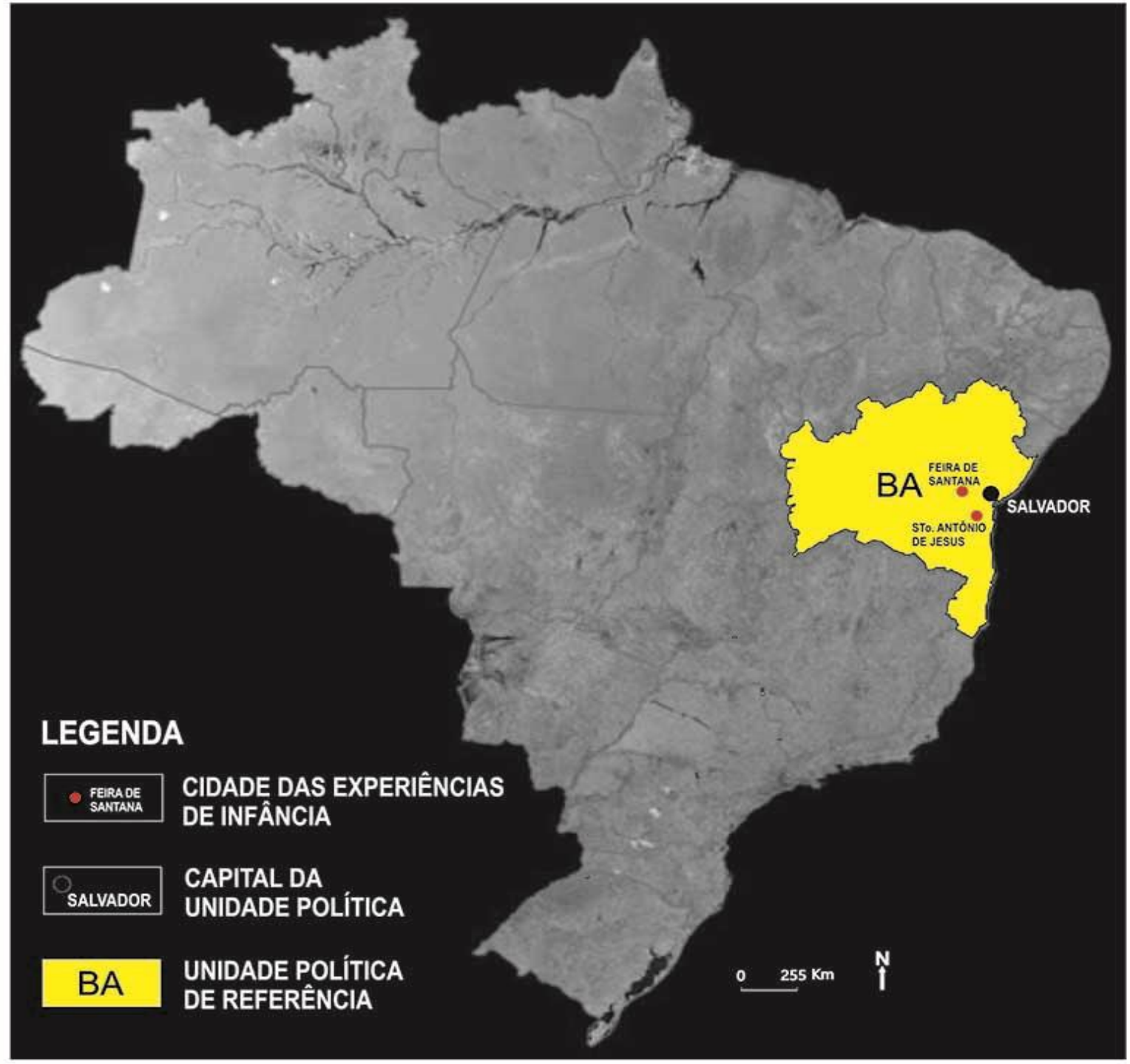

B Base Cartográfica IBGE . 2010/Imagem de Satélite: Mosaico semi-controlado de Imagens Landsat - Nasa - USA 2013 ( Projeto Geográfico e Cartográfico by Geog. Rafael Sanzio A. dos Anjos - Centro de Cartografia Aplicada e Informação Geográfica - Universidade de Brasília - Brasilia - DF. 2015. E-mail:quilombo@unb.br/Tele: 55 (61) 3107-5242

Mapa 01 


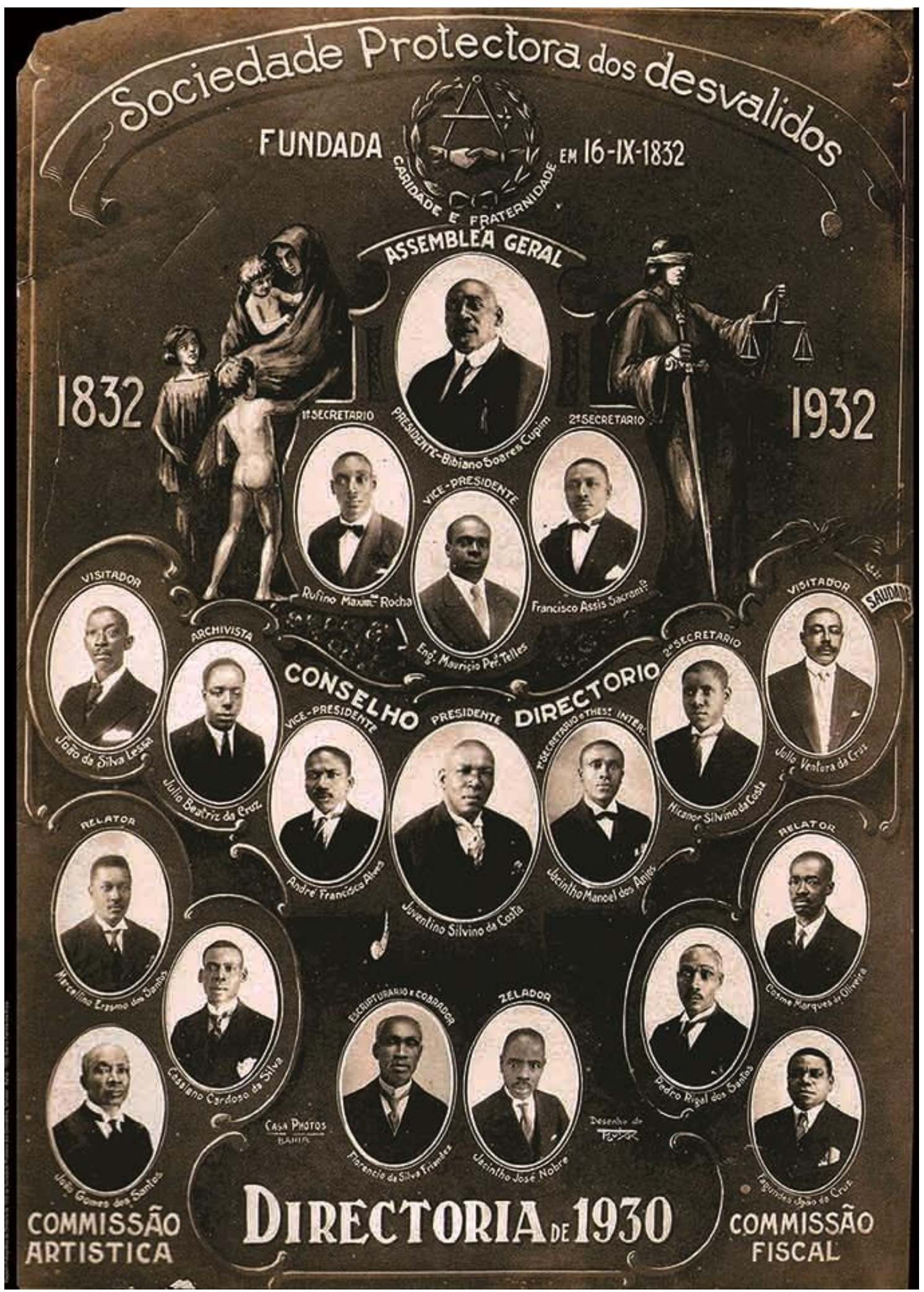

Foto 01: Fonte: Acervo Família Dos Anjos. Registro da Diretoria da Sociedade Protetora dos

Desvalidos 1930. Salvador - Bahia 


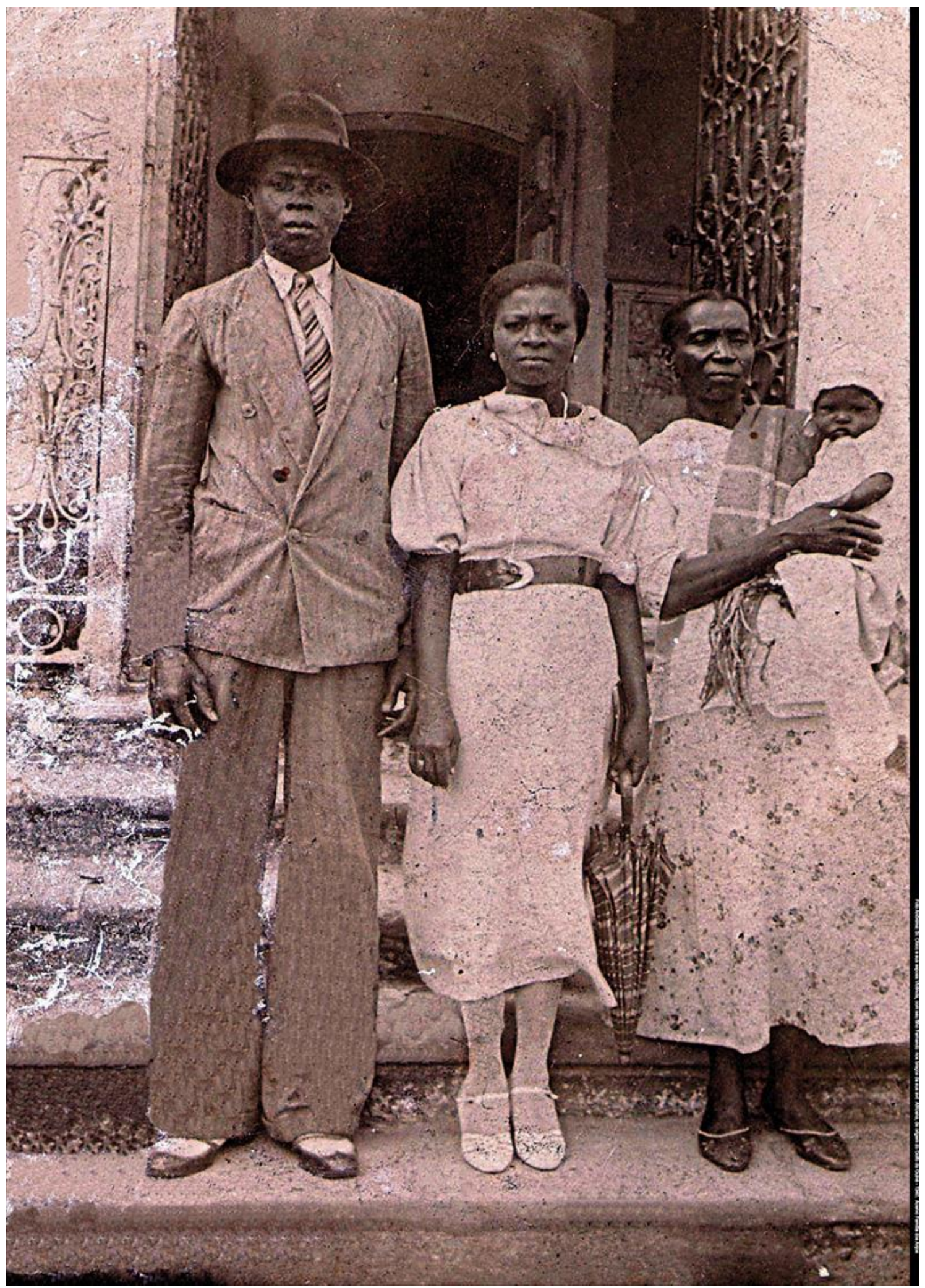

Foto 02: Fonte: Acervo Família Dos ANJOS. Sr Chico, sua Esposa Viscência, sua mãe e o filho Fernando. Salvador, Bahia, Anos 30 do Século XX 


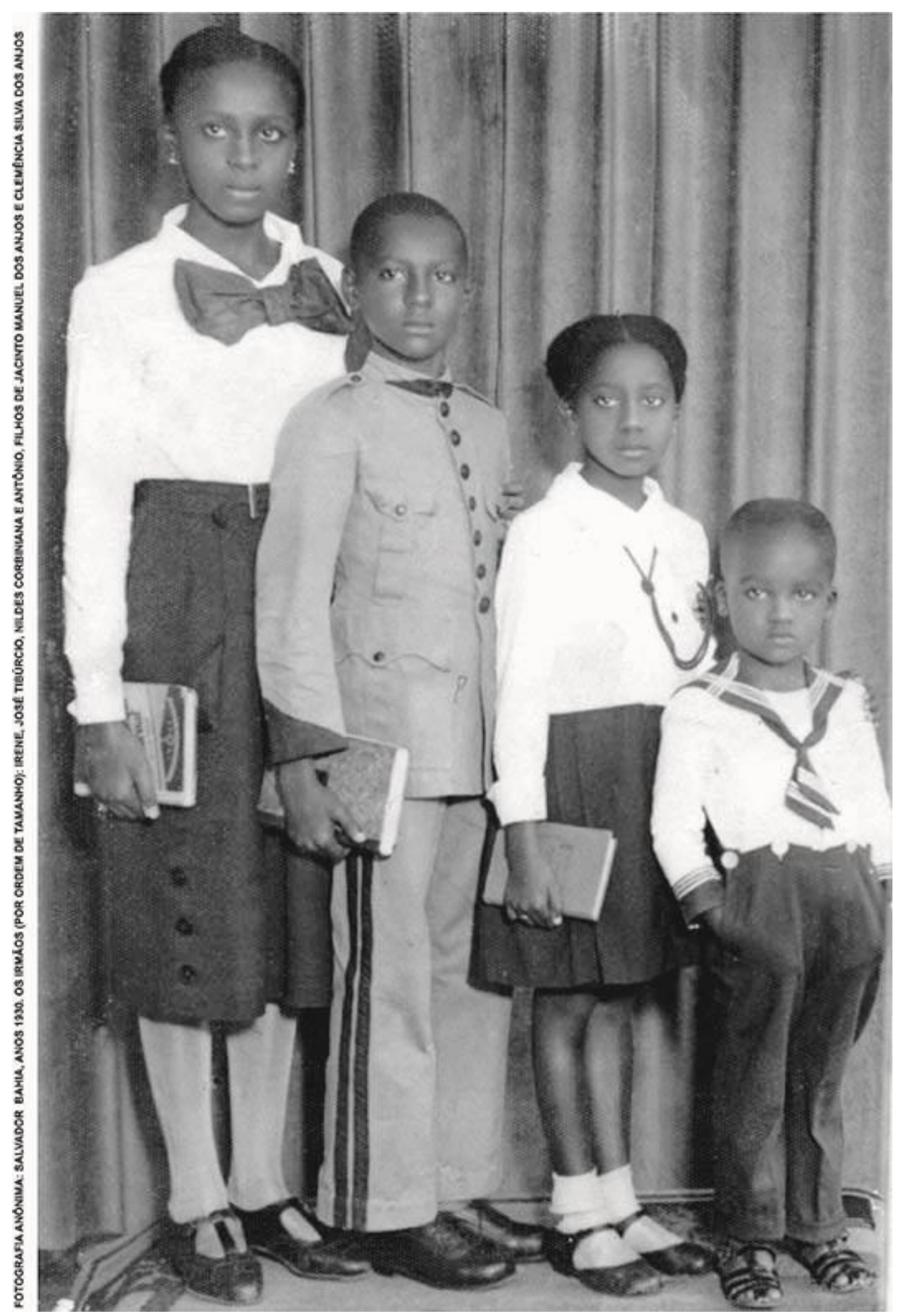

Foto 03 


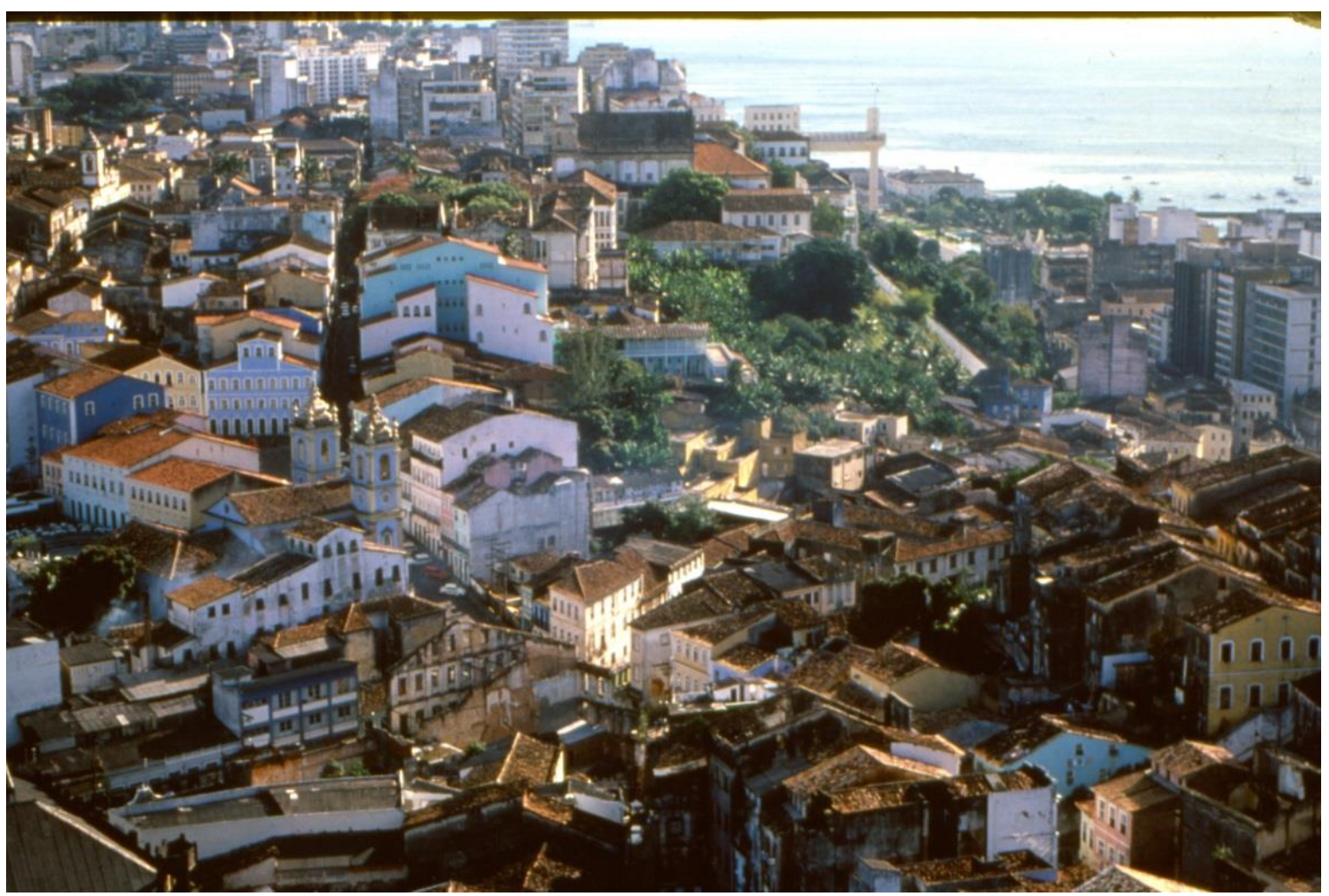

Foto 4: Vista aérea panorâmica do centro de Salvador. Acervo Bahiatursa. 1985

4. O meu $2^{\circ}$. Grau foi um curso técncio em "Desenho" realizado na cidade de Salvador no Colégio Central (colégio público de referência na Capital). As disciplinas de Desenho Topográfico e Arquitetônico vão me chamar mais atenção e eu sabia que aí eu resolveria um destino! A escolha pela Geografia surge nesse movimento da Cartografia que passei a aprender a partir do Curso Técnco. O meu Tio Antônio (Eng. Civil, irmão de meu pai, foi fundamental nesse processo nas conversas objetivas do que eu podia realizar com esses conhecimentos);

5. Na UFBa. (ingressei em 1978) e já fui convidado pelos colegas mais antigos a ir para o $3^{\circ}$. Encontro Nacional de Geógrafos realizado em Fortaleza de 19 a 27 de julho de 1978. Sabia que algo importante estava se discutindo naquele evento mas não tinha dimensão do que se tratava. No ano seguinte fui para o $1^{\circ}$. Encontro Nacional de Estudantes de Geografia em Goiânia (18 a 22 de dezembro de 1979). Estes dois eventos foram estruturais para o entendimento da importância da AGB e de uma "Geografia" que não era a ensinada somente na universidade. Nessa inquietação surge o TG (Grupo de Trabalho em Geografia) 
formado por alguns colegas com os mesmos questionamentos, sobretudo referente a "Geografia Invisível da cidade de Salvador" que nos aparecia de forma bem visível, mas não aceita. A Foto 05 mostra uma imagem aérea de Alagados na Cidade Baixa em Salvador com sua tiplogia de materiais aproveitados e um sistema de circulação precário e vulnerável. Esta Geografia Urbana de exclusão era uma das inquietações do TG.

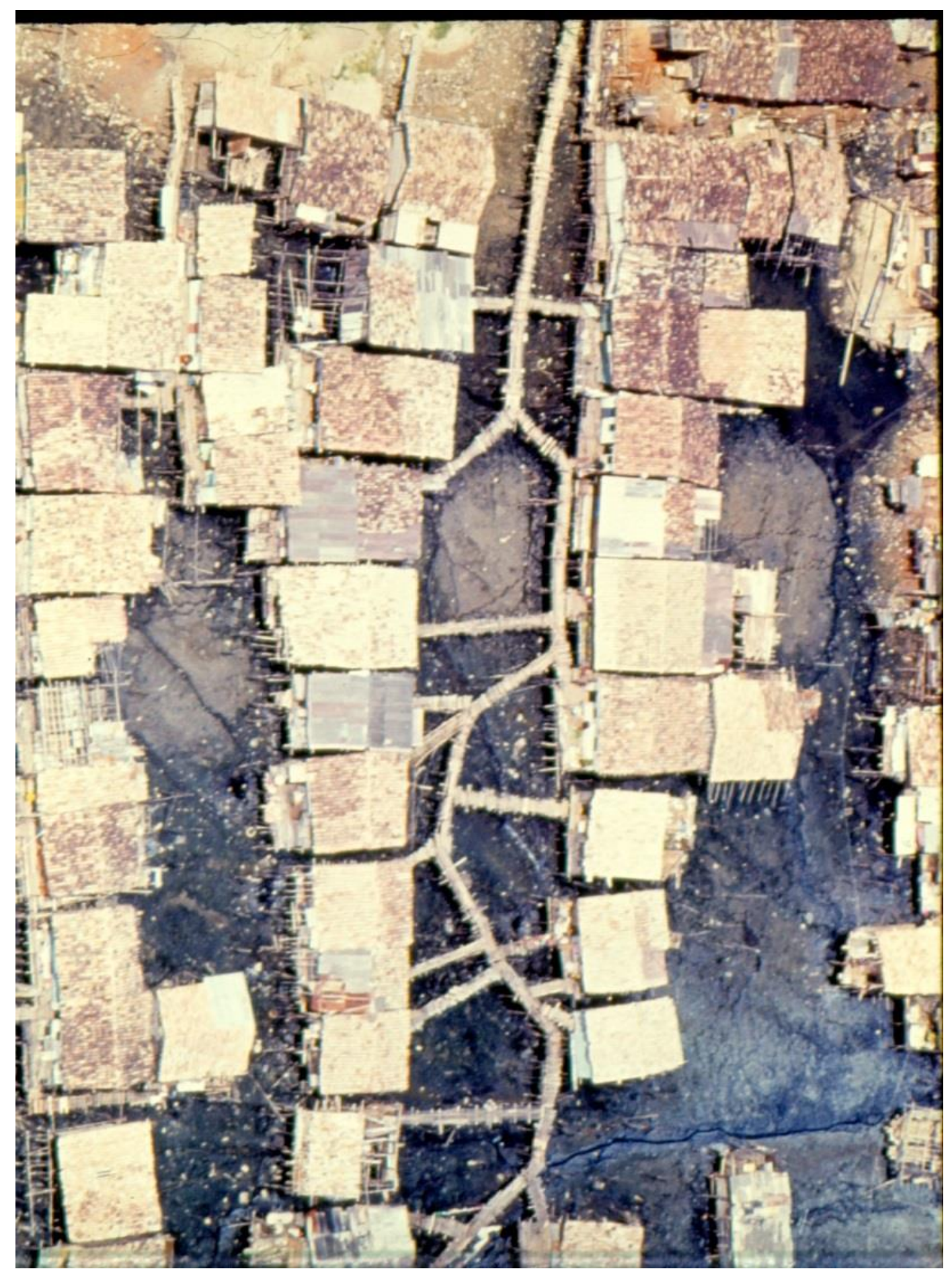

Foto 5: vista aérea da área de alagados na cidade Baixa em Salvador. Acervo Bahiatursa, 1980 


\section{REFERÊNCIAS DOS MOVIMENTOS DE RAFAEL SANZIO ARAÚJO DOS ANJOS - DÉCADAS 1970 -}

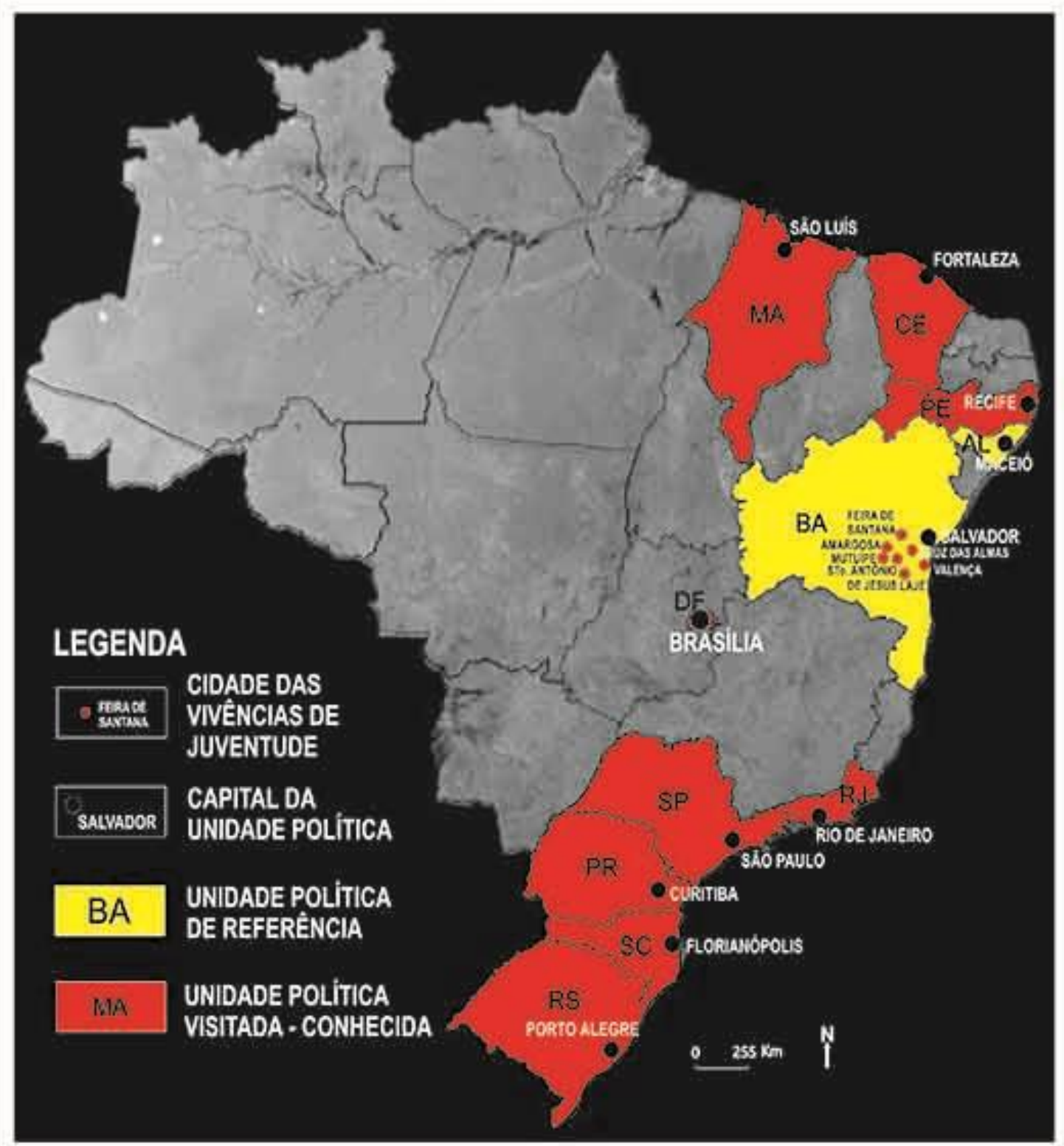

O Base Canogrifica IBGE - 2010 / tmagem de Satelite: Mosaico serai -controlado de Imagcte Landsal - Nusa - USA 2013 - Projeto Geogrifico e Cartográfico by Geog Rafoel Sanzio A, dos Anjes - Centro de Cantografia Apliçada e Informaç5o Geogrifíca - Lniversidade de Brasilia - Brasitia - DE. 2015. E-mailsquilombora unb.br / Tele: 55 (61) $3107-5242$

\section{Mapa 02}




\section{OS ANOS 1980: A FORMAÇÃO BÁSICA NA UFBa., OS TRABALHOS, OS PROJETOS E A OPÇÃO PELA ACADEMIA}

Como na Parte 1, a seguir estão as referências e os eventos significativos da minha trajetória geográfica e suas significações no tempo-espaço. Nesta Partedestacamos o seguinte:

1. O Diagrama da Etapa I retrata de forma esquemática os movimentos em torno do Curso de Geografia realizado na Instituto de Geociências da UFBa. (19781982), onde alguns aspectos já foram tratados no item anterior, mas outros também relevantes merecem referência. Por exemplo: Os estágios técnicos na CONDER (Companhia de Desenvolvimento da Região Metropolitana de Salvador) onde participei da montagem do Sistema de Informações GeográficasCartográficas Metropolitana usando fotografias aéreas coloridas para geração dos dados necessários para a construção dos mapas temáticos. Estas experiências me deram uma amplitude da segregação sócio-espacial e da "Salvador Africana" que não tinha tido ainda a dimensão da sua extensão geográfica. O outro estágio marcante é na Prefeitura de Salvador no Projeto Mamba (Mapeamento dos Sítios e Monumentos Negros na Cidade de Salvador) onde eu fui designado para realizar a cartografia propriamente dita dos dados sistematizados dos terreiros de matriz africana na cidade e realizar o cadastro de alguns sítios que posteriormente redundariam em áreas tombadas pelo IPHAN como: o Terreiro da Casa Branca e o Parque de São Bartolomeu (Subúrbio de Salvador). Ver em anexo uma cartografia moderna do terreiro da Casa Branca na Av. Vasco da Gama em Salvador;

2. O Trabalho Final na Cidade de Barreiras (mapeamento dos tipos de usos urbanos) e a constatação do potencial de mudança com a chegada da agroindústria (soja) foi um marco nas evidências de estudos geográficos aplicáveis. Sem utilizar produtos de Sensoriamento Remoto, mas apenas trabalho de campo, a cartografia do território urbano utilizado foi o principal produto do estudo. Logo após a Formatura (Bacharel em Geografia) sou contratado para a Consultoria Técnica da elaboração do Mapa Termoelétrico da Bahia a ser elaborado pela concessionária (Coelba); 
3. O convite para assumir um cargo de Geógrafo em Projeto do CNDU com recursos do Banco Mundial em Juazeiro - Bahia (Projeto Especial Cidades de Porte Médio), provoca a minha mudança da cidade de Salvador. Este trabalho me trouxe maturidade profissional na medida em que tive de coordenar equipes de campo e sistematizar base informacional de amplo uso na Prefeitura de Juazeiro. Esta experiência foi ampliada com as aulas que passei a ministrar no Curso Noturno de de Formação de Professores de Petrolina. Descobri uma vocação que não tinha experimentado ainda de ser professor de Geografia. Junto com a satisfação veio a contestação também da necessidade de estudar mais! Solicitei umas férias e fui a São Paulo para um curso no INPE (São José dos Campos) e uma vista a amigos em Rio Claro, onde me inscrevi num Curso de Especialização em Sensoriamento Remoto. Tinha claro comigo que queria estudar mais o uso e aplicação das imagens de satélite para ler-interpretar melhor o território e portanto, a representação cartográfica estar mais próxima do mundo real. Este era o fio condutor da decisão que iria tomar em seguida de pedir as contas na Prefeitura de Juazeiro para ir fazer a Pós-Graduação Lato Sensu na UNESP. Esta experiência me fortaleceu o caminho da instrumentação geográfica e também uma investida na educação com uma especialização;

4. O Diagrama da Etapa II (páginas 2 - 2 ) mostra na sua primeira parte o retorno para Salvador com atuação em trabalhos técnicos (Revisão do Plano Diretor do Polo Petroquímico de Camaçari); em educação com aulas no Depto. de Geografia da Universidade Católica de Salvador e junto ao Centro de Estudos Afro-Orientais da UFBa. (CEAO) ministrando disciplina como Geógrafo Jorge Conceição no Curso de Especialização "Introdução aos Estudos das Culturas Africanas" em parceria com a Prefeitura Municipal de Salvador. Esta experiência me conduz a elaborar um Projeto ligando a África-Brasil-EducaçãoGeografia-Cartografia e faço uma solicitação de apoio ao CNPQ; 


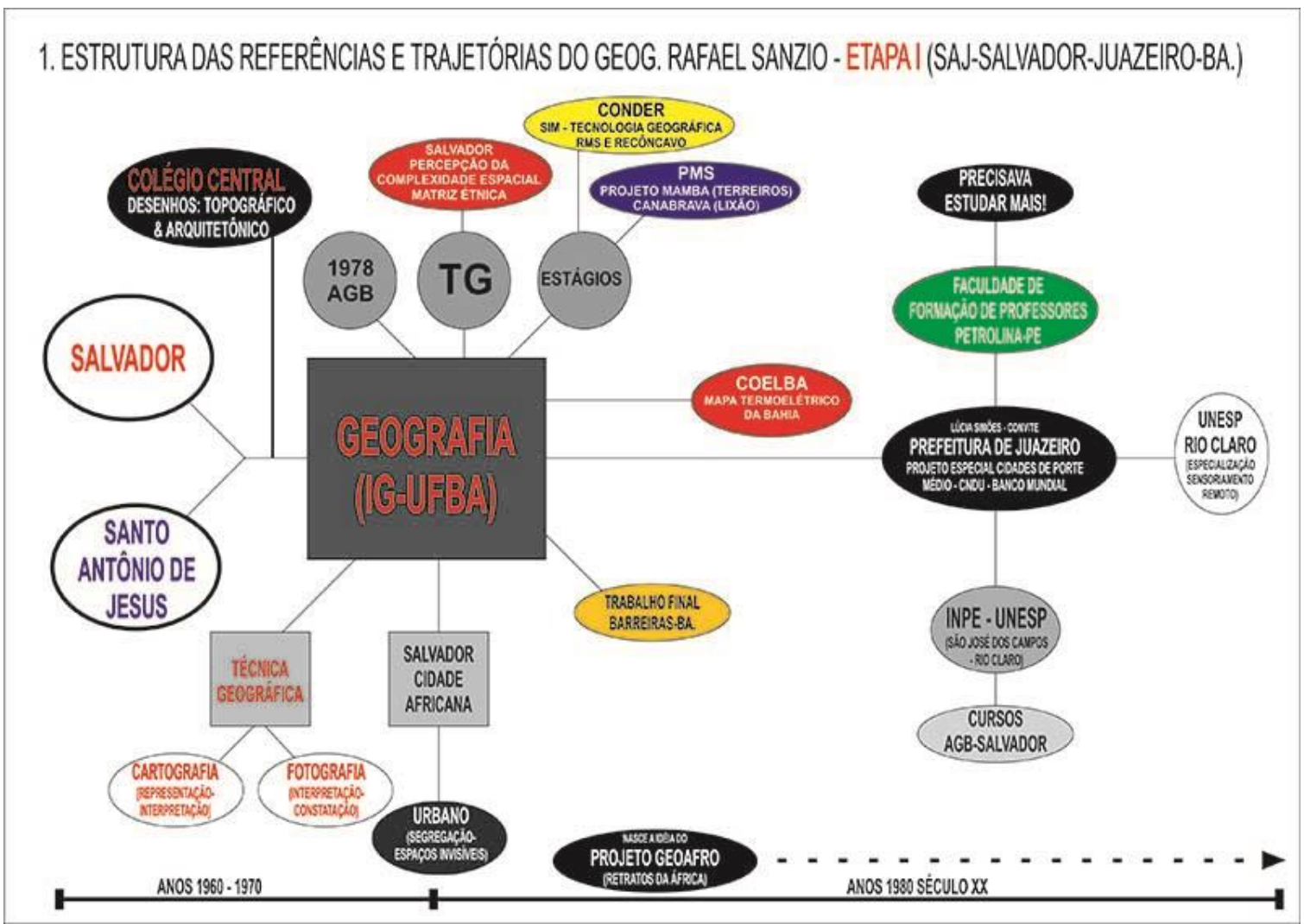

Diagrama 01

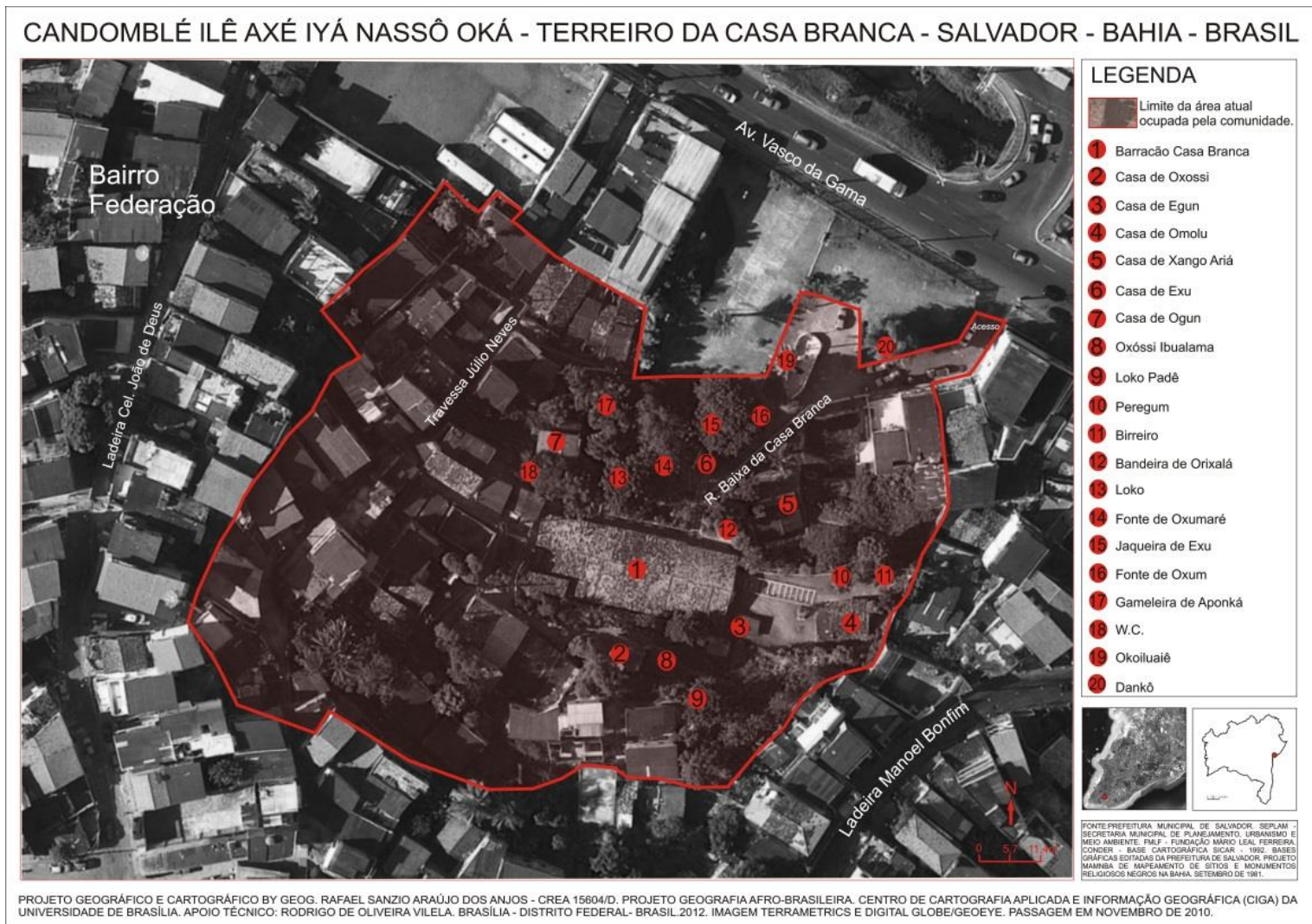

Mapa 03

Revista Eletrônica: Tempo - Técnica - Território, V.7, N.1 (2016), 1:76 ISSN: 2177-4366 
5. No fim dos anos 1980 recebo um convite para montar um Laboratório de Cartografia na Universidade de Brasília pelo colega geógrafo e amigo Neio Campos que estava em Brasília fazendo Mestrado. Resolvi fazer a seleção em Planejamento Urbano (FAU-UnB) e em paralelo implementar o Laboratório solicitado pela Profa. Ignez Barbosa (Chefe do Depto.). Deu certo o projeto do Mestrado, assim como o de Prof. Visitante em paralelo com as atividades de montagem do Lab. de Cartografia e Fotointerpretação. Verifiquei uma condição de trabalho e oportunidades que não tinha encontrado ainda e nesse contexto surgiu um concurso público na área de Cartografia e Fotointerpretação. Resolvi fazer o concurso e a perspectiva temporária que ainda eu tinha de ficar em Brasília foi alterada com esta ação;

No item a seguir trato da minha formação na Pós-Graduação (Mestrado e Doutorado) e os distintos projetos desenvolvidos. 


\section{REFEREANCIAS DOS DELOCAMENTOS DE RAFAEL SANZIO ARAÚJO DOS ANJOS - DÉCADA 1980 -}

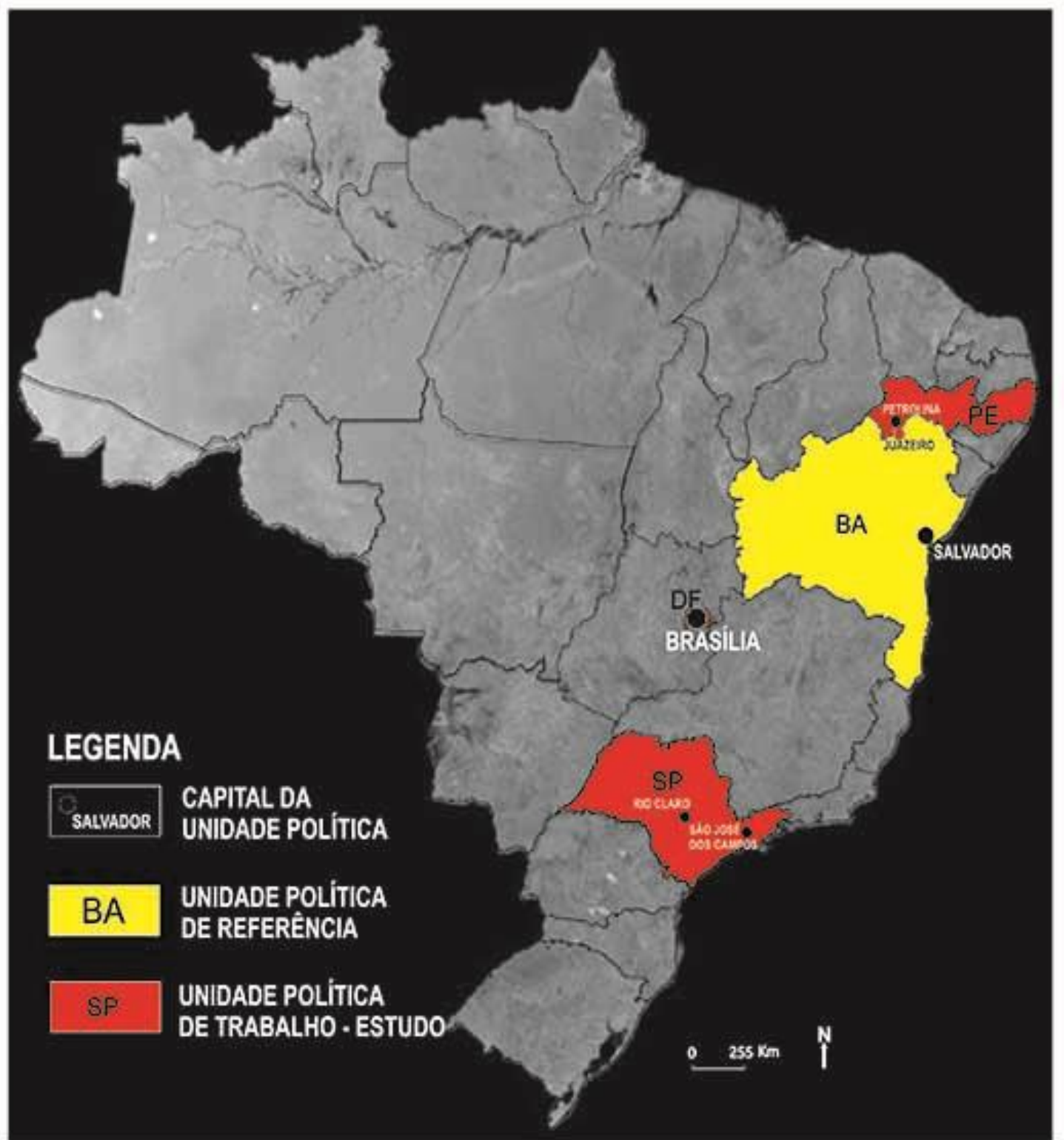

O Base Cantognífica IBGE . 2010/Imagem de Satelite: Mosaico semi -controlado de Imageris Landsat - Nasa - USA 2013 o Projeto Geográfico e Cartogrífico by Gcog. Rafoel Sanzio A. dos Anjos - Centro de Cartografia Aplicada e Informaça Gcografica - Universidade de Brasilia - Brasilia - DE. 2015. E-mailsquilombo/a unb.br/Tcle: 55 (61) 3107-5242

\section{Mapa 04}




\section{OS ANOS 1990-2000: O MESTRADO NA FAU, O DOUTORAMENTO NA POLIUSP-IRD, A EXPANSÃO DO PROJETO GEOAFRO, AS PUBLICAÇÕES E O PÓS- DOUTORAMENTO (MRAC-BE)}

1. Na UnB tive que equilibrar as atividades paralelas (disciplinas e pesquisa Mestrado, aulas das Disciplinas Instrumentais como Prof. Visitante e montagem do Laboratório de Cartografia e Fotointerpretação planejado). Neste sentido, busquei relacionar o conteúdo e práticas das disciplinas com a pesquisa em realização da Pós-Graduação (monitoramento do crescimento urbano com recursos de Sensoriamento Remoto). O meu orientador foi o Prof. Aldo Paviani que me trouxe mais conteúdo da Geografia Urbana particular do DF e nas análises dos produtos cartográficos. Um dos avanços foi a constatação que o monitoramento espacial possibilita a leitura de tendências de crescimento que poderão se consolidar ou não. Trabalhei nesta direção e a Dissertação de Mestrado já incorporou a configuração dos Vetores de Expansão da Grande Brasília;

2. Paralelo a todas estas atividades tive o Auxílio solicitado ao CNPQ para o Projeto GEOAFRO (Retratos da África) aprovado e com isso tive recursos para aprofundar e elaborar produtos do estudo. $\mathrm{O}$ auxílio concedido possibilitou aprofundar o conhecimento da cartografia Temática básica do continente africano e a constatação da inexistência de uma abordagem condizente nos livros didáticos em uso nos distintos níveis educacionais. Esta constatação do processo de trabalho deu impulso ao comprometimento educacional que passaria a ser crescente no referido Projeto. Os resultados culminaram em uma exposição na Biblioteca Central da UnB e o artigo de capa da Revista Humanidade No. 22 (Editora UnB); 


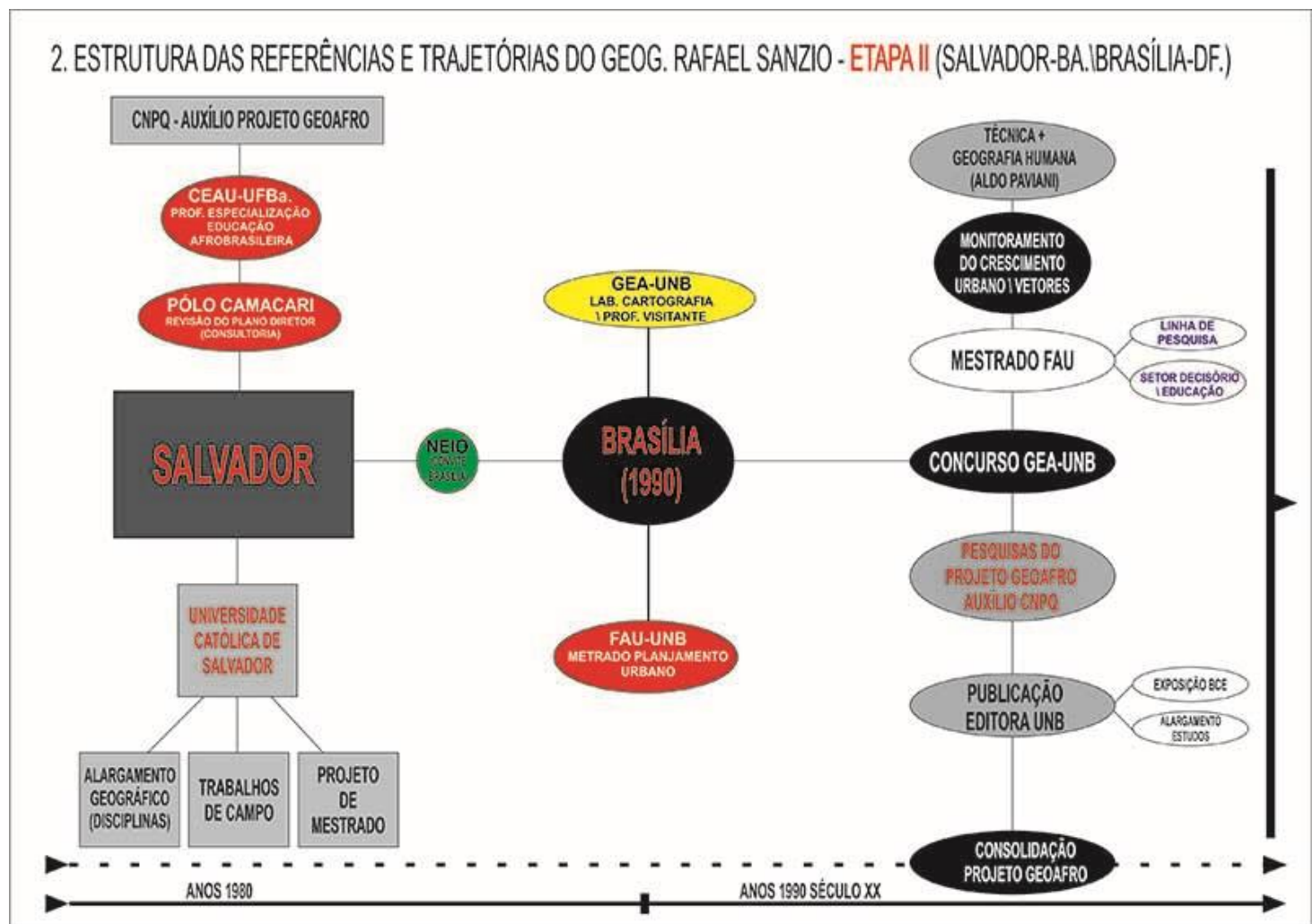

Diagrama 02

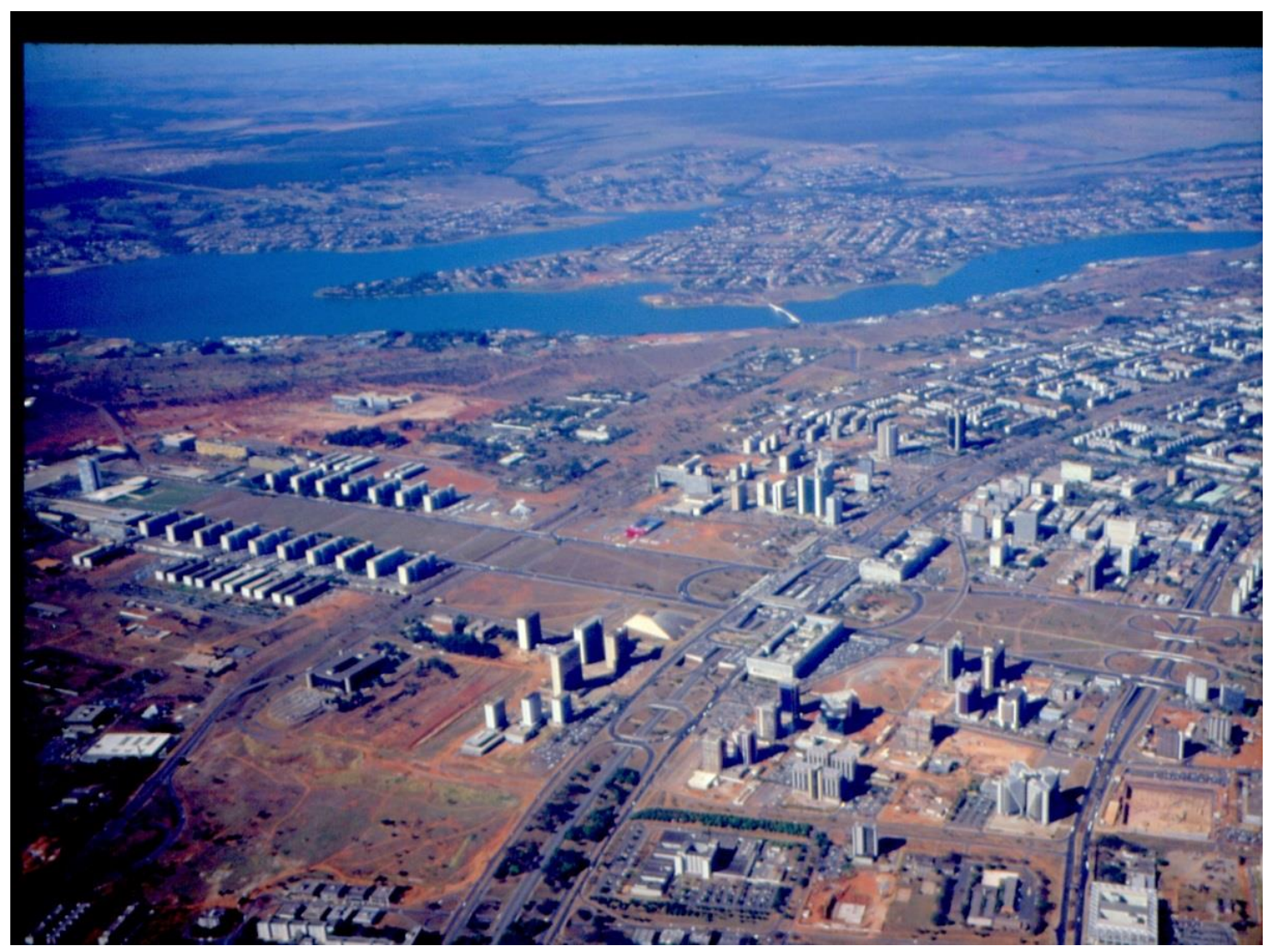

Foto 06: Vista aérea panorâmica do centro do Plano Piloto de Brasilia. Registro de helicóptero por Rafael Sanzio, 1992. 
3. Em 1992 faço a seleção e passo para o Doutorado em Informações Espaciais no Depto. de Enga. de Transportes da POLIUSP. Algumas experiências relevantes nesse período: A. Ser orientado inicialmente por um Prof. Empresário dono de uma empresa de consultoria técnica me deu uma dimensão dos diálogos necessários entre a academia e o setor privado. Mas a pesquisa tomou força quando o Co-orientador (Prof. Jorge Dantas FAU-USP) passou a ser o orientador oficial; B. O Lab. de Geoprocessamento do Programa Pós da POLIUSP recebia sistemáticas demandas e algumas delas de cunho bem geográfico foram relevantes como a solicitação da Prefeita Luiza Erundina para a criação de um Sistema de Informações Automatizado que mostrasse o nível de infraestrutura da periferia de São Paulo, para onde estava direcionada a sua gestão. O período de estadia em São Paulo foram durante os anos 1992 e 1993. Em 1994 fui para Paris e Montpellier para complementação da pesquisa e fazer parte do Grupo de Pesquisa do IRD (antiga Orstom) e Maison da laGeographie (Montpellier);

4. A tese que modelou a estrutura urbana da grande Brasília para o ano 2000 foi muito bem aceita por vários setores e com várias formas de produtos (jornal, livro, exposição, consultoria técnica, etc). A vivência na França me revelou uma africanidade dos espaços e da sua população que me era desconhecida até então. Os séculos de dominação colonial e imperial evidenciava já um certo "retorno" na grande metrópole francesa e no interior. Esta visão me trouxe uma necessidade de alargar o Projeto GEOAFRO incorporando uma linha de pesquisa mais consistente na Cartografia da Diáspora Africana no Globo (passado e presente) e outra no mapeamento dos registros dos territórios dos antigos quilombos existentes no Brasil; 


\section{REFERÊNCIAS DOS MOVIMENTOS DE RAFAEL SANZIO ARAÚJO DOS ANJOS - DÉCADA 1990 -}

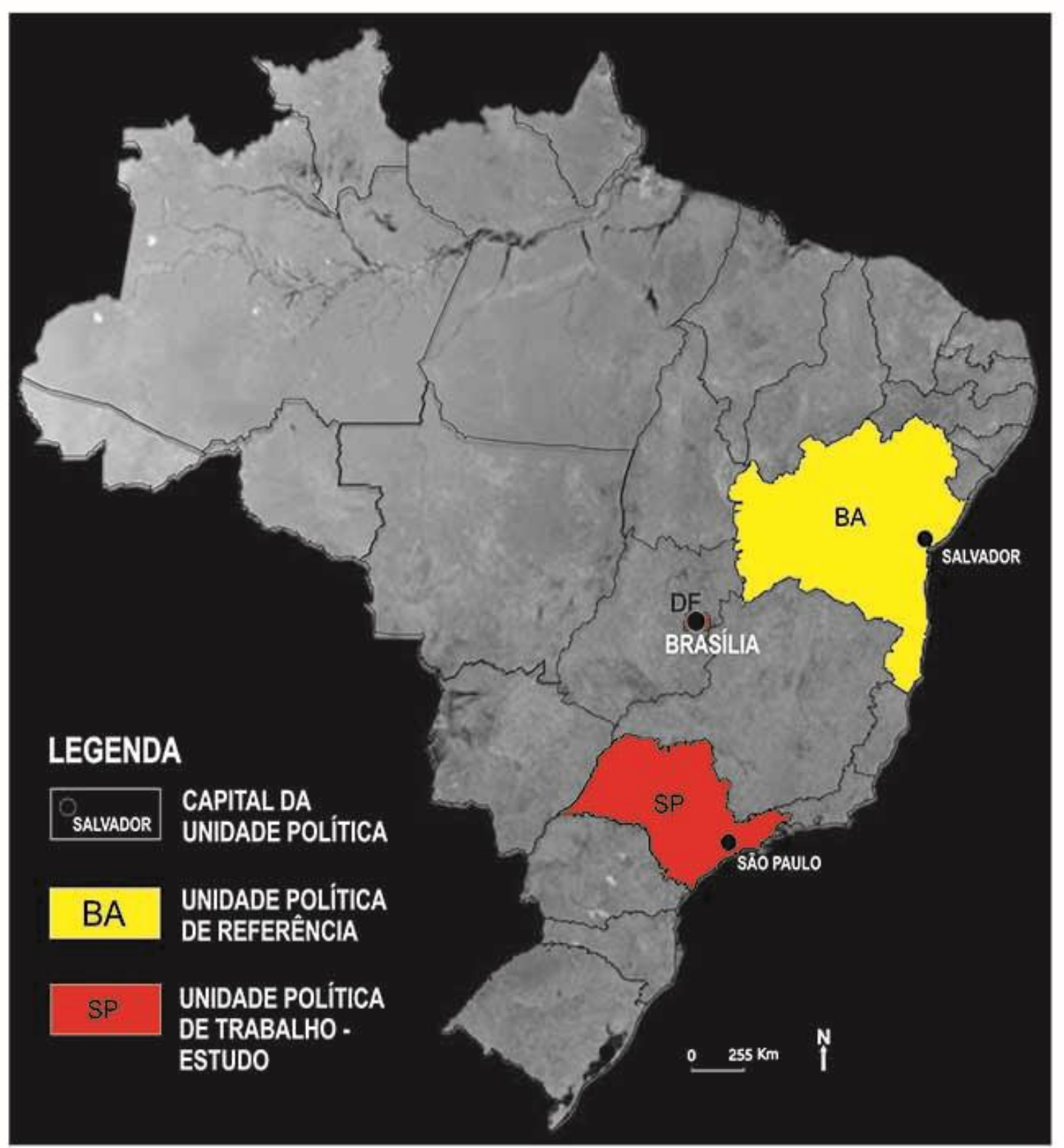

O Base Cartográfica IBGE . 2010 / Imagem de Satélite: Mosaico semí-controlado de Imagens Landsat - Nasa - USA 2013 6. Projeto Geográfico e Cartográfico by Geog. Rafael Sanzio A. dos Anjos - Centro de Cartografia Aplicada e Informaçào Geográfica - Universidade de Brasilia - Brasilia - DF. 2015. E-mail:quilombo@unb.br / Tele: 55 (61) 3107-5242

Mapa 05 
5. A Linha de Pesquisa da Cartografia dos Quilombos Contemporâneos do Brasil resultou numa parceria com a Fundação Cultural Palmares - Ministério da Cultura no fornecimento de informações e elaboração de mapas temáticos para subsidiar ações governamentais (reconhecimento e titulação de territórios). Deste processo de trabalho foram organizadas duas publicações: o livro Territórios dos Antigos Quilombos do Brasil e o material didático - Coleção África-Brasil: Cartografia para o Ensino-Aprendizagem (2000) que fizeram parte de exposições no Salão Negro do Ministério da Justiça e da Câmara dos Deputados em Brasília. Vários artigos e capítulos de livros foram escritos e publicados de diversos temas do Projeto GEOAFRO.

6. Em 2005 uma oficina temática para professores organizada pela SECAD MEC foi ministrada em sete capitais do Brasil (Salvador, Maceió, Brasília, Belo Horizonte, Rio de Janeiro, São Paulo, Porto Alegre) e em paralelo com esta atividade foi realizado uma exposição temática nos Conjuntos Culturais da Caixa Econômica Federal. O Ministro Gilberto Gil nos fez um convite para levar a exposição ao Ano do Brasil na França. Realizamos a mostra em outubro/2005 na Maison duBresil da CitéUniversitaire em Paris. Este alargamento do Projeto GEOAFRO e seus produtos fortalecem as pesquisas, adquirem mais respeitabilidade na academia e no setor decisório, assim como junto a mídia; 


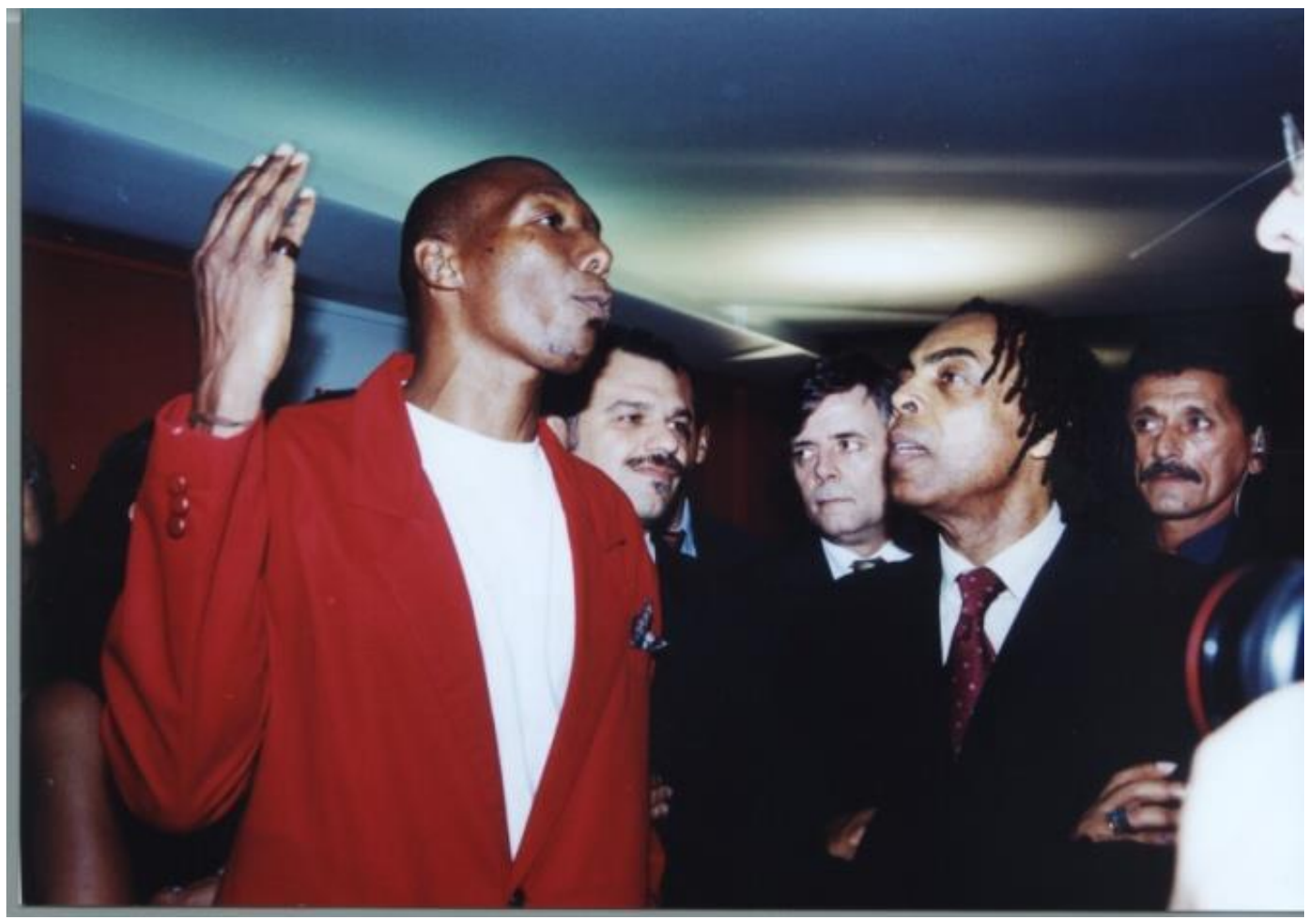

Foto 7: O geog. Rafael Sanzio com o ministro Gilberto Gil na abertura da exposição "cartografia dos quilombos contemporâneos" na câmara dos deputados. Brasília, 2003

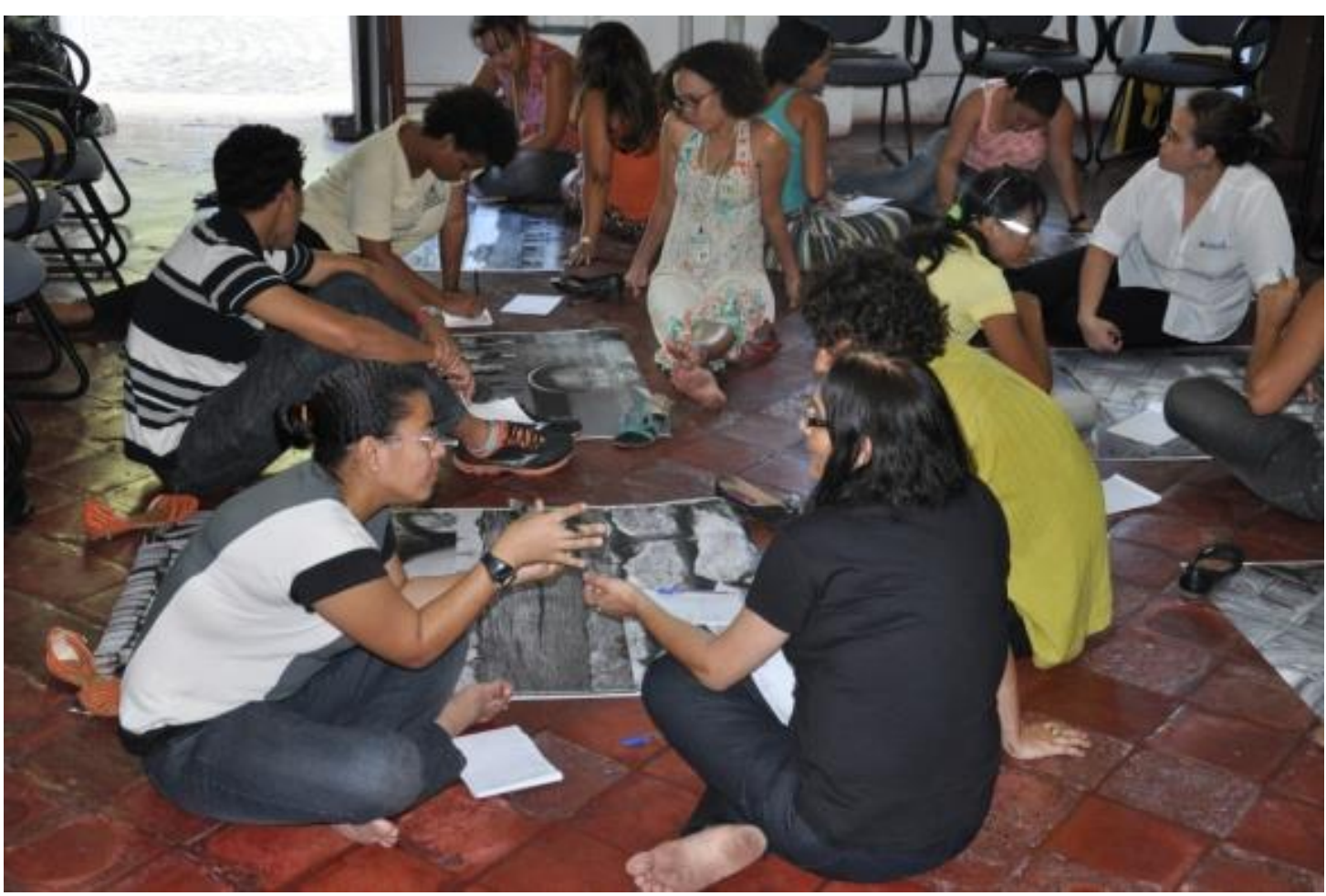

Foto 8: Registro de dinâmica de trabalho da oficina temática: Quilombos - Heranças Geográficas. Rafael Sanzio, recife, 2005 
7. O Projeto do Crescimento Urbano de Brasília passa a ser denominado "Dinâmica Territorial no Brasil Central" no sentido de alargar a região de pesquisa e os tipos de estudos direcionando-se para uso do território território usado. Alguns capítulos de livros são publicados em obras organizadas pelo Prof. Aldo Paviani (Coleção Brasília - Editora UnB), assim como a edição e publicação de um material didático (Geografia do Distrito Federal - Cartografia para Educação), assim como exposições temáticas e o livro Dinâmica Territorial: Cartografia - Monitoramento - Modelagem (2008);

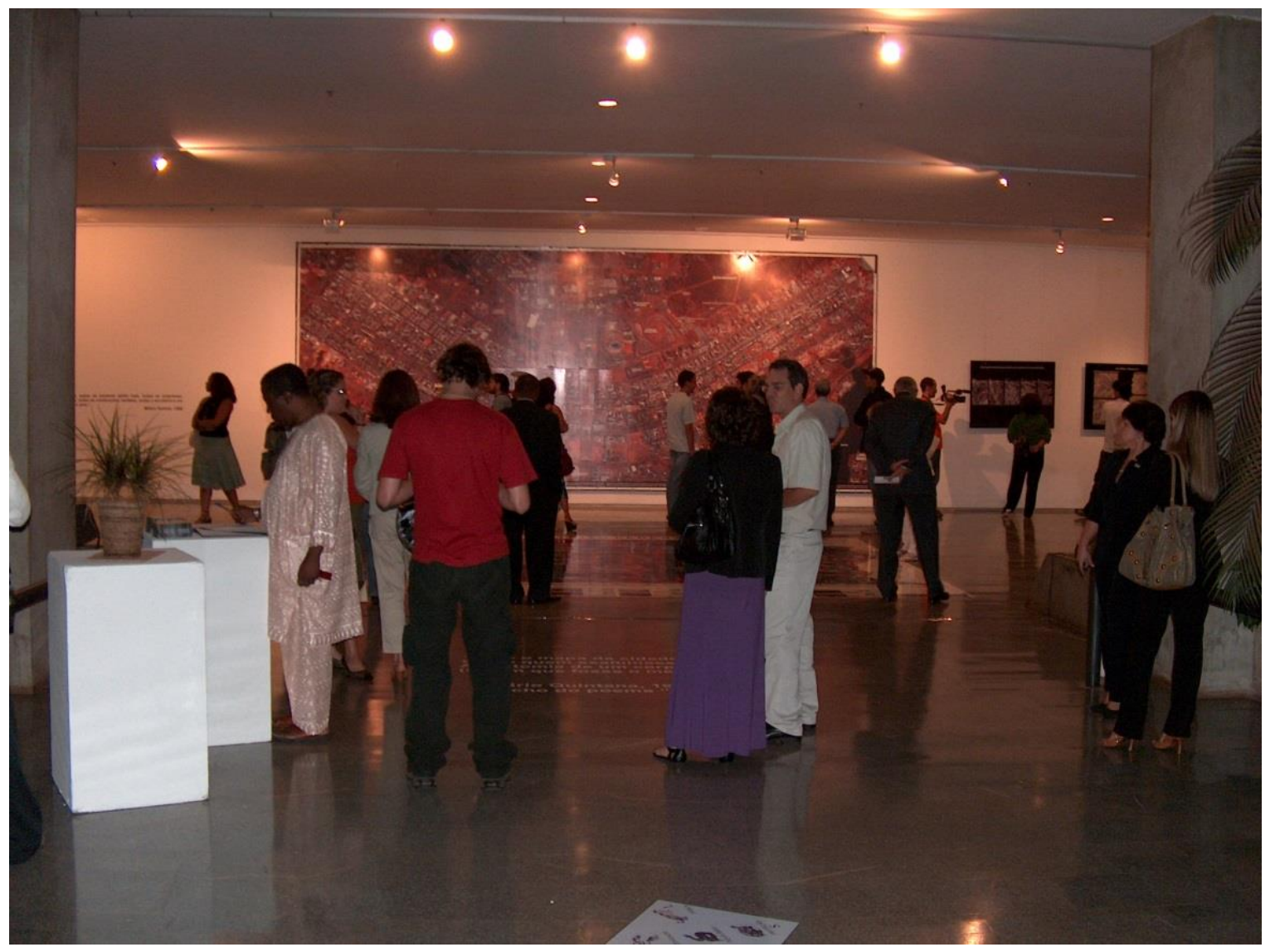

Foto 9: Registro da exposição Brasília: Tempo - Espaço - Território no Teatro Nacional de Brasília. Rafael Sanzio, 2007

8. Dois Projetos em parceria como CIGA são relevantes neste período que reque uma grande capacidade organizacional: o Mapeamento do Uso da Terra da Região Sul da Bahia para a Empresa TCBR. Uma equipe de estudantes é alocada para este trabalho e cumprimos os prazos sem comprometimento das agendas acadêmicas. Outra atividade foi a parceria com a FUNAI na elaboração da cartografia do Atlas bilíngue da Grande Área Kaiapó (Mato 
Grosso - Pará). O produto foi elaborado nas línguas tradicionais e português do Brasil, assim como as cartografias produzidas-desenhadas pelos povos da grande área e a oficial. Uma outra parceria importante foi a elaboração da pesquisa, do livro e da exposição "Quilombolas - Tradições e Cultura da Resistencia" desenvolvida pela AORI Comunicações com Pesquisa de minha autoria e Fotografias de Andre Cypriano;

9. Em 2006 fiz uma visita técnica ao Museu Real da África Central na localidade de Tervuren na periferia de Bruxelas. O Projeto do Pós-Doutorado foi apresentado ao CNPQ e em agosto de 2007 fiz a mudança para desenvolver a pesquisa de elaboração do Atlas Afrobrasileiro. Os estudos programados para um ano se estenderam e tiveram o apoio institucional do MRAC por mais alguns meses (final de 2008) e suporte para um trabalho de campo na República Democrática do Congo e em Angola. Os resultados do processo de trabalho foram muito além dos programado e pelo menos cinco publicações foram planejadas das pesquisas realizadas no Pós-doutoramento. Foi publicado a primeira obra em 2009 o livro: Quilombos: Geografia Africana Cartografia Étnica - Territórios Tradicionais (parceria do CIGA-UnB/Mapas Editora \& Consultoria/CESPE-UnB);

10. O retorno do Pós-Doutoramento ao Departamento de Geografia ocorre em um momento de uma solicitação relevante do Colegiado: me atribuem a operacionalização como novo Coordenador do Programa de Pós-Graduação de rever o curso de Mestrado e implementar o novo curso de Doutorado. Paralelo a operacionalização do Doutorado foi criado e equipado o Centro de Documentação Milton Santos, instituído no regimento do PPGGEA-UnB constituído pelos seguintes componentes: sala de alunos com equipamentos; sala de aula para 25 alunos; acervo das teses, dissertações e monografias de graduação do GEA-UnB; Mapoteca e Acervo de periódicos. Todos estes componentes em um único espaço e funcionando bem! O Curso de Doutorado foi aprovado pela Capes em 2012 e alguns alunos já defenderam as suas teses. As outras obras programadas e publicadas estão tratadas no item a seguir. 


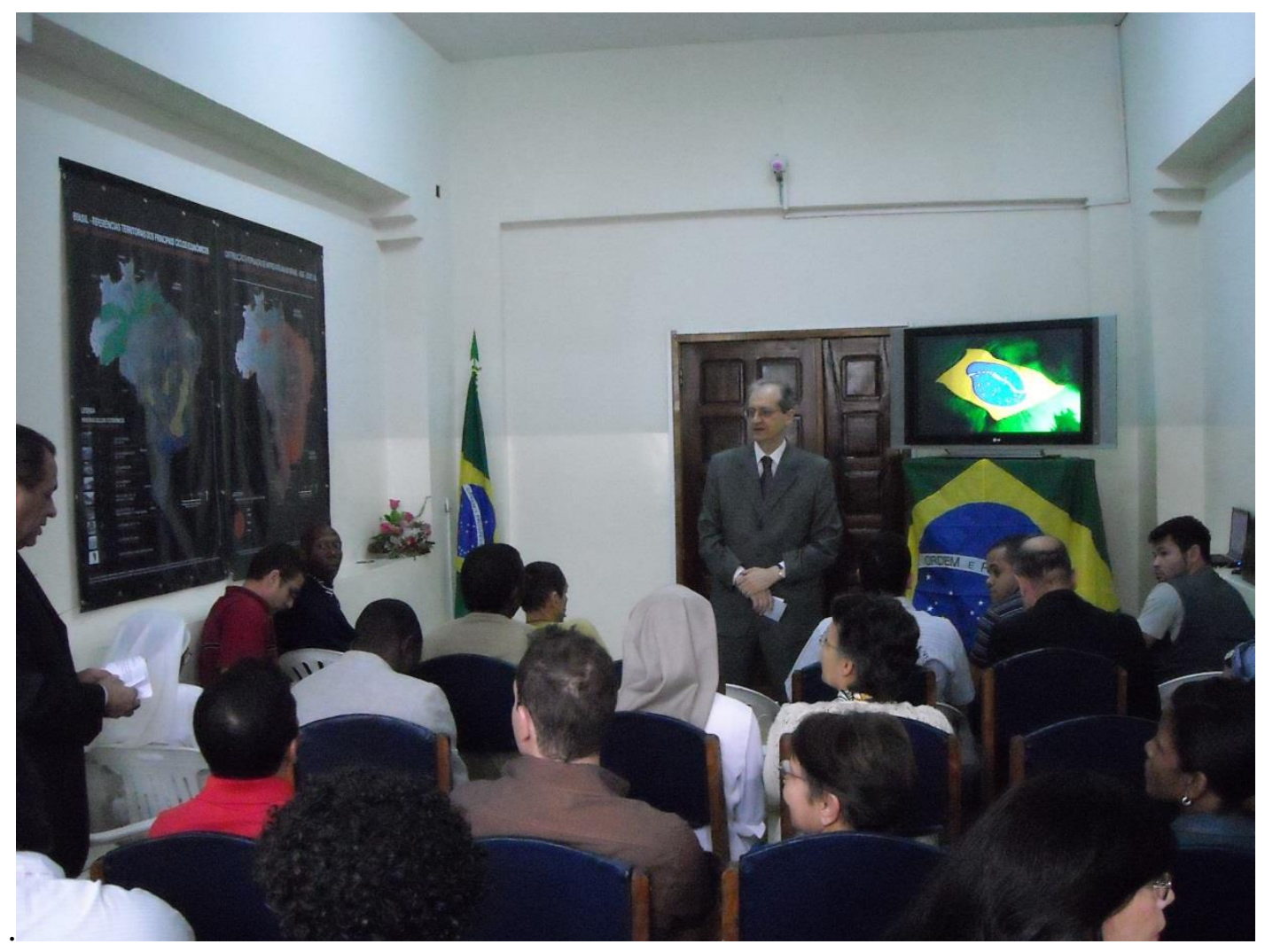

Foto 10: Registro da palestra proferida na embaixada do Brasil em kinshasa - rdc. Visita técnica do pós-doutoramento, 2008

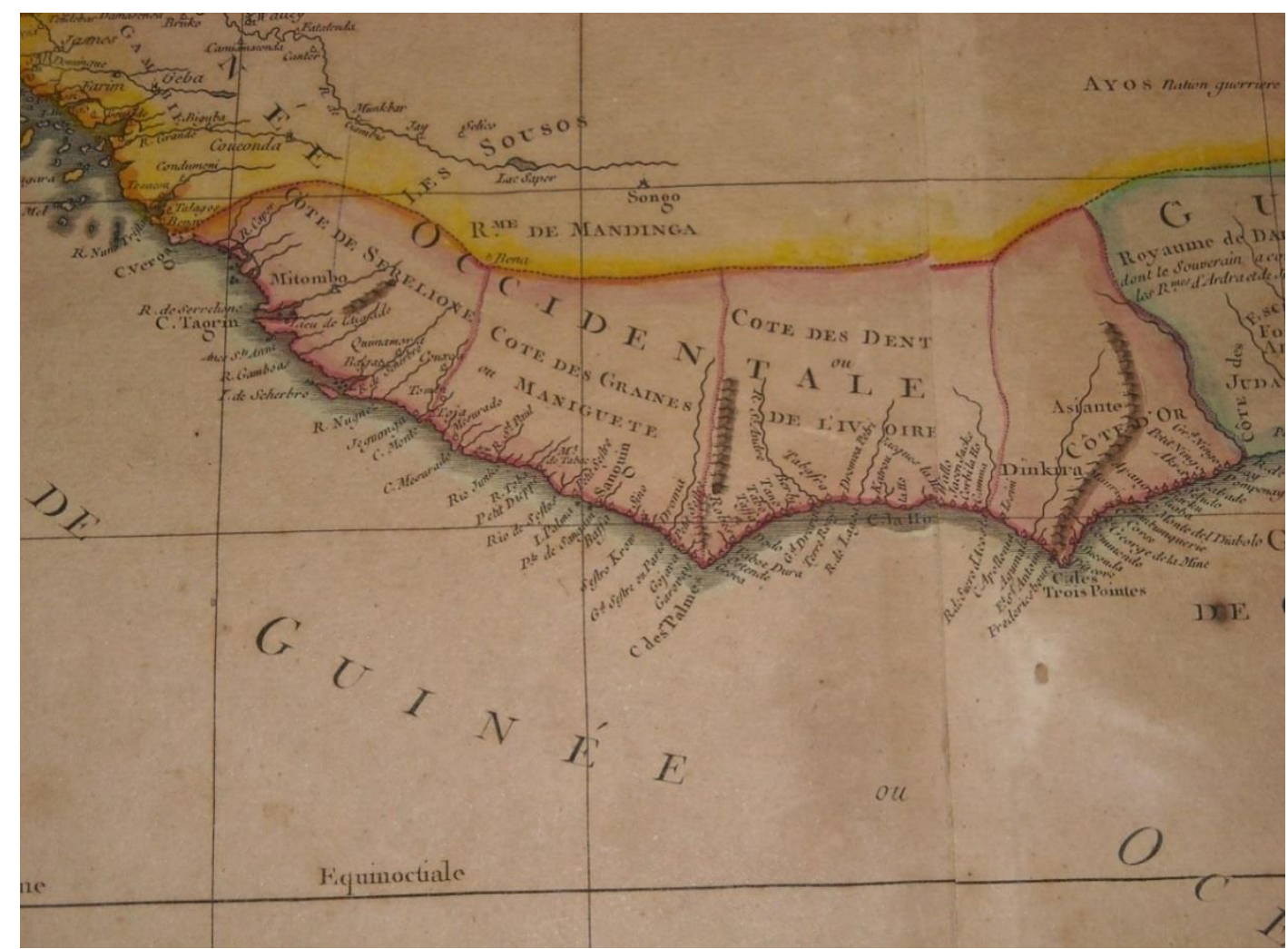

Mapa 07: Detalhe de cartografia antiga da região da costa da Guiné. Arquivo público de Angola. $\mathbf{s} / \mathbf{d}$ 


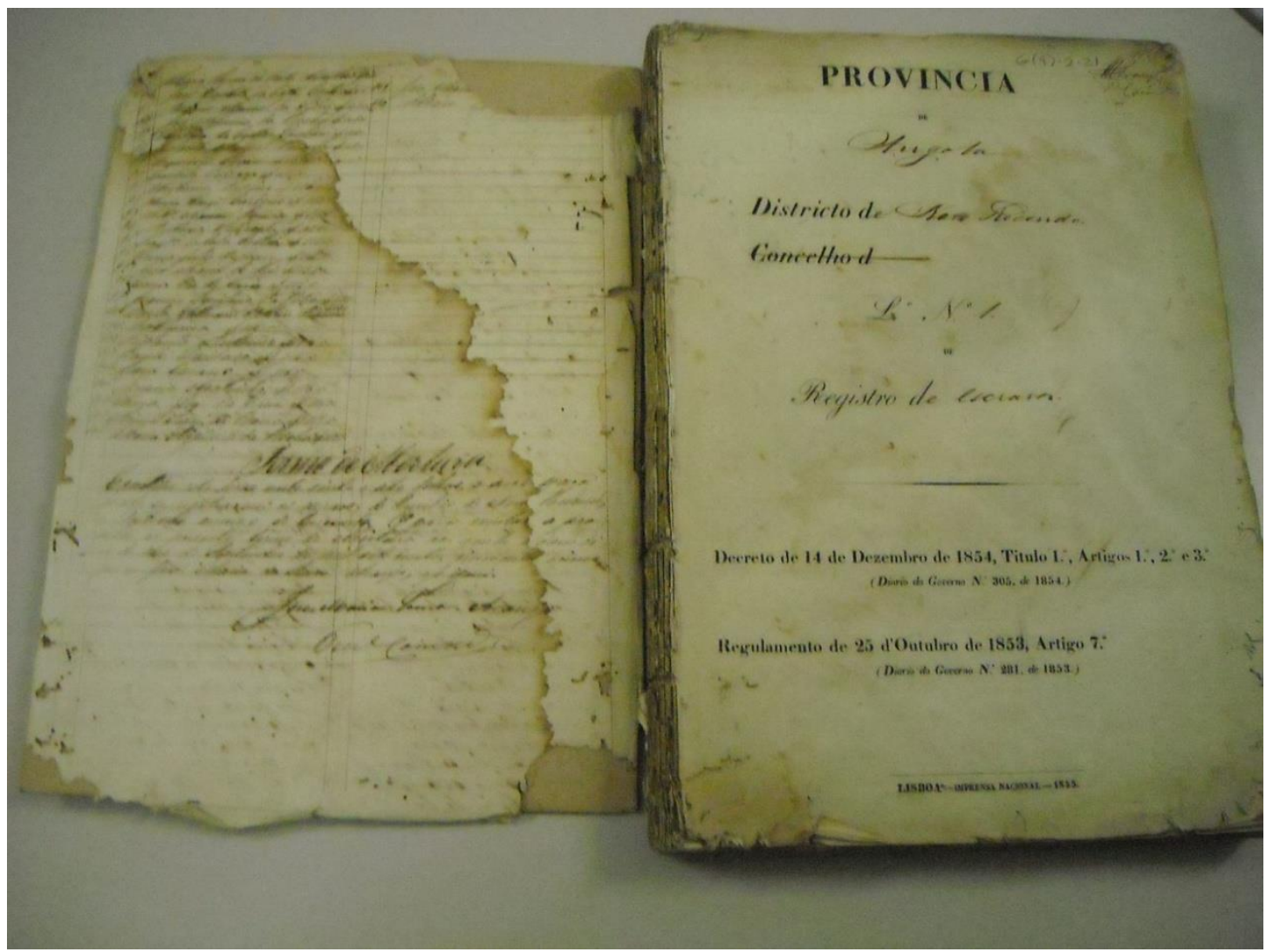

Foto 11: Detalhe de livro de registro de seres humanos africanos escravizados. Arquivo público de Angola. Séulo xviii

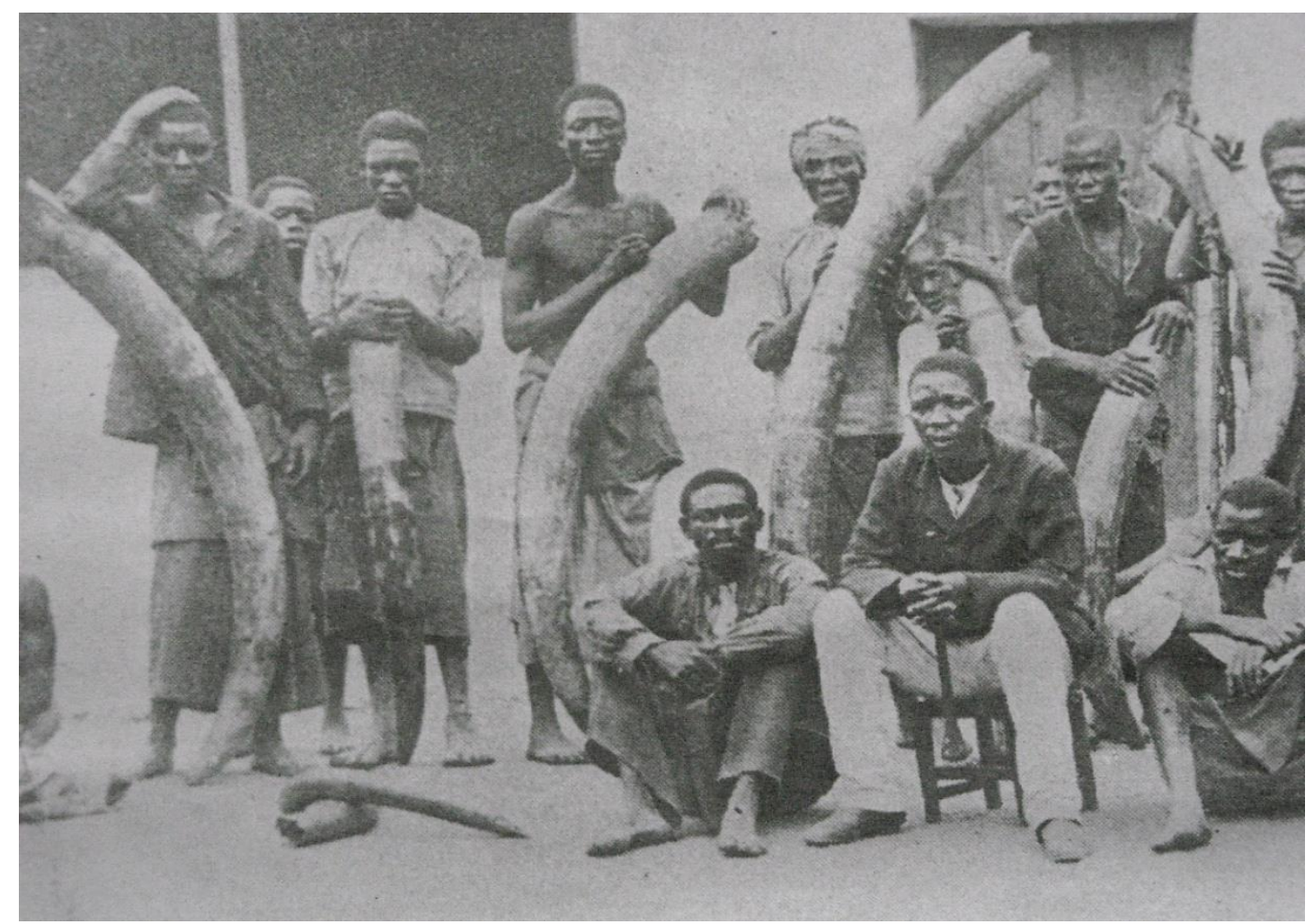

Foto 12: Anônima: grupo de trabalhadores Bantus da região de Angola. Século xix. Coleção arquivo hist'co de Angola. 


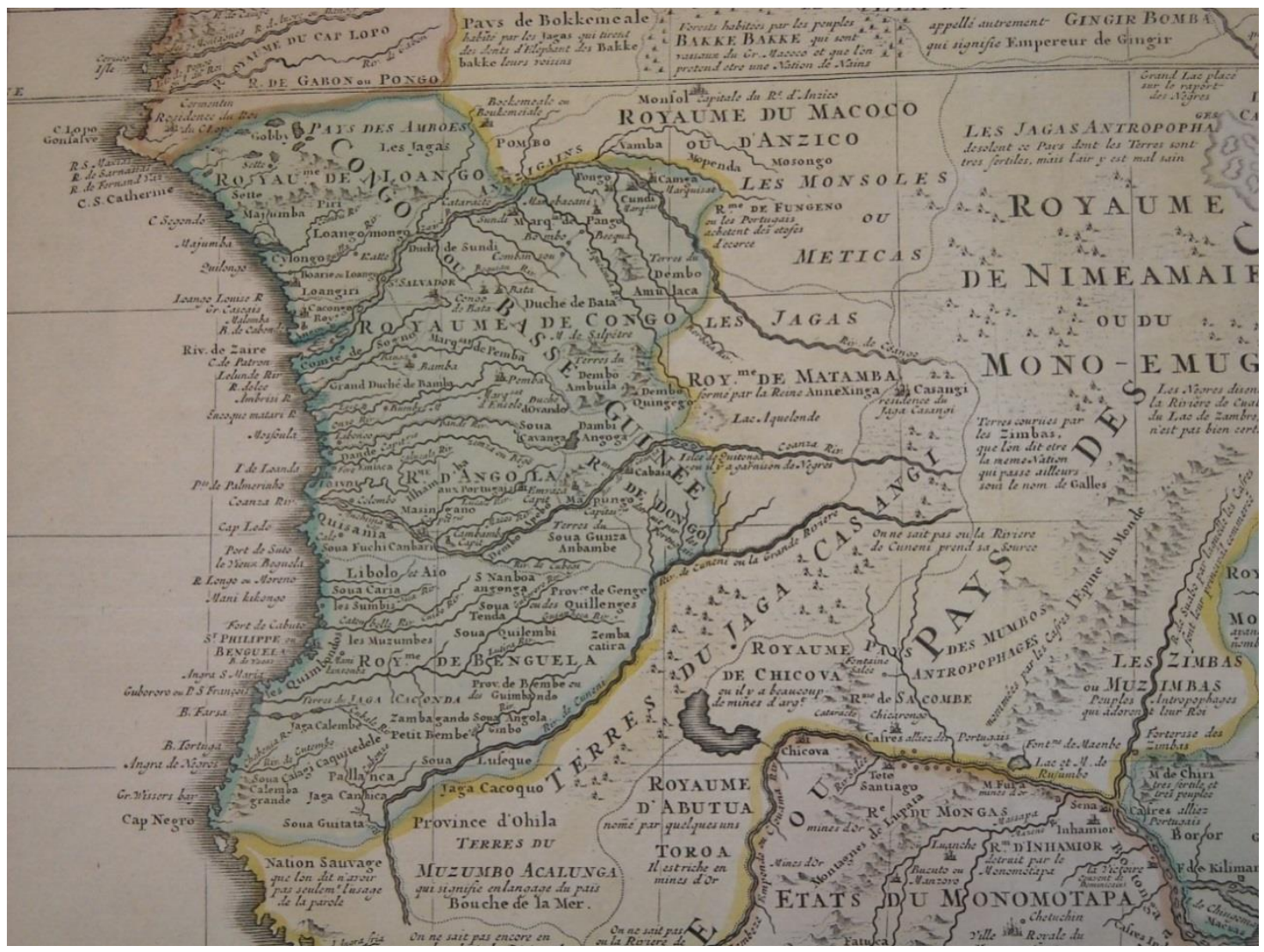

Mapa 08: carta: Detalhe de cartografia da costa dos antigos reinos de Baza Congo (São Salvdor) e Angola (Ngola). Acervo arquivo público de Angola. S/d

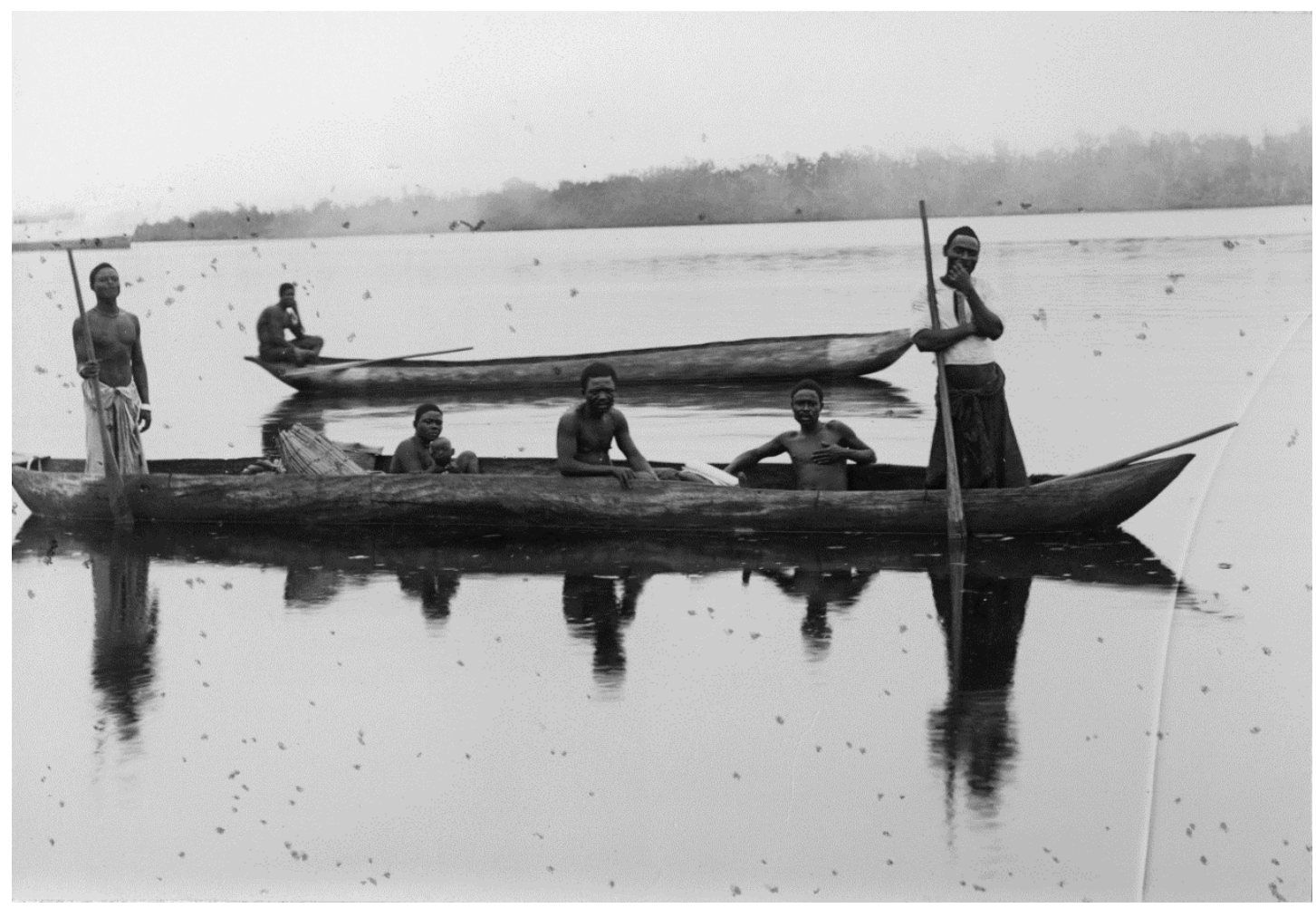

Foto 13: Anônima: grupo de homens Bantus na região do baixo congo. Início do século xx. Coleção mrac- 


\section{OS ANOS 2010. AS PUBLICAÇÕES DE CONSOLIDAÇÃO DO PROJETO GEOAFRO, O FORTALECIMENTO DO GRUPO DE PESQUISA, DO PPPGEA E DO CIGA-UNB}

1. Esta década se inicia no movimento das ações dos anos anteriores. Exposições temáticas tendo como base de pesquisa o livro Quilombos: Geografia Africana Cartografia Étnica - Territórios Tradicionais (capa dura e brochura, 2009) são realizadas em Luanda - Angola a convite da Embaixada do Brasil e em Brasília no Museu da República com apoio do Setor Cultural da Petrobras. Ambos os eventos alcançam o público desejado de professores e estudantes dos diferentes níveis de ensino em visitações monitoradas por estudantes treinados para os atendimentos;

2. Em 2011 é publicado o segundo livro oriundo das pesquisas do Pós-Doutorado: Territorialidade Quilombola: Fotos \& Mapas (português e inglês) e o mesmo tem o seu lançamento e divulgação comprometida por uma inundação que ocorre na UnB onde parte das publicações que tinham sido entregues dias antes ficou comprometida. Este fato ambiental mostrou a fragilidade dos espaços do sub-solo da UnB, do acervo do Depto. de Geografia e da integridade física dos seus professores e funcionários. Neste desastre o Centro de Documentação Geográfica Milton Santos também foi destruído;

3. Em 2013 é publicado o material didático cartográfico: Geopolítica da Diáspora África-América -Brasil: Séculos XVI-XIX. A segunda edição foi publicada em 2014 junto com mais duas outras obras: o Atlas Geográfico ÁFRICABRASIL e o Material Didático: O Brasil Africano: Cartografia para Educação (Mapas Editora \& Consultoria, 2014). Com isso já são cinco publicações oriundas das pesquisas aperfeiçoadas durante o pós-doutoramento. 


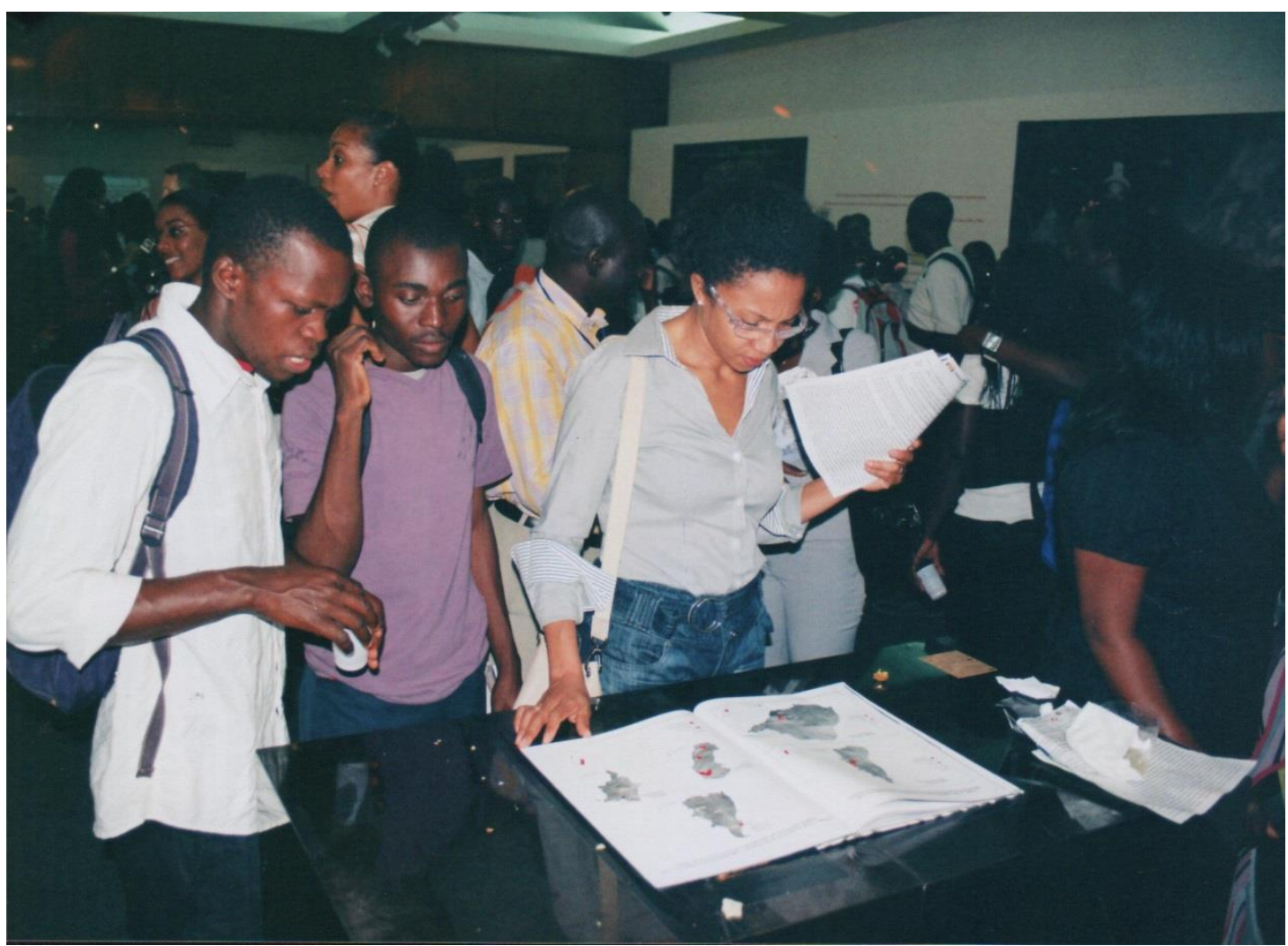

Foto 14: Abertura exposição Brasil Africano em Luanda - Angola. Novembro 2009, Rafael Sanzio

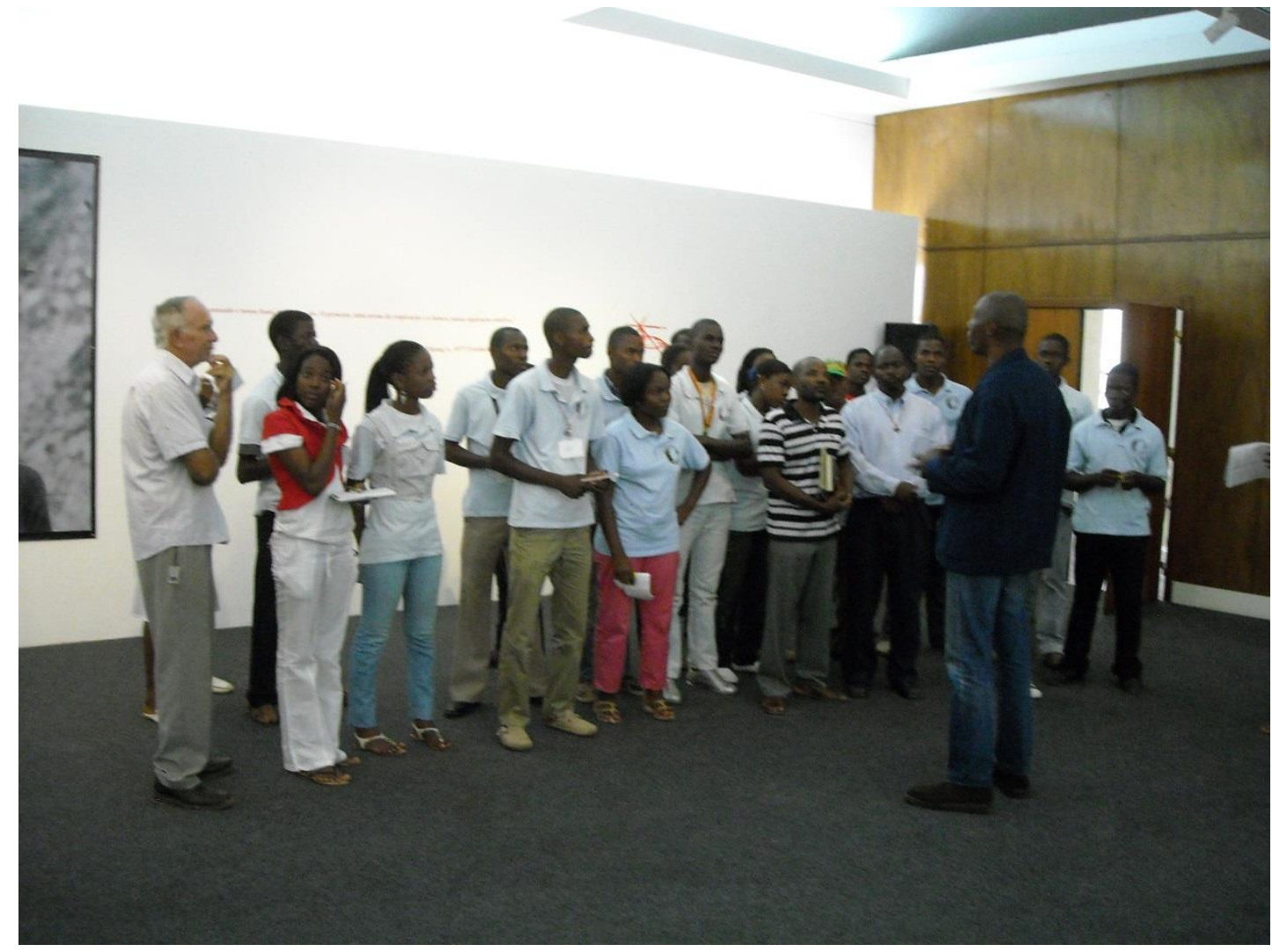

Foto 15: Visitação de alunos de ensino médio na exposição Brasil africano em Luanda - Angola. Maria Paula 


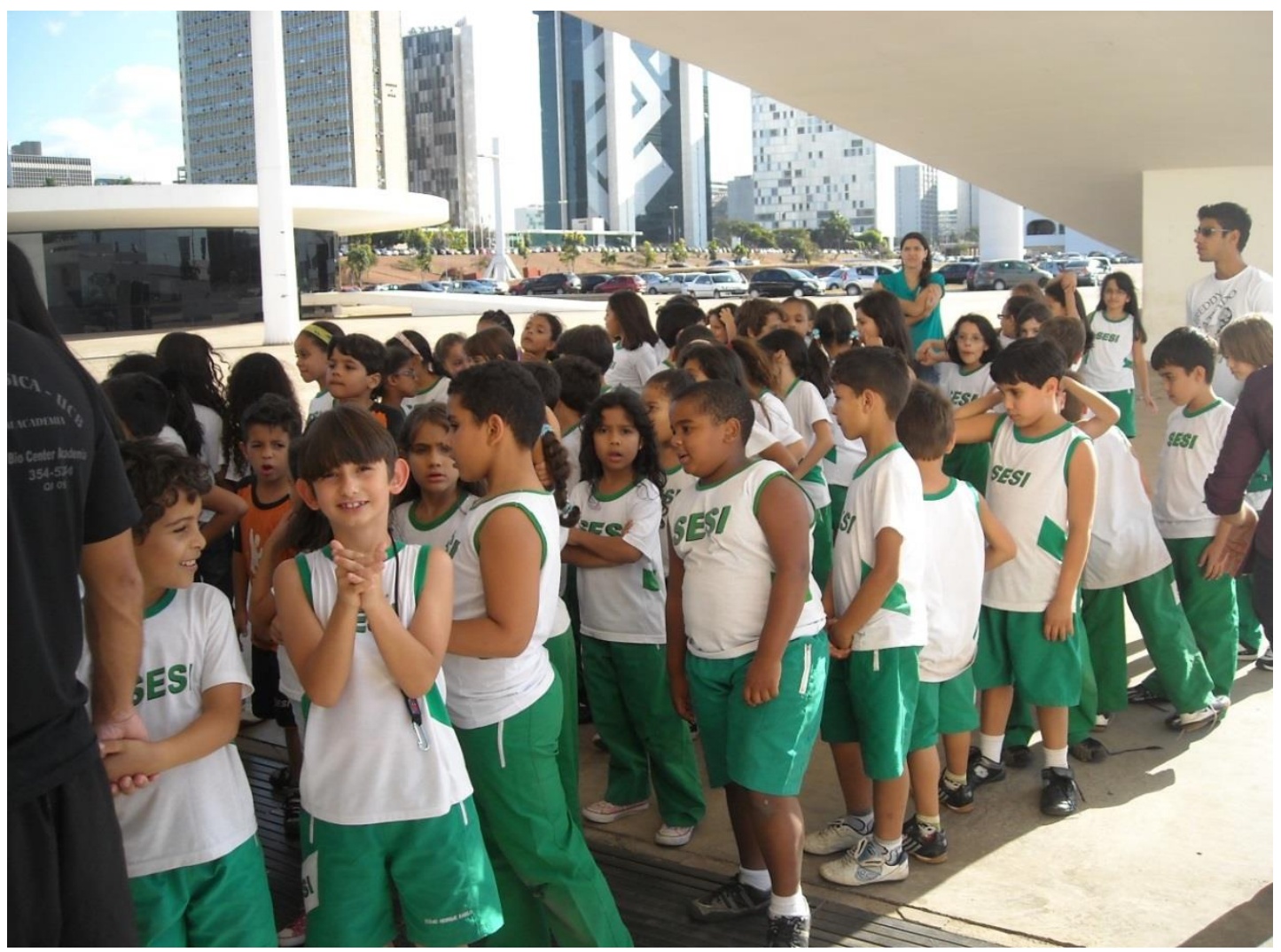

Foto 16: Visitação de alunos de ensino fundamental na Exposição Brasil Africano no Museu Nacional em Brasília. 2010. Geog. Rafael Sanzio

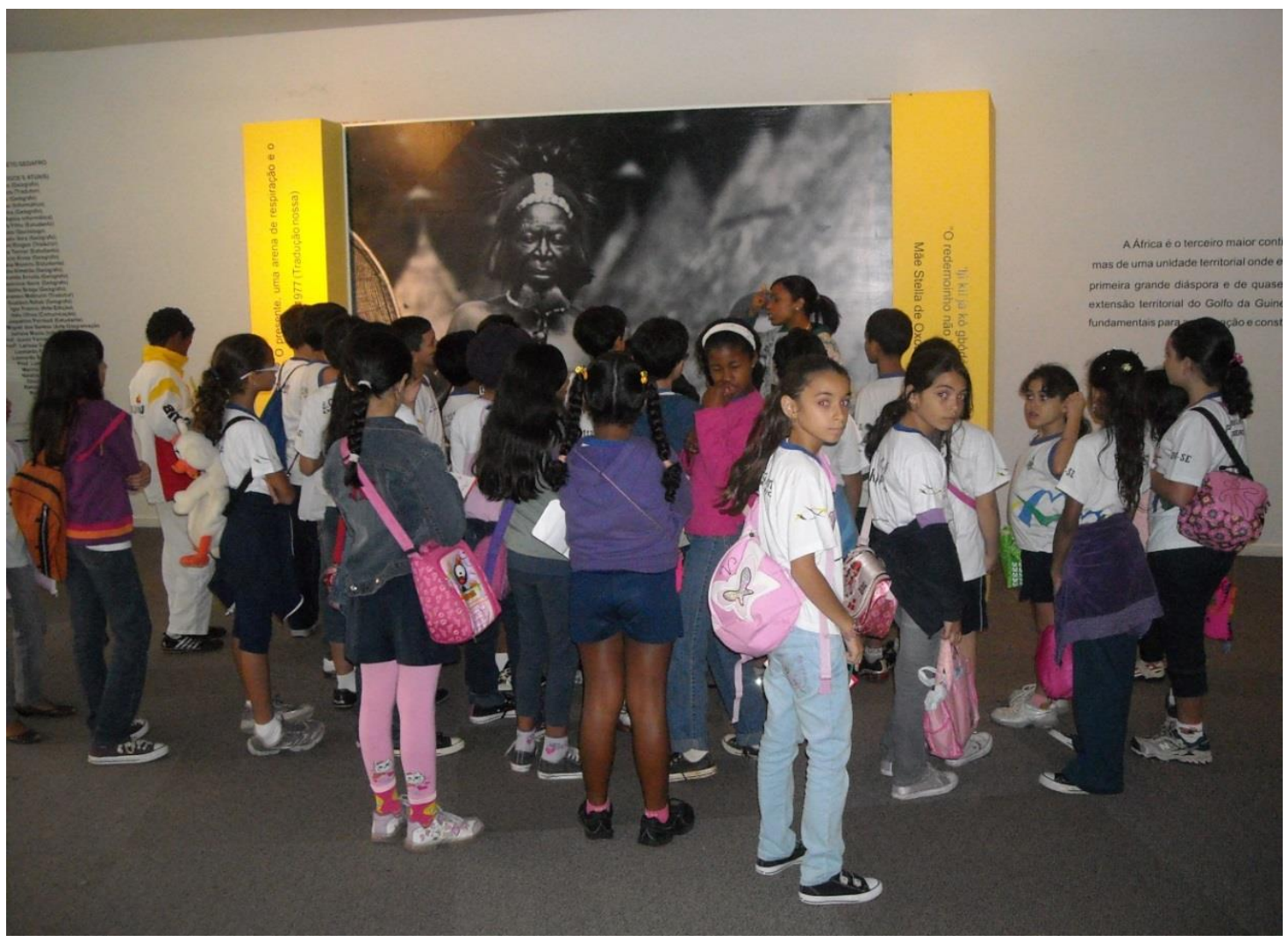

Foto 17: Visitação de alunos de ensino fundamental na exposição Brasil Africano no Museu Nacional em Brasília. 2010. Geog. Rafael Sanzio 
3. ESTRUTURA DASREFERENCIASE TRAJETÓRIAS DO GEOG. RAFAEL SANZIO-ETAPAIII (BRASILLA.DFISÄO PAULO.SP.PARIS.MONTPELLLER-FR.)

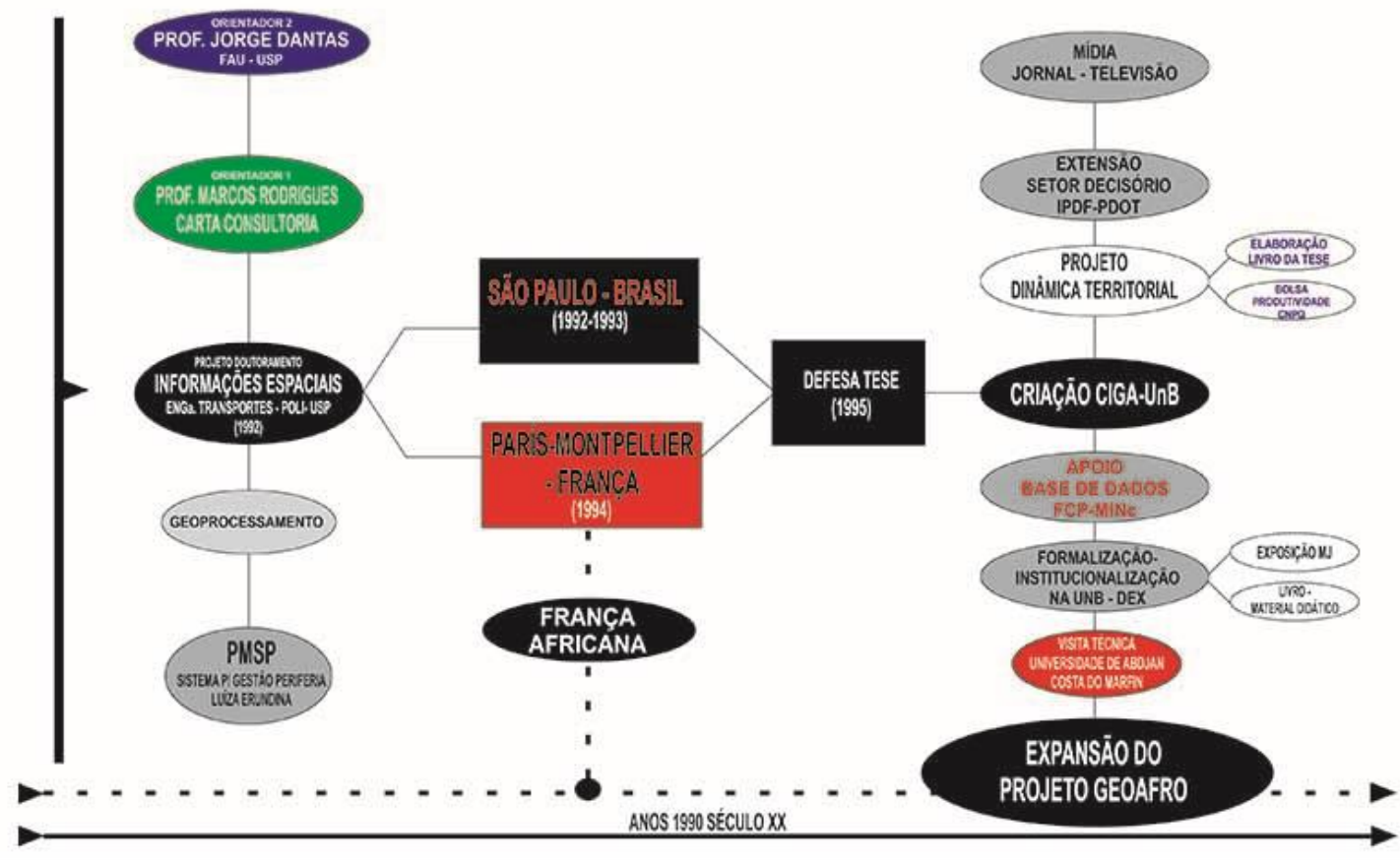

\section{Diagrama 04}

4. ESTRUTURADASREFERÉNCIASE TRAJETÓRIAS DOGEOG. RAFAELLSANZIO- ETAPAN (EXPANSÄO TERRTORIAL NACIONAL E NTERNACIONAL)

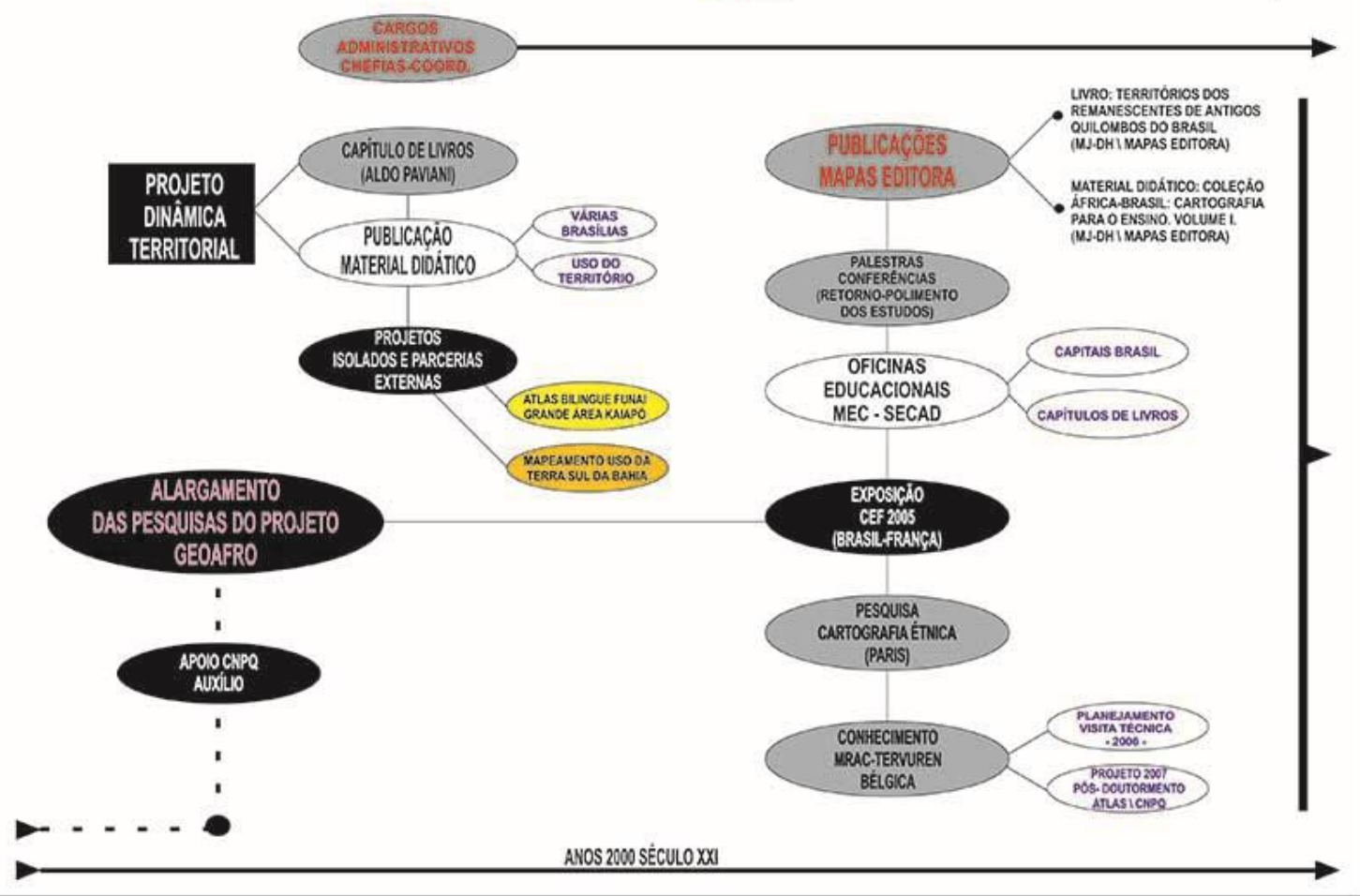

Diagrama 05 


\section{AS PESQUISAS BÁSICAS, OS PROJETOS ESTRUTURAIS, OS CONCEITOS E OS RESULTADOS: UM BREVE BALANÇO}

1. A DINÂMICA TERRITORIAL URBANA DA GRANDE BRASÍLIA, $O$ AMBIENTE VULNERÁVEL E AS TENDÊNCIAS ESPACIAIS

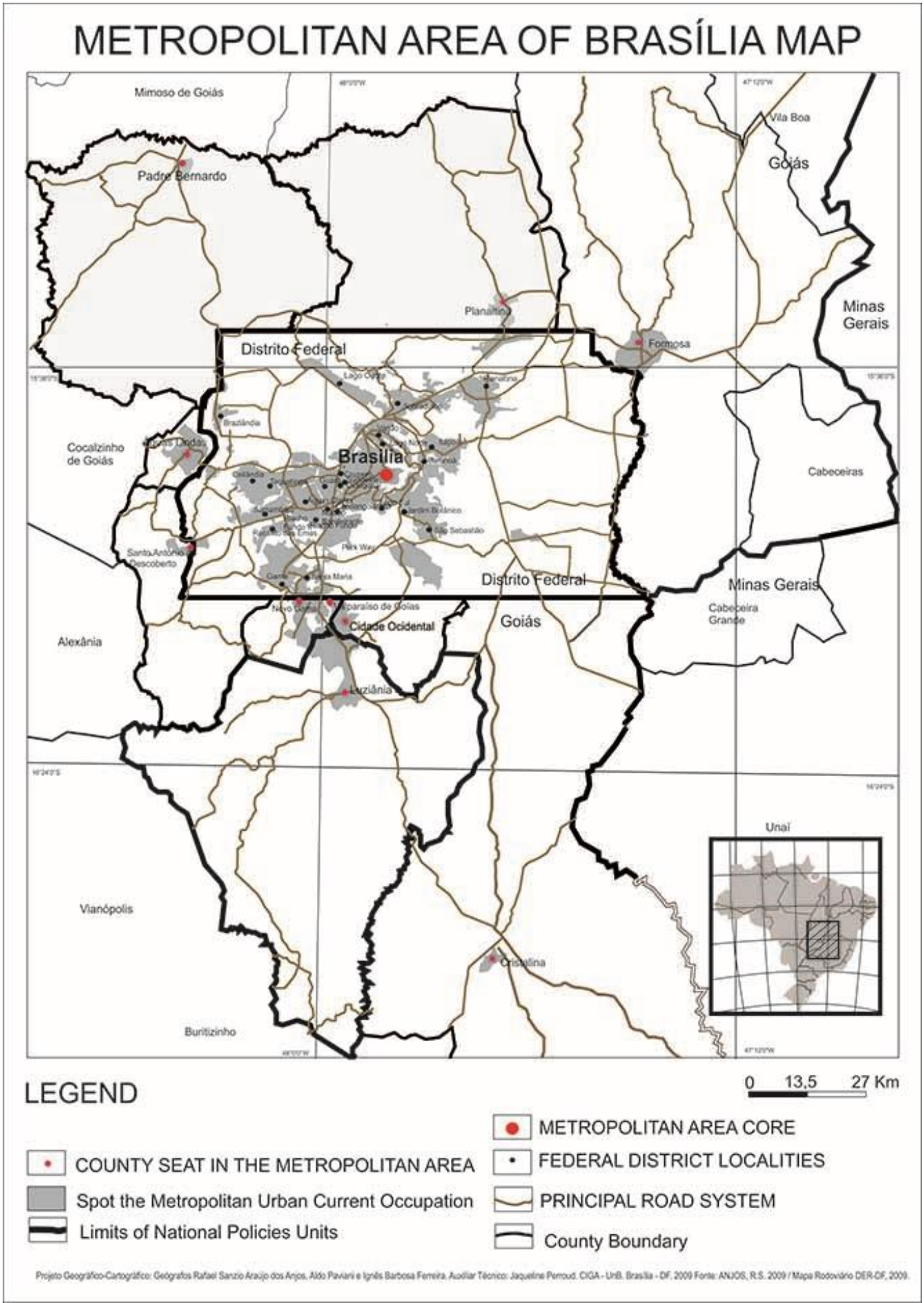

Mapa 10

Revista Eletrônica: Tempo - Técnica - Território, V.7, N.1 (2016), 1:76 ISSN: 2177-4366 
A terra, o território e a territorialidade assumem grande importância dentro da temática das mudanças e alterações nos espaços nacional, regional e local. Preconizamos que é possível representar e interpretar graficamente as espacialidades configuradas ao longo do tempo e apontar as suas tendências e restrições físicoambientais. Preconizamos que a geografia é a ciência da dinâmica do território e este, componente fundamental num sentido amplo, continua sendo o melhor instrumento de observação do que aconteceu, porque apresenta as marcas da historicidade espacial do que está acontecendo, isto é, tem registrado os agentes que atuam na configuração geográfica atual e o que pode acontecer, ou seja, é possível capturar as linhas de forças do movimento espacial e apontar as possibilidades da estrutura do espaço no futuro próximo.

Por outro lado, as demandas para a compreensão e resolução das complexas questões da dinâmica da sociedade são crescentes e a cartografia constitui um dos instrumentos melhor colocado para responder e informar com maior seriedade o que aconteceu, o que está acontecendo e o que pode acontecer com o território. Nesse sentido, as representações do processo de monitoramento do território, os produtos de sensoriamento remoto de última geração (imagens de satélite, principalmente), assim como as modelagens gráficas do território (cartografia de síntese), constituem um conjunto de ferramentas geográficas fundamentais para investigações dessa natureza. Estas possibilitam revelar graficamente o que acontece na dinâmica do espaço e tornamse cada vez mais imprescindíveis por constituírem, sobretudo, uma ponte entre os níveis de observação da realidade e a simplificação, a redução, a explicação e de pistas para a tomada de decisões e soluções dos problemas (ANJOS, 1992). Buscamos tratar o espaço urbano numa perspectiva dinâmica, onde tomamos como referência o crescimento da cidade, um dos componentes básicos da urbanização. É um processo espacial com dimensão temporal, onde a compreensão da atualidade integra as mudanças do passado e o potencial de variações para o futuro próximo.

Dessa maneira, entendemos a dinâmica territorial como um conjunto de eventos interconectados e estabelecidos, onde as suas interações refletem a estrutura da realidade. Ainda que a expansão das periferias urbanas seja, num nível geral, uma característica comum à maioria das cidades brasileiras, e que possa ser explicada, ela não forma um todo homogêneo. Neste sentido, o processo de expansão que se opera e a configuração espacial resultante da mancha urbana assumem características locais, com 
especificidades próprias, e que tornam o seu entendimento uma tarefa mais complexa. Entretanto, tomamos como premissa que os problemas enfrentados pelas cidades têm solução, que existem alternativas para o desenvolvimento e a qualidade de vida, que é possível direcionar o crescimento urbano e que os instrumentos de investigação e dispositivos para controlar tendências não-desejadas existem.

Em função das várias interpretações que os termos crescimento urbano, monitoramento territorial e estrutura espacial suscitam, consideramos fundamental expressar o nosso entendimento. Inicialmente, é importante frisar que entendemos a expansão física da cidade como um dos componentes básicos da urbanização, como um espaço social e humano. Temos levado em consideração, também, que o modelo rodoviário urbano é um dos principais fatores básicos do crescimento dispersivo e da pulverização da cidade. Assim sendo, adotamos sistematicamente o crescimento da cidade na dimensão horizontal do seu espaço como um processo que é percebido espacialmente, dinâmico, que tem extensão territorial e que resulta em configurações. Utilizamos também, sobretudo na documentação cartográfica, as expressões superfície urbana e mancha urbana para traduzir a área urbanizada no território. Uma mancha é entendida como uma porção delimitada do território que difere do ambiente que a circunda(ANJOS, 2008). Tomamos como premissa que o monitoramento espacial permite rever a história de determinados fatos geográficos, possibilitando a reinterpretação de processos ocorridos, fornecendo elementos para percepção do que acontece na atualidade, assim como propicia a verificação das suas tendências espaciais. A monitoração espacial permite caracterizar as duas dimensões essenciais da informação geográfica, ou seja, o lugar onde ela se localiza e o momento em que se realiza.Sendo os mapas uma representação gráfica seletiva do mundo real com mensagens cartográficas qualitativas e/ou quantitativas, os registros das variações no tempo e no espaço de determinadas entidades continuam sendo um dos segmentos de maior relevância e atraentes nas discussões de Cartografia Temática. 


\section{FIG. 01 \\ PROCESSO DE REGISTRO DOS VETORES DE CRESCIMENTO URBANO NO TERRITÓRIO}
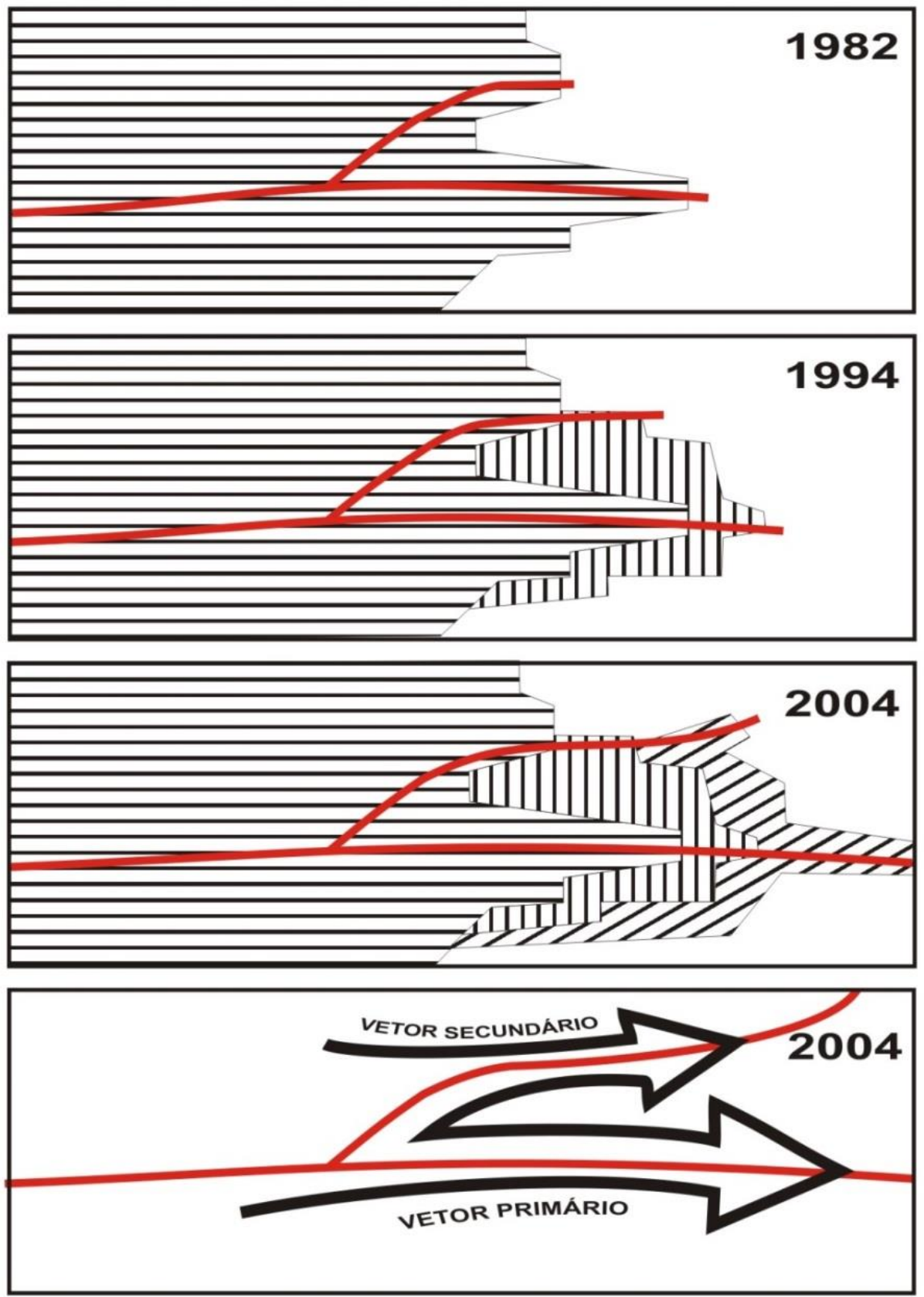

\section{LEGENDA}

ב ÁREA URBANA 1982

[II ÁREA URBANA 1982-1994
7 ÁREA URBANA 1994-2004

SISTEMA VIÁRIO ESTRURURAL

$\Rightarrow$ VETOR DE EXPANSÃO URBANA 


\section{ESTRUTURA DO MONITORAMENTO DO CRESCIMENTO URBANO DO DISTRITO FEDERAL DO BRASIL - 1964 - 1977 - 1990 - 2000 - 2014}
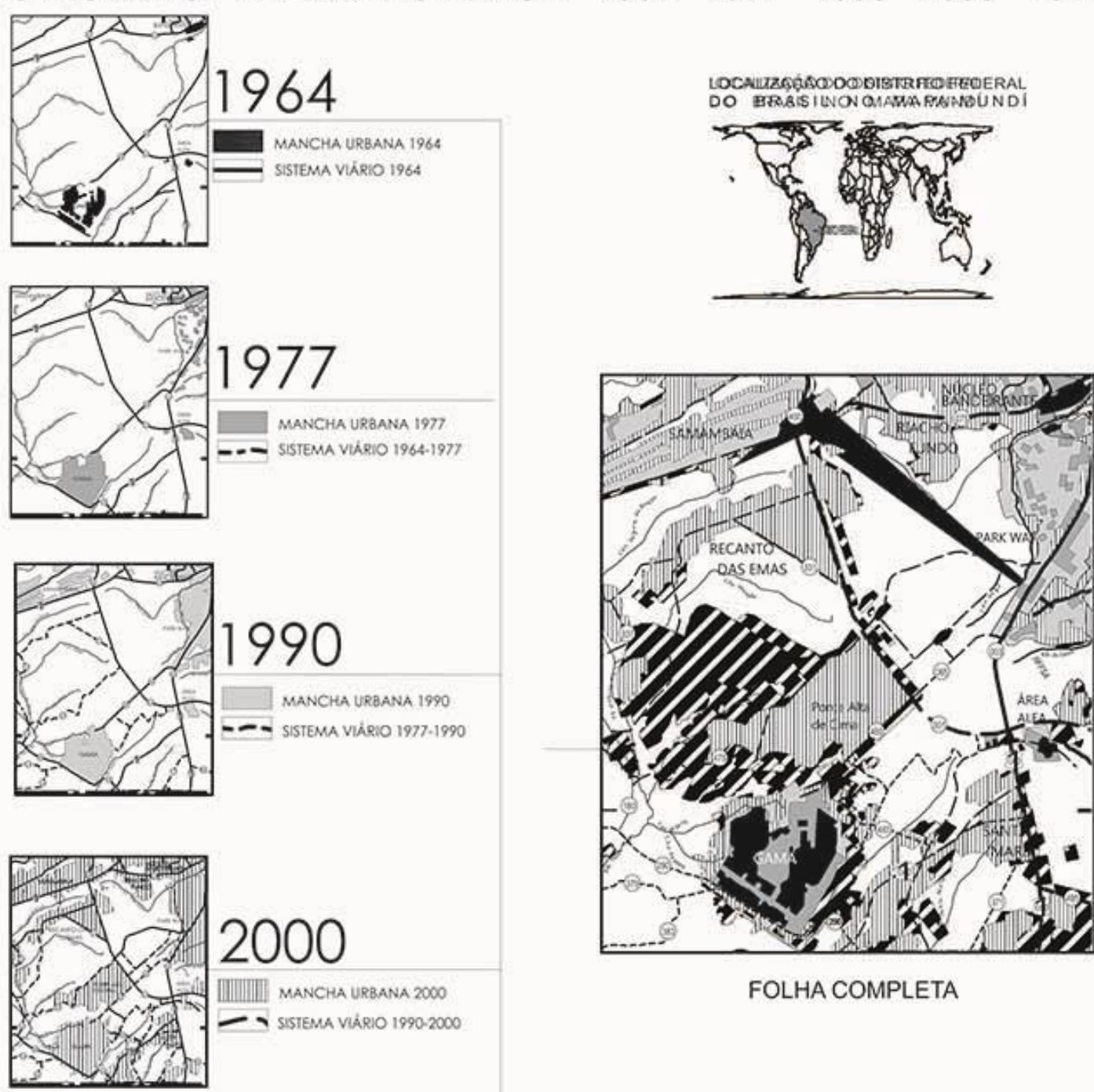

FOLHA COMPLETA

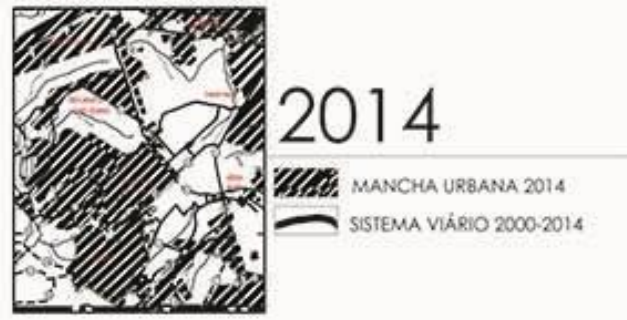

ARTICULAÇĀO DAS FOLHAS NO DF

\begin{tabular}{|c|c|c|c|c|c|}
\hline 1 & 2 & 3 & 4 & 5 & 6 \\
\hline 7 & 8 & 9 & 10 & 11 & 12 \\
\hline 13 & 14 & 15 & 16 & 17 & 18 \\
\hline
\end{tabular}

FIG. 02 
FIG. 02

FORMACAO DA BASE INFORMACIONAL DO MONITORAMENTO DA EXPANSÃO URBANA NO TERRITORIO - O EXEMPLO DA LOCALIDADE DO GAMA - DISTRITO FEDERAL 1964-2007
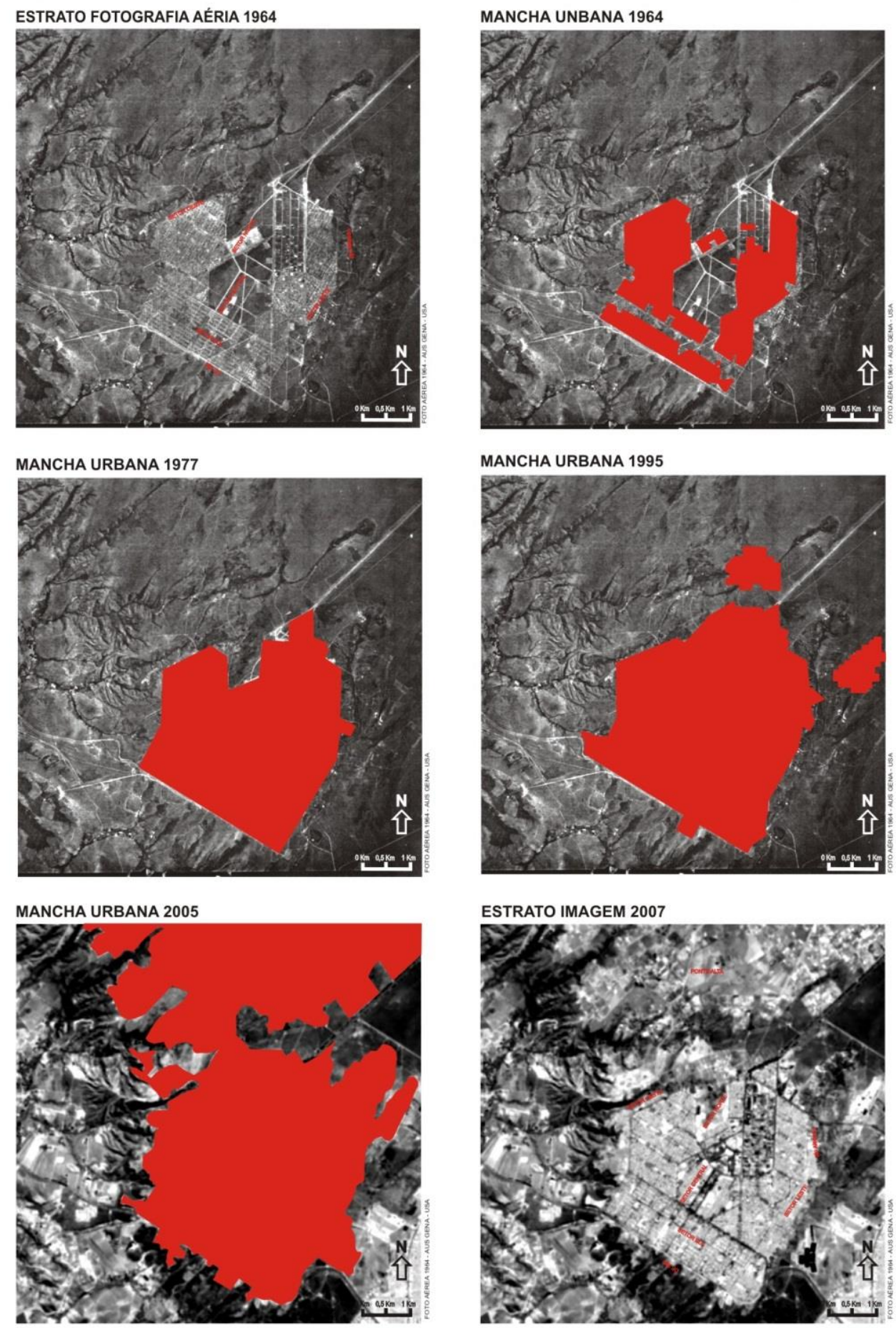

FIG. 03 
A complexidade conceitual presente nesse segmento da ciência cartográfica, em função das suas múltiplas abordagens, tem nas representações dinâmicas uma das suas preocupações fundamentais. Isso porque os entes espaciais com seus respectivos atributos mudam de posição, assim como ocorrem também mudanças das suas fisionomias no território, e estas são questões de representação gráfica ainda em discussão e em aperfeiçoamento.

As soluções mais usuais adotadas para os mapas dinâmicos podem ser caracterizadas a partir de dois princípios básicos: primeiro, tratando a informação espacial num contexto evolutivo (séries temporais ou intervalos de tempo, por exemplo), constituído por um processo que resulta em vários mapas temáticos mostrando as mudanças operantes nas suas aparências; a outra maneira para resolver as representações cartográficas dinâmicas é ser apresentado em um único mapa as mudanças operadas (posição e físionomia) em uma entidade espacial classificada. Adotamos o primeiro procedimento, dentre as soluções mais utilizadas, para mapas com representações dinâmicas. O desenvolvimento de um monitoramento territorial é uma das principais abordagens para as representações dinâmicas, isto porque, a historicidade espacial possibilita uma leitura eficaz dos movimentos ocorridos e as suas direções (ANJOS, 1991).

Ao tratarmos da sistematização do processo de evolução do espaço urbano como uma possibilidade de representar simplificadamente aspectos da dinâmica no território, estamos admitindo a existência de uma situação urbana possível de ser tratada neste processo de captura da realidade. O processo de monitoramento do crescimento urbano do Distrito Federal (DF), nosso espaço de interpretação e representação, são apresentados na sequência com alguns outros produtos espaciais derivados do processo de trabalho, tais como áreas restritivas para urbanização, espaços impermeabilizados e vetores de expansão urbana. 


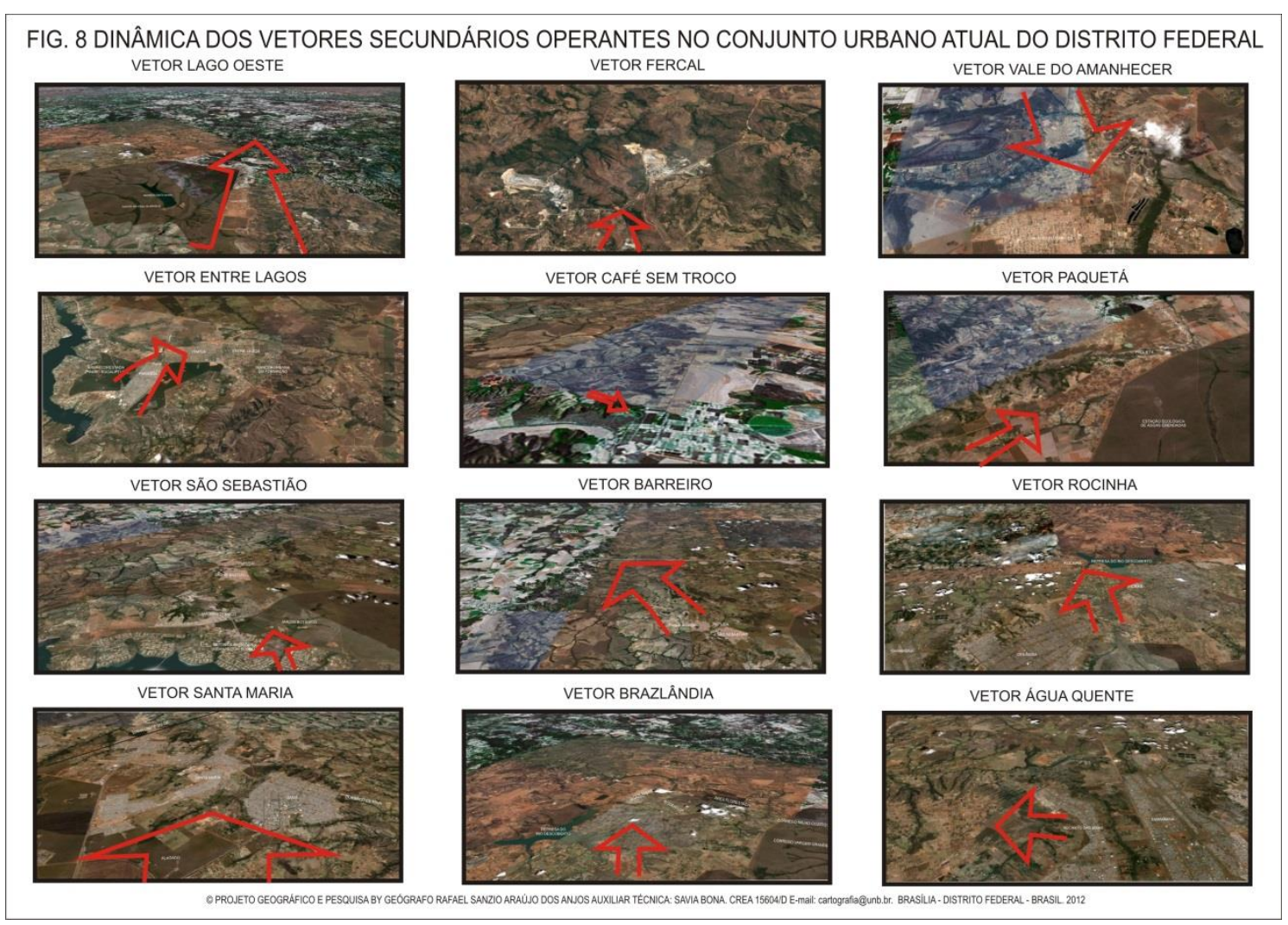

FIG. 04

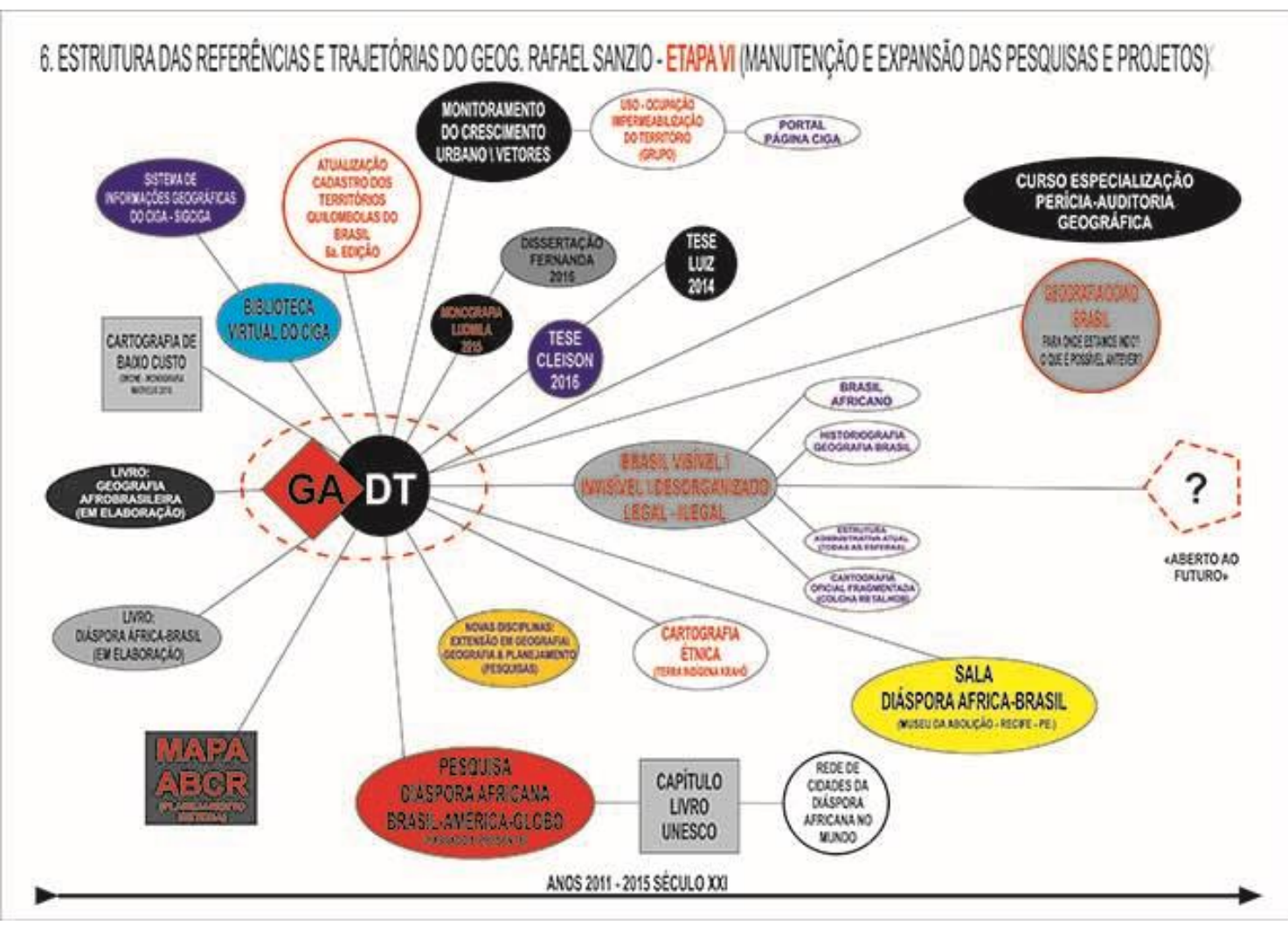

\section{Diagrama 06}




\section{FIG. 06}

DIRECOES DOMINANTES NOS VETORES DE EXPANSÃO URBANA DO DF. 2005 - 2010

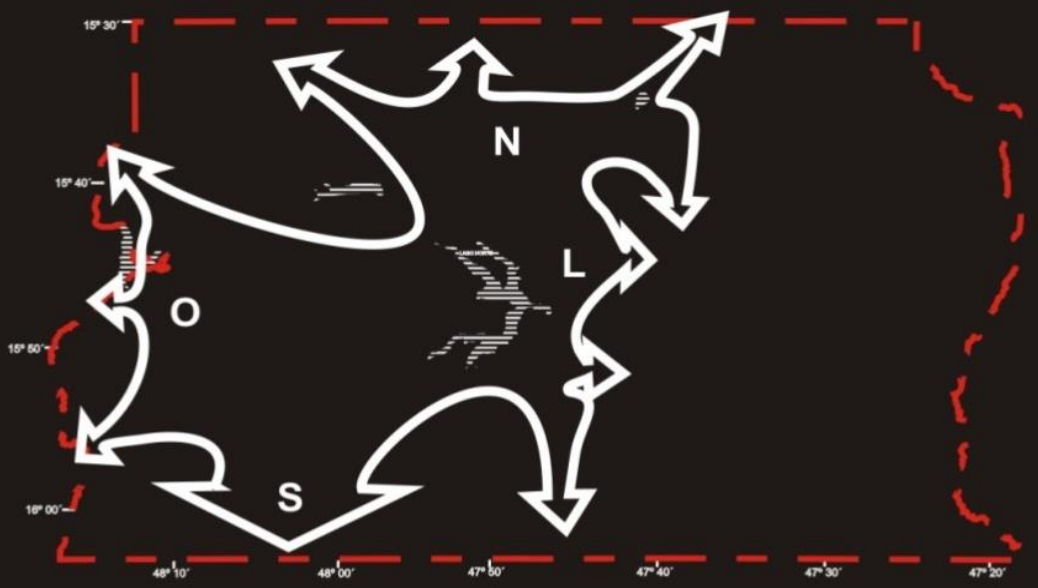

MANCHA URBANA DO DF 2010 - ESPAÇO METROPOLITANO E AAMPLIAÇÃO DOS PROBLEMAS AMBIENTAIS

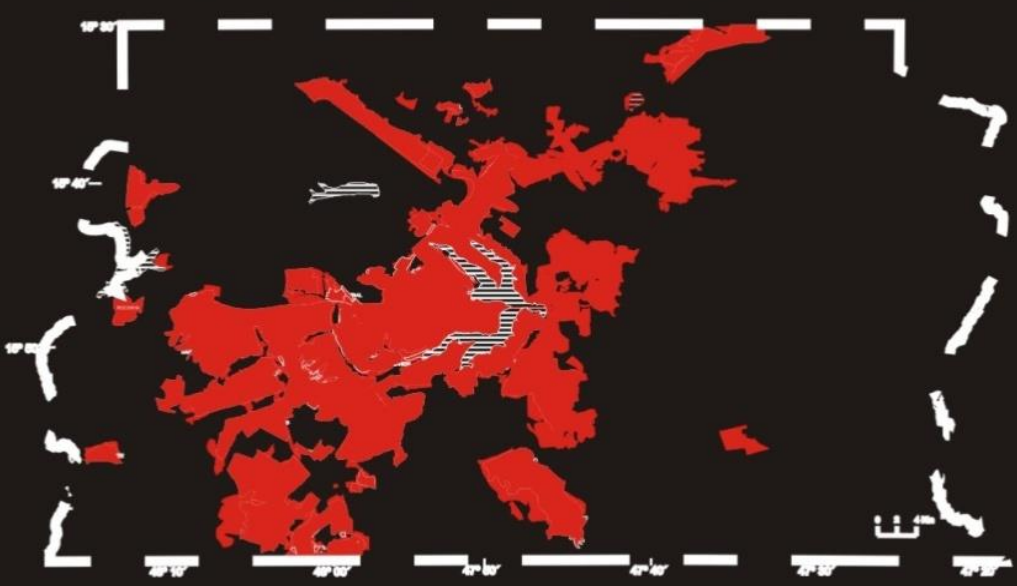

ESPACOS FISICOS RESTRITIVOS PARA URBANIZACAO E OS VETORES DE EXPANSÄO URBANA DO DF. 2005 - 2010

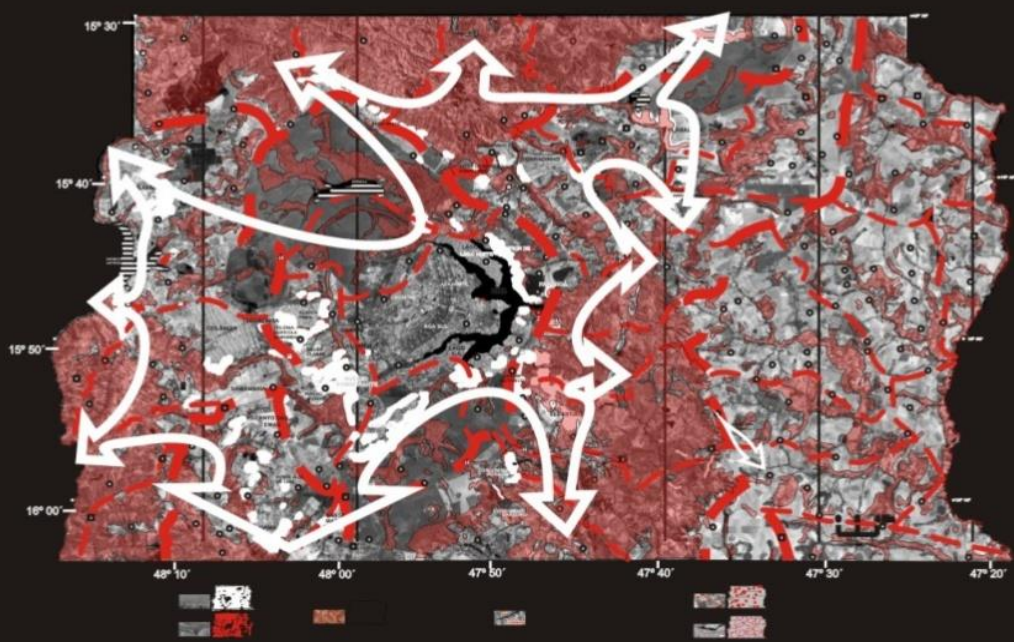

PROJETO CARTOGRÁFICO E GEOGRÁFICO BY RAFAEL SANZIO ARAÚJO DOS ANJOS - CREA 15604/D. CIGA - UnB .BRASILIA - DISTRITO FEDERAL - BRASIL, 200 .E-maitartografia @Unb.br FONTE: ANJOS, R.S.A, 1991 - ANJOS, R.S.A 1995 - ATUALIZAÇĀO DA MANCHA URBANA 2007 - ANJOS, R.S.A, 200 !

FIG. 05 
Constata-se uma tendência à estabilização do crescimento urbano horizontal do DF, seja nos registros espaciais, como nos dados quantitativos. Podemos dizer em outras palavras, que a velocidade da expansão do conjunto urbano de Brasília deve continuar num ritmo mais lento que os verificados anteriormente. Com esta perspectiva se configura uma nova territorialidade para o Distrito Federal urbano, onde se fará necessário a criação de uma estrutura ampla de planejamento e gestão, que não implique no enfraquecimento do papel do setor decisório, mas lhe atribua feições diferentes, como uma atuação mais descentralizada, mais representativa e mais atuante. $\mathrm{O}$ entendimento holístico para a criação das alternativas de ocupação territorial, que reoriente as tendências atuais não desejadas a fim de não comprometer mais desenvolvimento e a qualidade de vida da população, passa, nesse momento, por uma retomada das reflexões sobre os novos elementos espaciais atuantes na trama urbana desse território, partindo de pressupostos realistas, tanto do ponto de vista do processo de produção do conjunto urbano, com suas especificidades, quanto dos seus próprios limites.A falta de um permanente processo de avaliação pelo setor decisório sobre o crescimento do conjunto urbano de Brasília é uma lacuna histórica a ser corrigida para uma gestão com melhor apreensão da dinâmica espacial. Neste sentido, o fluxo de informação entre as Estatais, tendo um centro de planejamento territorial com a identificação mais nítida das suas competências e cumprindo o papel de gerenciador dos fluxos de dados, é uma lacuna institucional estruturalno espaço do DF e da RIDE. 


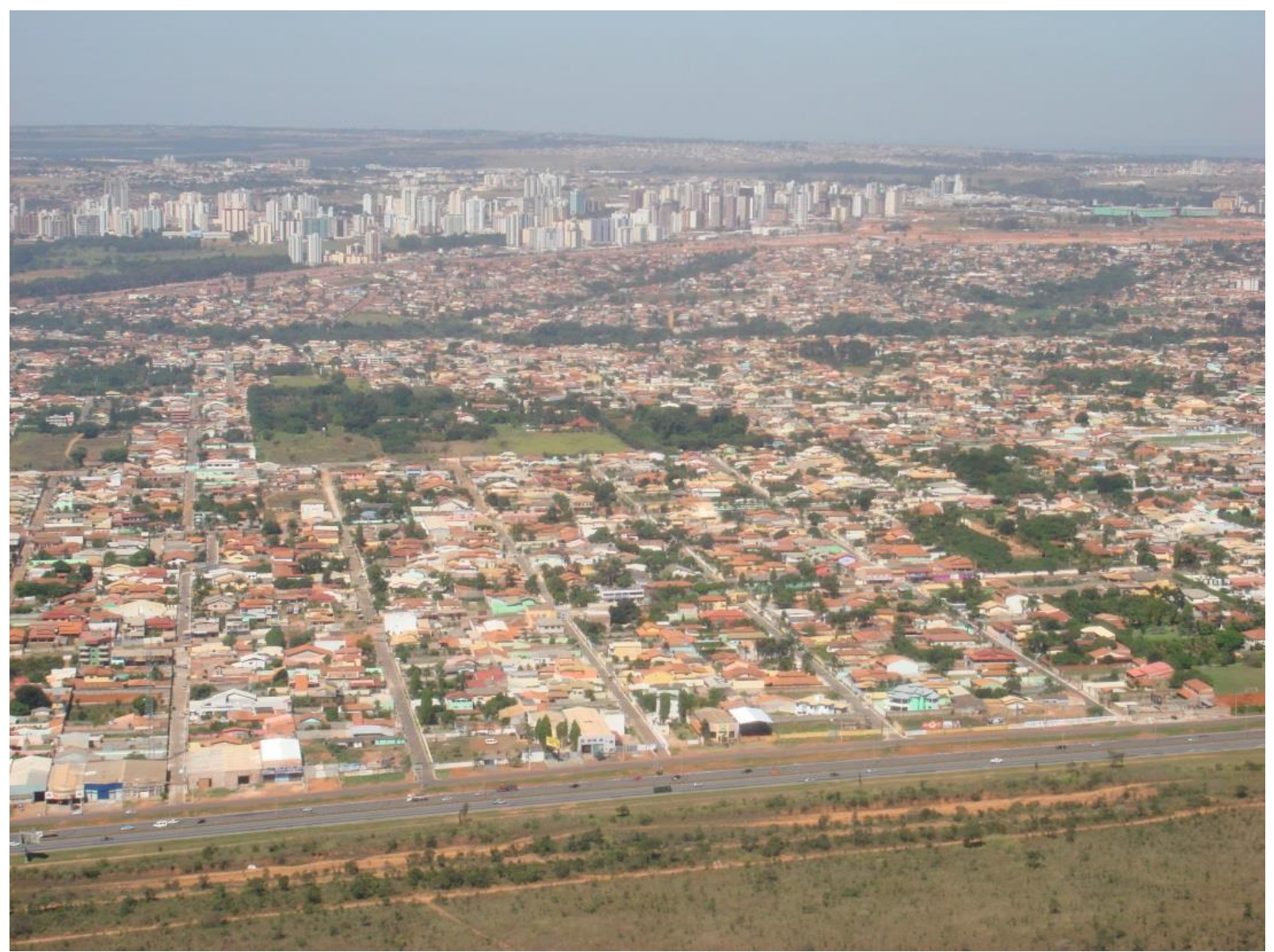

Foto 18: Vista panorâmica da região de Taguatinga, Águas Claras e Vicente Pires revelando a diversidade de tipologia e densidade espacial. Guilgermino Rocha, 2012

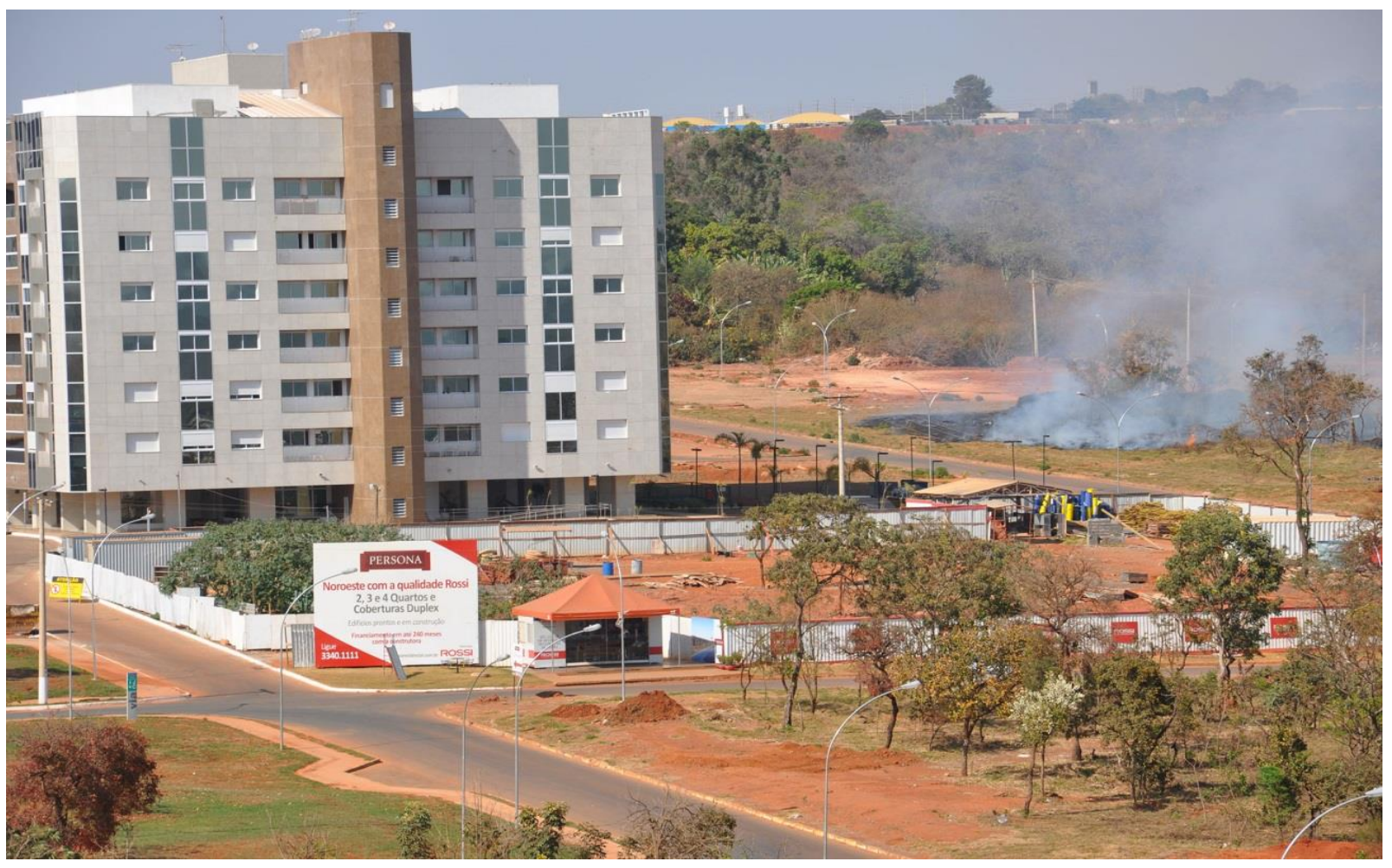

Foto 19

Revista Eletrônica: Tempo - Técnica - Território, V.7, N.1 (2016), 1:76 ISSN: 2177-4366 


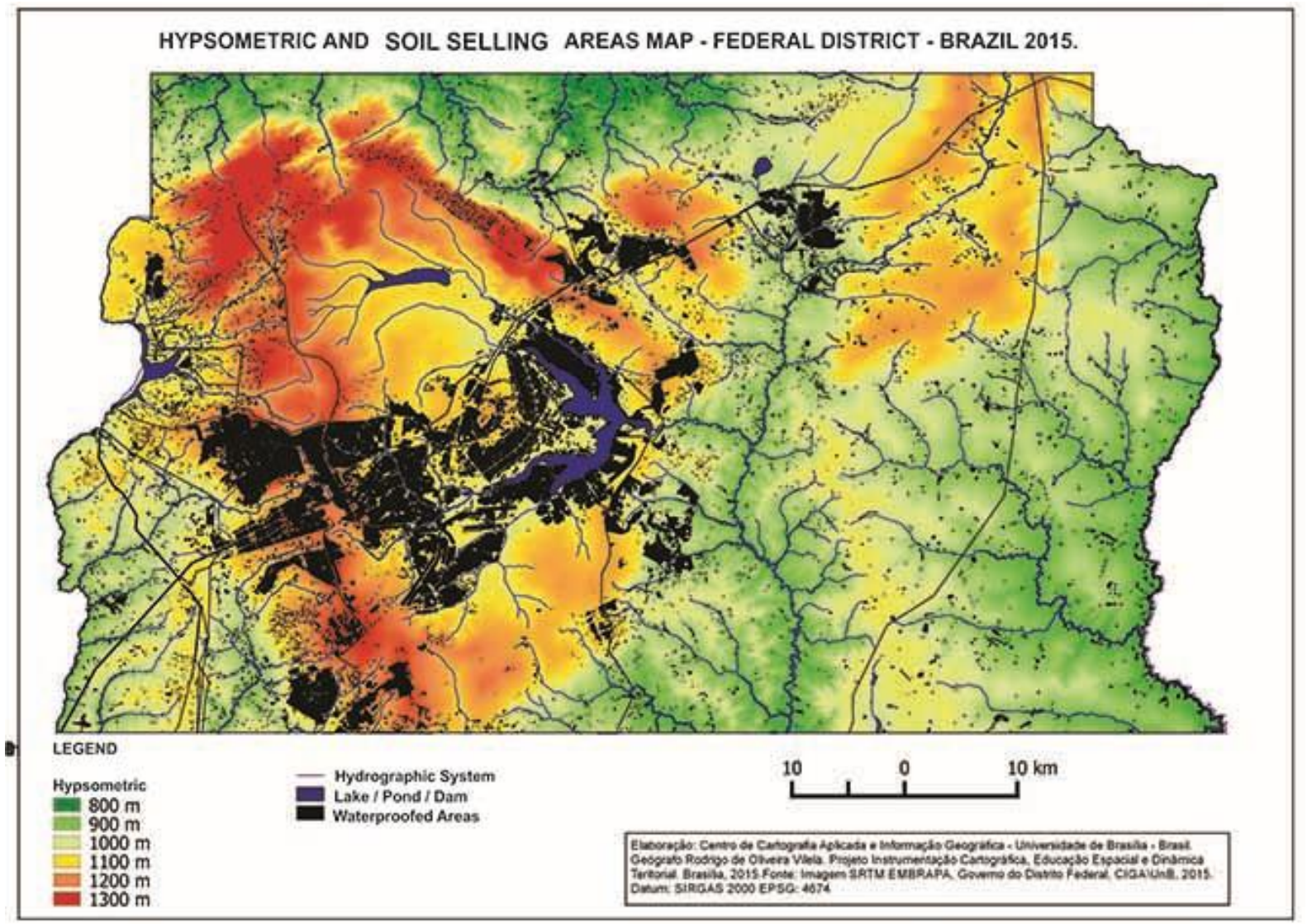

Hydrographic Basins and Soil selling areas in the Federal District - 2014.

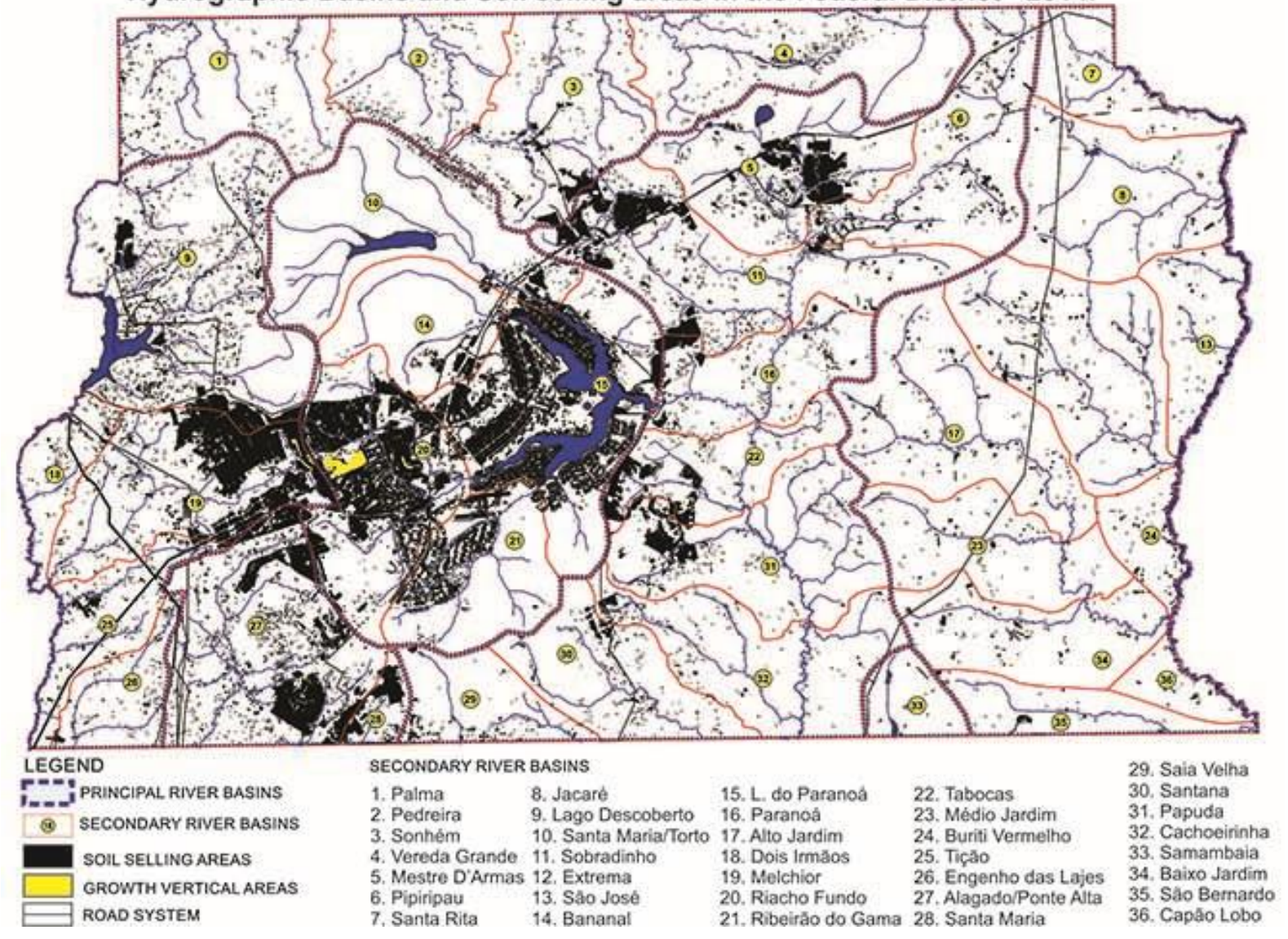

Mapa 10 e 11

Revista Eletrônica: Tempo - Técnica - Território, V.7, N.1 (2016), 1:76 ISSN: 2177-4366 


\section{ALGUMAS REFERÊNCIAS BIBLIOGRÁFICAS}

ANJOS, R. S. A. Crescimento Urbano Horizontal do Distrito Federal. Revista Humanidades, Brasília, v. 8, n. 3. Editora Universidade de Brasília, p. 407-415, 1992.

Estruturas básicas da dinâmica territorial no DF. In.: PAVIANI, A ; GOUVÊA, L.A. Brasília: controvérsias ambientais. Brasília: Editora Universidade de Brasília, 2003, p. 199-215.

Expansão urbana no Distrito Federal e Entorno Imediato (19641990): Monitoramento por meio de dados de sensoriamento remoto. Brasília, 1991. 136 f. Dissertação (Mestrado em Arquitetura e Urbanismo)- Instituto de Arquitetura e Urbanismo, Universidade de Brasília.

Modelagem dos processos formadores da dinâmica espacial urbana no Distrito Federal do Brasil, São Paulo, 1995. 220 f. Tese (Doutorado em Informações Espaciais) - Escola Politécnica, Universidade de São Paulo.

Projeto Geografia do Distrito Federal: cartografia para o planejamento do território e educação espacial. Brasília: Mapas Editora\& Consultoria, 2005.

Vetores de crescimento urbano do Distrito Federal: suas tendências atuais e os fatores espaciais intervenientes. In.: WORKSHOP. Processos formadores $e$ o espaço urbano do Distrito Federal. Universidade de Brasília/NEUR-CEAM/Depto. de Geografia-IH/Depto. de Urbanismo - IA: Brasília, 1992. 16p. (Mimeografado).

Dinâmica territorial: monitoramento - cartografia - modelagem. Brasília: Mapas Editora\& Consultoria, 2008.

BRITO, P.L. \& ANJOS, R.S.A. Planejamento territorial: O Município x A Bacia hidrográfica. Revista Eletrônica TTT CIGA-GEA-UnB. V.1, N. 1. Brasília 2010

FREITAS, J.F.. \& ANJOS, R.S.A. Monitoramento orbital da expansão urbana na cidade de Anápolis - 1997-2000. Revista Eletrônica TTT CIGA-GEA-UnB. V.1, N. 1. Brasília 2010

OLIVEIRA, S.D.R.. \& ANJOS, R.S.A. A Organização de dados de favelas para o planejamento territorial: Uma Proposta metodológica. Revista Eletrônica TTT CIGAGEA-UnB. V.1, N. 1. Brasília 2010

AVENI, A. \& ANJOS, R.S.A. Introdução a retomada do uso do espaço geográfico no discurso europeu e do Brasil no planejamento estratégico do território - Uma Introdução. Revista Eletrônica TTT CIGA-GEA-UnB. V.2, N. 1. Brasília 2011

ANJOS, R.S.A. Brasília - 50 anos de dinâmica territorial urbana. Revista Eletrônica TTT CIGA-GEA-UnB. V.3, N. 1. Brasília 2012 
GULLARD, N. \& ANJOS, R.S.A. Conflitos sócio ambientais na bacia do córrego Samambaia - DF. Revista Eletrônica TTT CIGA-GEA-UnB. V.3, N. 1. Brasília 2012

Monitoramento do crescimento e vetores de expansão urbana de Brasília. In.: PAVIANI, A; BARRETO, F.; FERREIRA, I.; CIDADE, L.; JATOBÁ, S. Brasília 50 Anos: Da Capital a Metrópole. Brasília: Editora Universidade de Brasília, 2011, p.369-396.

SERRA, G. O Espaço natural e a forma urbana. São Paulo: Nobel, 1987. 211p.

ANJOS ET ALLI. Brasília - Monitoring and Trends of Urban Growth Densites and Territorial Conflicts. SSS10 Londres, 2015 


\section{O PROJETO GEOAFRO, A GEOGRAFIA DE ESTADO E A DESORGANIZAÇÃO DAS AÇÕES PARA O TERRITÓRIO BRASILEIRO}

Inicialmente lembrarnos, mais uma vez, que as demandas para compreensão das complexidades da dinâmica da nossa sociedade são grandes e existem poucas disciplinas melhores colocadas do que a Geografia e a Cartografia para auxiliar na representação e interpretação das inúmeras indagações desse momento histórico. A Geografia, sem desprezar os seus outros elementos fundamentais, podemos sintetizar como a ciência do território e este componente fundamental, a terra, o terreiro num sentido amplo, continua sendo o melhor instrumento de observação do que aconteceu, porque apresenta as marcas da historicidade espacial; do que está acontecendo, isto é, tem registrado os agentes que atuam na configuração geográfica atual e o que pode acontecer, ou seja, é possível capturar as linhas de forças da dinâmica territorial e apontar as possibilidades da estrutura do espaço no futuro próximo. O território é na sua essência um fato físico, político, social, categorizável, possível de dimensionamento, onde geralmente, o Estado está presente e estão gravadas as referências culturais e identitárias da população (ANJOS, 2009).

Tento não perder de vista que a Geografia é a área do conhecimento que tem o compromisso de tornar o mundo e suas dinâmicas compreensíveis para a sociedade, de dar explicações para as transformações territoriais e de apontar soluções para uma melhor organização do espaço. Por isso ela é uma disciplina fundamental na formação da cidadania do povo brasileiro, que apresenta uma heterogeneidade singular na sua composição étnica, socioeconômica e na distribuição espacial. Se olharmos a realidade da educação geográfica básica da população do Brasil, onde a alfabetização cartográfica deveria acontecer e fortalecer decisivamente a nossa cidadania constamos que a maioria do nosso povo não sabe ler-entender um mapa, ferramenta fundamental para a "cultura de espaço" e esta falha básica da nossa cidadania tem trazido danos seculares na apropriação eficaz das referências territoriais nas distintas escalas de percepção espacial. Num país continental de mentalidade ainda colonial onde o conceito de ter terra significa poder, a precariedade da educação geográfica- cartográfica tem sido uma estratégia geopolítica eficaz para a manutenção da "Geografia da exclusão e da ignorância espacial". 
A maneira como olhamos, representamos e situamos a África na Geografia praticada é um exemplo desta precariedade. Este é ocontinente mais importante no suporte e na manutenção da estruturação do mundo nos últimos cinco séculos, particularmente na formação do Novo Mundo, da América e no enriquecimento e fortalecimento da Europa moderna. O Brasil, por sua vez, mesmo se fazendo desconhecer, apresenta um posição particular neste contexto global por ser a unidade política contemporânea que registra na sua hitoriografia as maiores estatísticas de importação forçada de distintos contingentes populacionais africanos ao longo dos séculos XVI a XIX. Por isso, o Brasil continental, plurirracial, multicultural e com uma historicidade em processo de reconstrução e uma diversidade étnica-cultural com conflitos tem ainda o desafio de assumir decisivamente a nação multiétnica resultante destes séculos de "conivência com ruídos" com a África.

Estes são pontos estruturais que preconizam a busca de equilíbrio social e territorial e, sobretudo um tratamento ético e alteação no paradigma político. Neste sentido, não se esgotaram ainda as interpretações dos deslocamentos das suas populações nos primórdios da suas formações e os resutados destes processos no espaço geográfico, ou seja, a busca de um melhor entendimento e representação das dinâmicas da diáspora (do passado e no presente) e, uma melhor configuração das identidades territorializadas resistentes-sobreviventes, mesmo com as ações contrarias de invisibilidade pelo setor decisório.

A Geografia de Matriz Africana que tratamos nestes anos de estudo continua sendo fruto de uma inquietação de um "Brasil invisível" secularmente, ou seja, povos e territórios que existiram e se mantém sobreviventes, mas de uma maneira marginal, não oficial na sua plenitude. Esta "Geografia da exclusão" justificada é o que questionamos aqui e propomos outras leituras e representações do espaço geográfico, onde a complexidade conflitante da África exitente-resistente no Brasil seja considerada devidamente.

As estatísticas apontam o Brasil como a segunda maior nação do planeta com população de ascendência na África e, é com relação a esse povo que são computadas as estatísticas mais discriminatórias e de depreciação socioeconômica ao longo do século XX e XXI. Nos piores lugares da sociedade e do território, com algumas exceções, estão as populações afrobrasileiras. Não é possível mais esconder que temos diferenças 
sociais, econômicas, territoriais seculares e estruturais, para as quais os "remédios" ainda estão chegando e os assuntos são empurrados para um outro dia, para a próxima semana, no mês que vem, no próximo ano, que nunca chega. E os séculos estão passando!

A manutenção do quadro de desinformação da população brasileira no que se refere ao continente africano continua sendo um entrave estrutural para uma perspectiva real de democracia racial no país. Não podemos perder de vista que entre os principais obstáculos criados pelo sistema a inserção da população de matriz africana na sociedade brasileira, está a inferiorização desta no ensino e a educação geográfica-cartográfica afrobrasileira é um dos pilares que precisa de outra perspectiva no processo educacional.

Outro ponto estrutural, ainda dirigido ao setor decisório da gestão da informação geográfica oficial do país, se refere à criação das condições necessárias para a realização de um censo demográfico mais realista e que retrate melhor a diversidade étnica brasileira e consequentemente, a verificação dos estereótipos sobreviventes e resistentes. Este tema é complexo, porque significa mudar os métodos de aferiçãoe, por conseguinte, a possibilidade de registro oficial de um "Brasil Africano" até então "invisível”. 


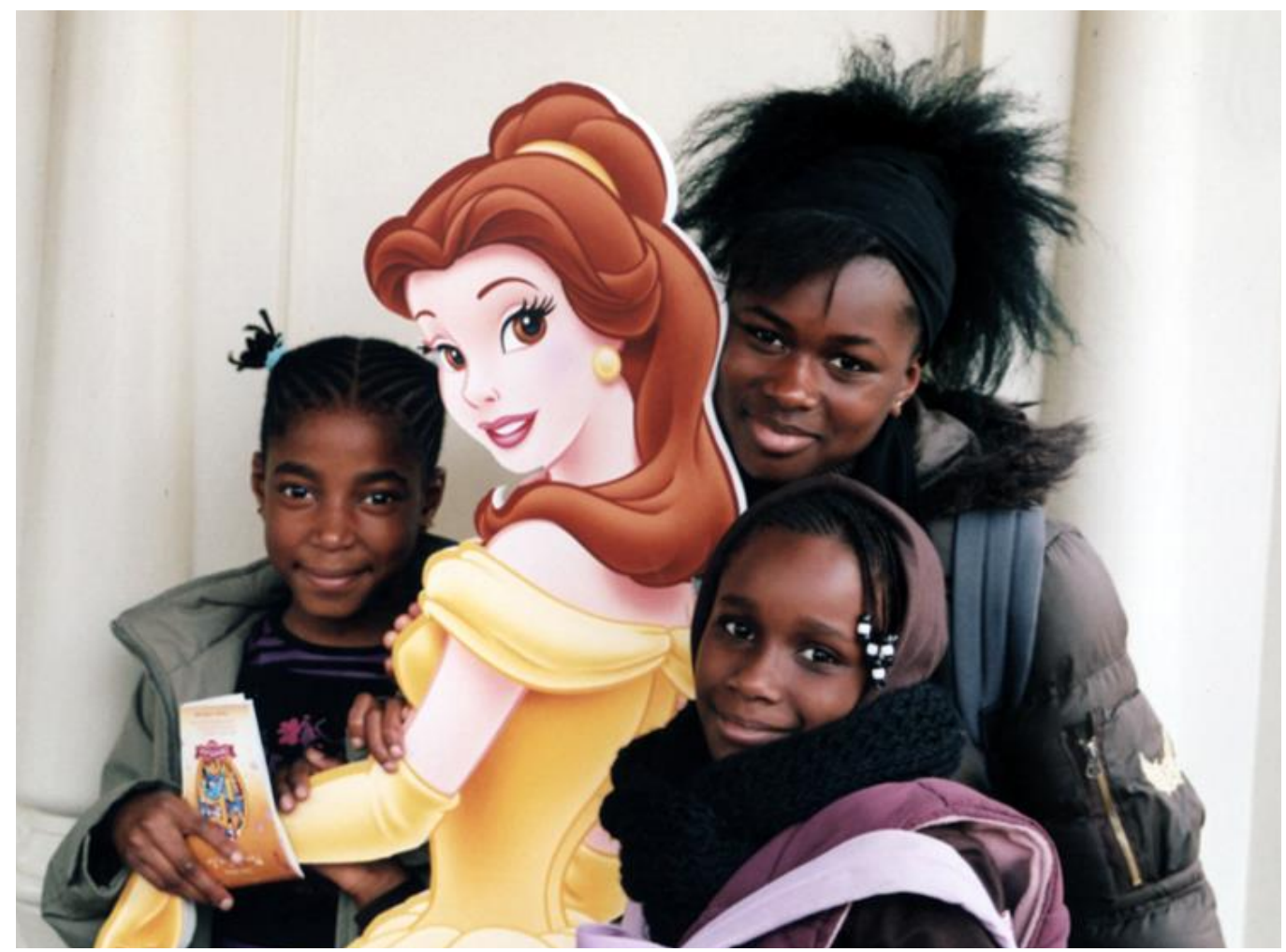

Foto 18: Meninas senegalezas na Disney World em Paris. ANJOS, R.S.A. , 2007

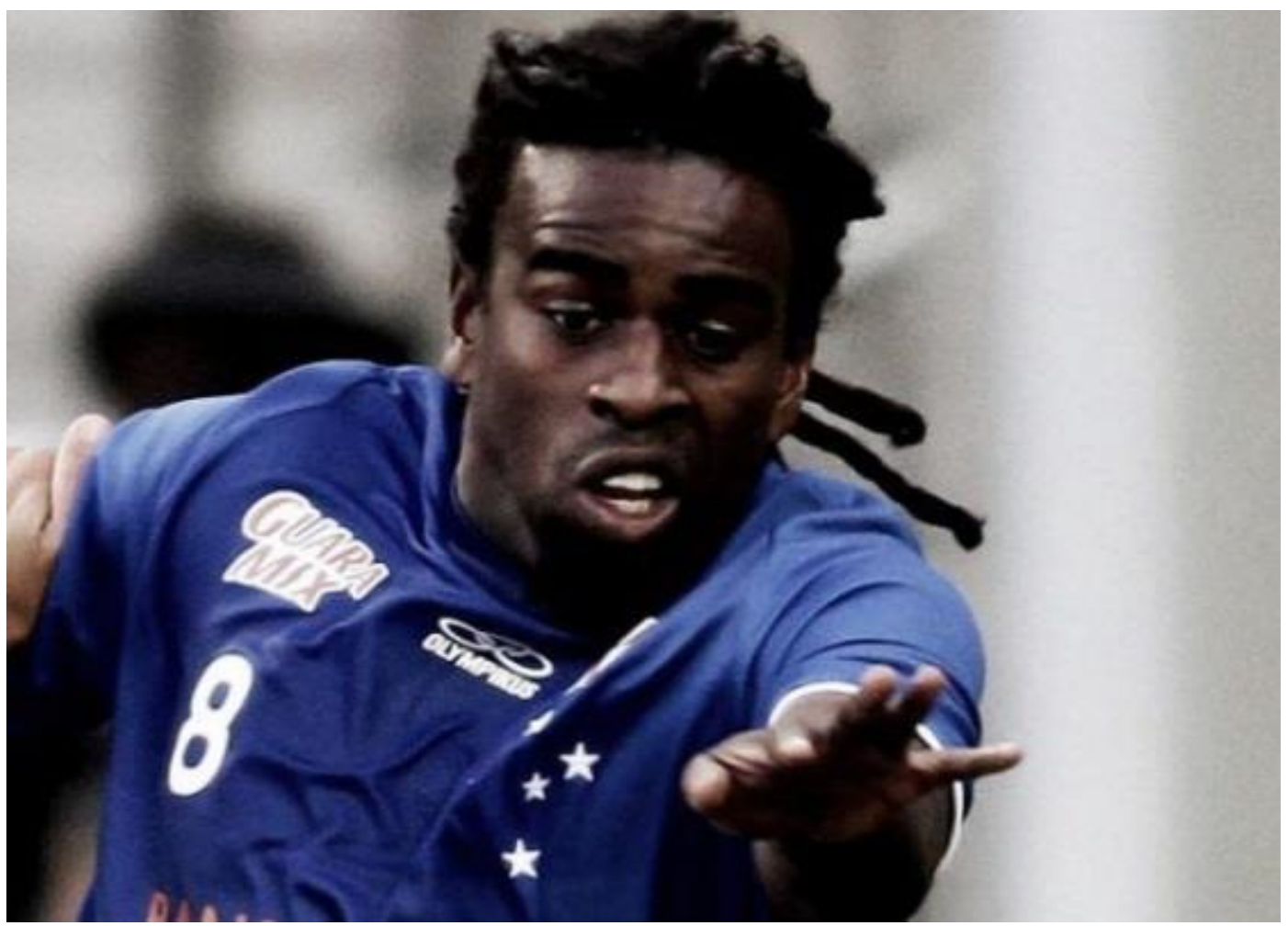

Foto 19: Matéria “Tinga, racismo e a colonialidade do poder" por Negro Belchior, 25\07\2014

Não podemos perder de vista que a questão demográfica do "Brasil africano" continua sem uma resposta e representação adequada, isto porque os critérios de 
aferição racial oficiais levam à subestimação do número real de cidadãos de matriz afrobrasileira que integram o país.

No primeiro censo realizado em 1872 a "cor da pele" definia lugares na sociedade colonial-imperial, nas quais o grupo étnico e a condição social estavam indissociavelmente ligados. Esta herança colonialista sofreu pequenos ajustes ao longo do século XX, mas se mantém da essência. O Instituto Brasileiro de Geografia e Estatística (IBGE) continua agrupado os indivíduos em brancos, pretos, amarelos e pardos, considerando brancos, pretos ou amarelos os que assim se declararem e os "outros" ficam classificados como pardos. Recentemente, esta instituição inseriu o grupo dos "índios".

O Gráfico 01 da evolução das populações preta e parda do Censo realizado em 1940 até o mais recente (2010) mostra algumas constatações relevantes: 1. A timidez do crescimento da população preta, secularmente associada a um contingente escravizado e inferior revela como o racismo e a mentalidade colonial persistem na sociedade brasileira e, 2. O crescimento espetacular dos pardos ao longo de todoas as décadas computadas. É um fenômeno! Por que será? Esta é uma importante questão que não é devidamente refletida pelo nosso povo e tem passado despercebida ao longo de algumas decadas, ou seja, a "pardarização" da população brasileira. Lembramos que associado ao "pardo" esta a indefinição da sua identidade, do seu lugar na sociedade, da sua referência ancestral, em síntese, da sua territorialidade.

Nos lembra o ditado popular: “de noite todos os gatos são pardos”. São milhares de homens, mulheres, crianças e idosos que sentem internamente que não existe, ainda, um lugar definido na estrutura social do país e o processo de "embranquecer" é uma forma de estar inserido, participando e "visto" na sociedade. Este "engano" psicológico, pelos dados oficiais, é ascendente, constatação esta que revela uma fragilidade e indefinição de identidade no Brasil contemporâneo. 


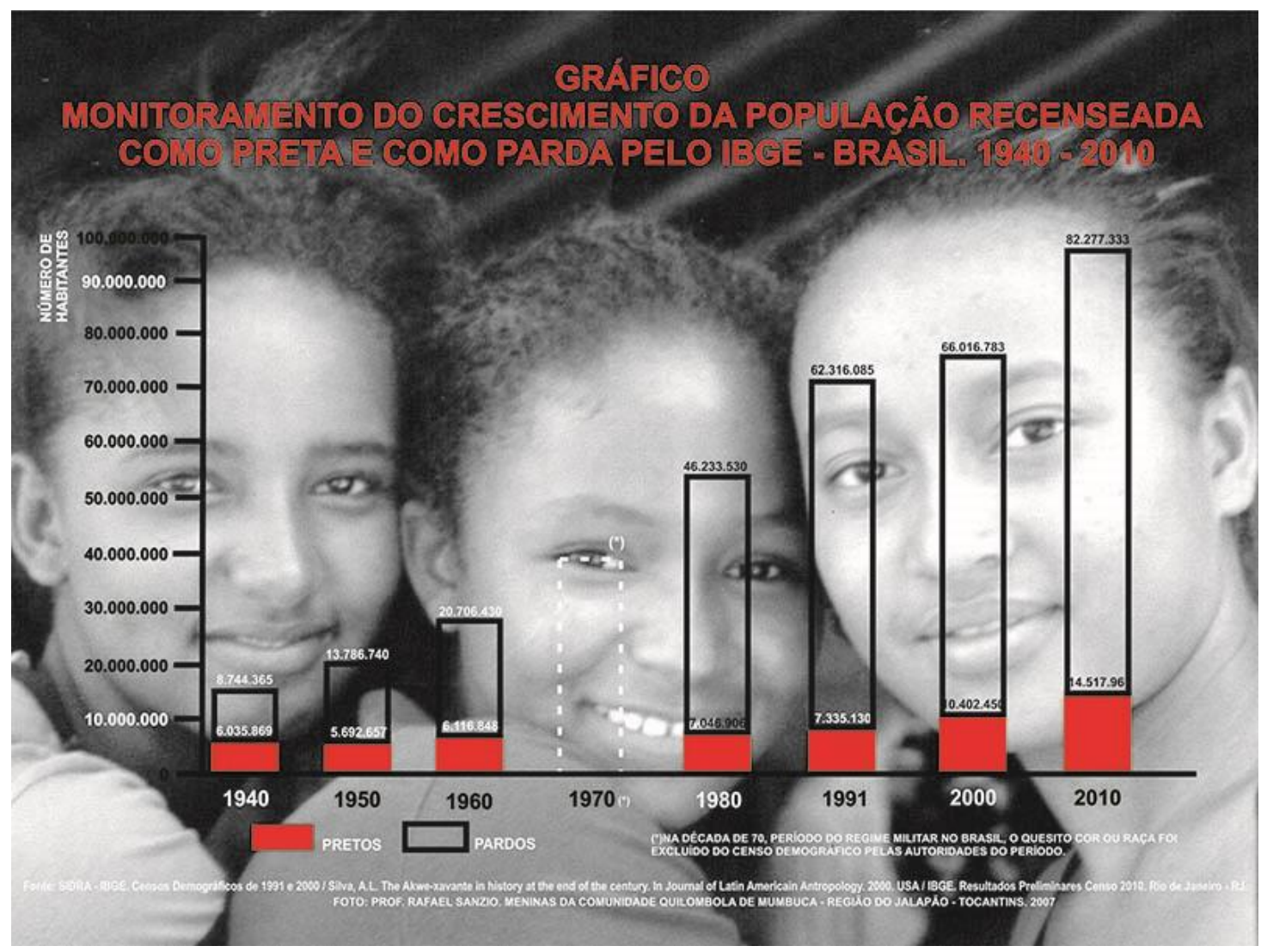

Grafico 01: Fonte: ANJOS, R.S.A. Atlas Geográfico ÁFRICABRASIL, Mapas Editora \& Consultoria, Brasília, 2014

Ainda sobre a Geografia Oficial do país, se olharmos condensadamente a história da nossa Geografia de Estado, existe uma constatação básica de que a mesma quase sempre esteve a serviço das instituições oficiais e de poder, ou seja, a sua evolução está marcada por uma série de ações de suporte ao Brasil Colônia, Império e República. Preconizamos que o espaço e a sociedade que vivemos atualmente (no sentido largo) é o resultado do que aconteceu no passado (não muito longínquo), portanto, viver sem conhecer os processos que aconteceram é estar e caminhar num "território de risco". O país se constituiu com dimensões continentais, mas a mentalidade dominante ainda é a colonial onde, por exemplo, o conceito de ter terra significa ainda poder e a precariedade da educação geográfica-cartográfica tem sido uma estratégia geopolítica eficaz para a manutenção da "Geografia da invisibilidade e da ignorância espacial”. 


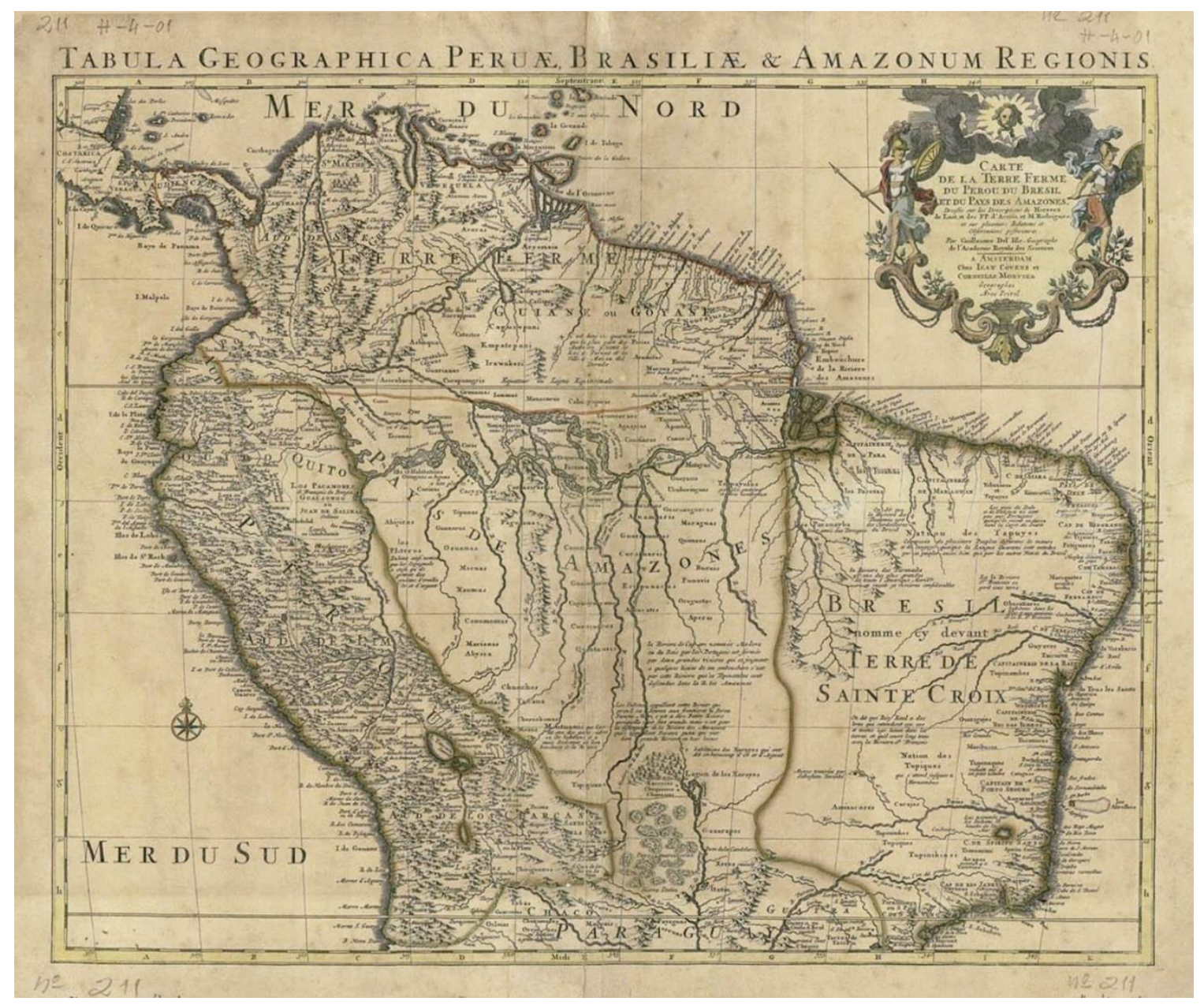

Mapa 12: Fonte: Carte de la Terre Ferm du Perou du Bresil et du Pays des Amazones. 1703. Acervo do Arquivo Nacional de Angola - Código: FZ MAP 376

A Geografia de Estado do Brasil vai se desenvolver sobre este contexto secular de dominação e exploração dos territórios e dos povos subjugados e inferiorizados (matrizes "indígenas" e africanas). O Brasil Colonial foi quem mais importou forçosamente seres humanos africanos de distintas matrizes étnicas e o último a sair do sistema escravista, resolvido institucionalmente com a assinatura da Lei Áurea (1888), devido a pressões internacionais e num contexto interno de tensão entre segmentos com interesses distintos da sociedade dominante e com desdobramentos marcantes na sociedade e no território brasileiro.Esse fato mostra por que o Brasil vai se manter com um pensamento social dominante racista até os dias atuais, ou seja, saiu do período escravocrata "sem querer", portanto com esta resistência não resolvida secularmente. A constatação nas ações do Estado e do sistema dominante é de se configura ainda um preconceito secular e uma mentalidade escravocrata dominante na sociedade classista e hierarquizada e no uso do território contemporâneo. 


\section{A ÁFRICA, A AMÉRICA, A EUROPA E O SISTEMA ESCRAVISTA}

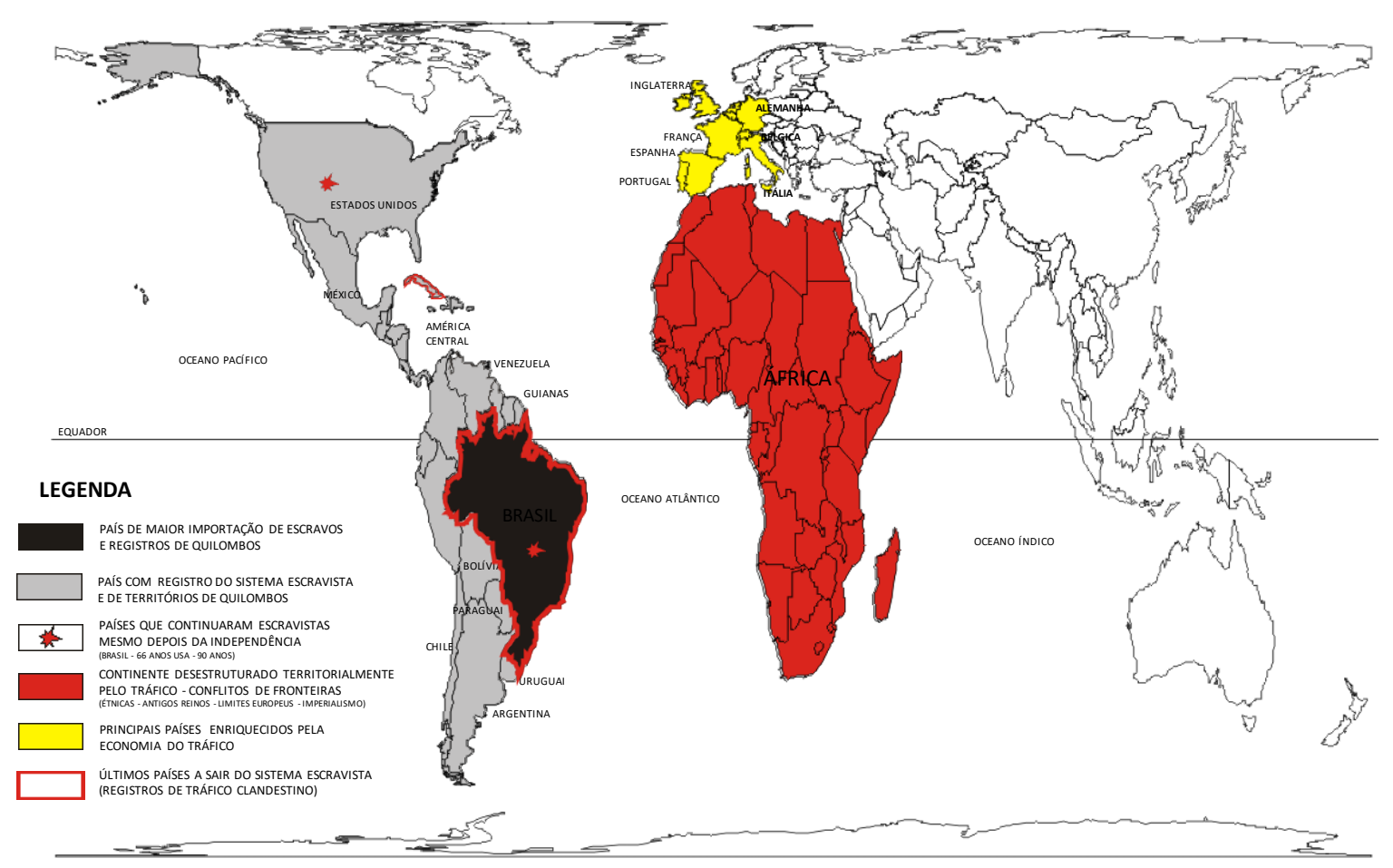

Mapa 13 Fonte: ANJOS, R.S.A. Geopolítica da Diáspora África-América-Brasil. Séculos XV-XVI-

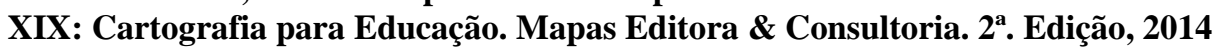

Ao observarmos as regiões de produção colonial - imperial e a distribuição demográfica atual do Brasil (Censo 2010-IBGE), a constatação espacial mais evidente é que o "espalhamento" da nossa população se processa ainda nos mesmos espaços coloniais, ou seja, os outros territórios continuam sob o controle ou a serem controlados pelos seguimentos dominantes e o setor decisório (o Estado) não consegue alterar esta Geografia Colonial ainda persistente. Esta realidade geográfica evidencia o quanto (conscientes ou inconcientes) trabalhamos para a manutenção de uma estrutura espacial conservadora cujas formas de espalhamento dos usos do território se dão de forma conflitante nas suas fronteiras e nos grupos socioeconômicos envolvidos e com lugares bem demarcados no sistema vigente, mesmo com as contradições na fragmentação do espaço. 


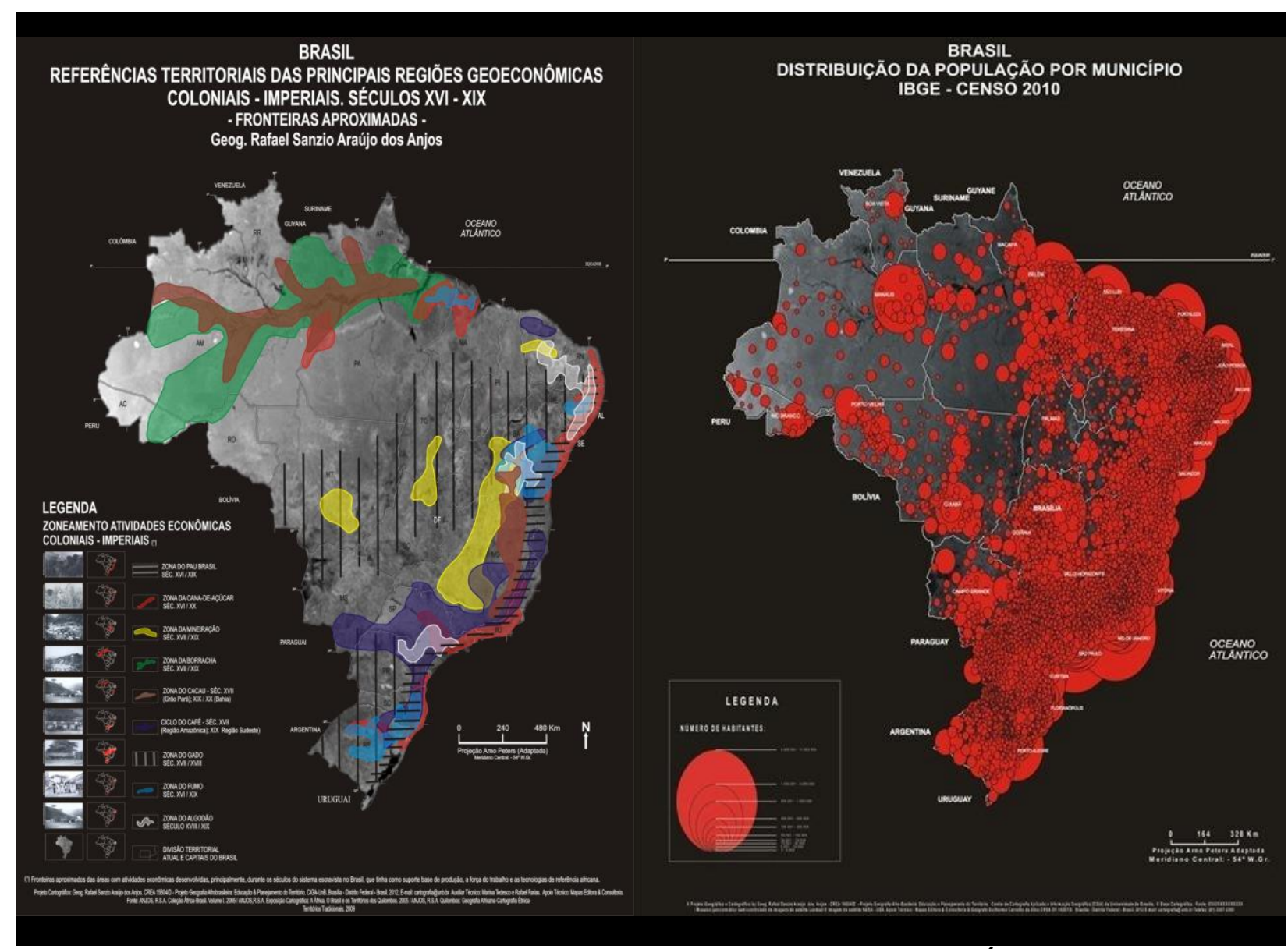

Mapas 14 e 15: Fonte: Anjos, R.S.A. Quilombos: Geografia Africana - Cartografia Étnica -

Territórios tradicionais. MapasEditora \& Consultoria, 2009 \ANJOS, R.S.A. Atlas Geográfico:

Africabrasil, Mapas Editora \& Consultoria, 2014

A forma como o Estado brasileiro contemporâneo tem conduzido a política cartográfica e geográfica no país revela uma fragmentação institucional e das ações, costituindo um modelo de governança que fortalece os conflitos operacionais e de atribuições, mas sobretudo causa um dano irreparável na gestão eficaz sobre o território nacional de proporções continentais. A figura abaixo representa graficamente este processo fragmentário na estrutura governamental. O círculo amarelo representa a forma corriqueira como são tratadas as demandas governamentais com rebatimento geográfico-cartográfico, ou seja, uma configuração de parcelamento, portanto dividido entre vários órgãos cada um com uma parcela do problema (retângulos azuis).Verificamos que esta configuração vem fortaleçendo a dispersão da gestão e a questão básica nesse processo fragmentário é quem se responsabiliza pela demanda central (círculo central em laranja com a interrogação). Se observarmos o lócus principal deste modelo governamental na esfera federal, o espaço da concentração de ministérios e do setor decisório do país, verificaremos a complexidade do fluxo de 
ações governamentais para demandas territoriais do tipo "cama de gato", ou seja, pouco foco no direcionamento da solução e a evidente dispersão no processo de gestão institucional.

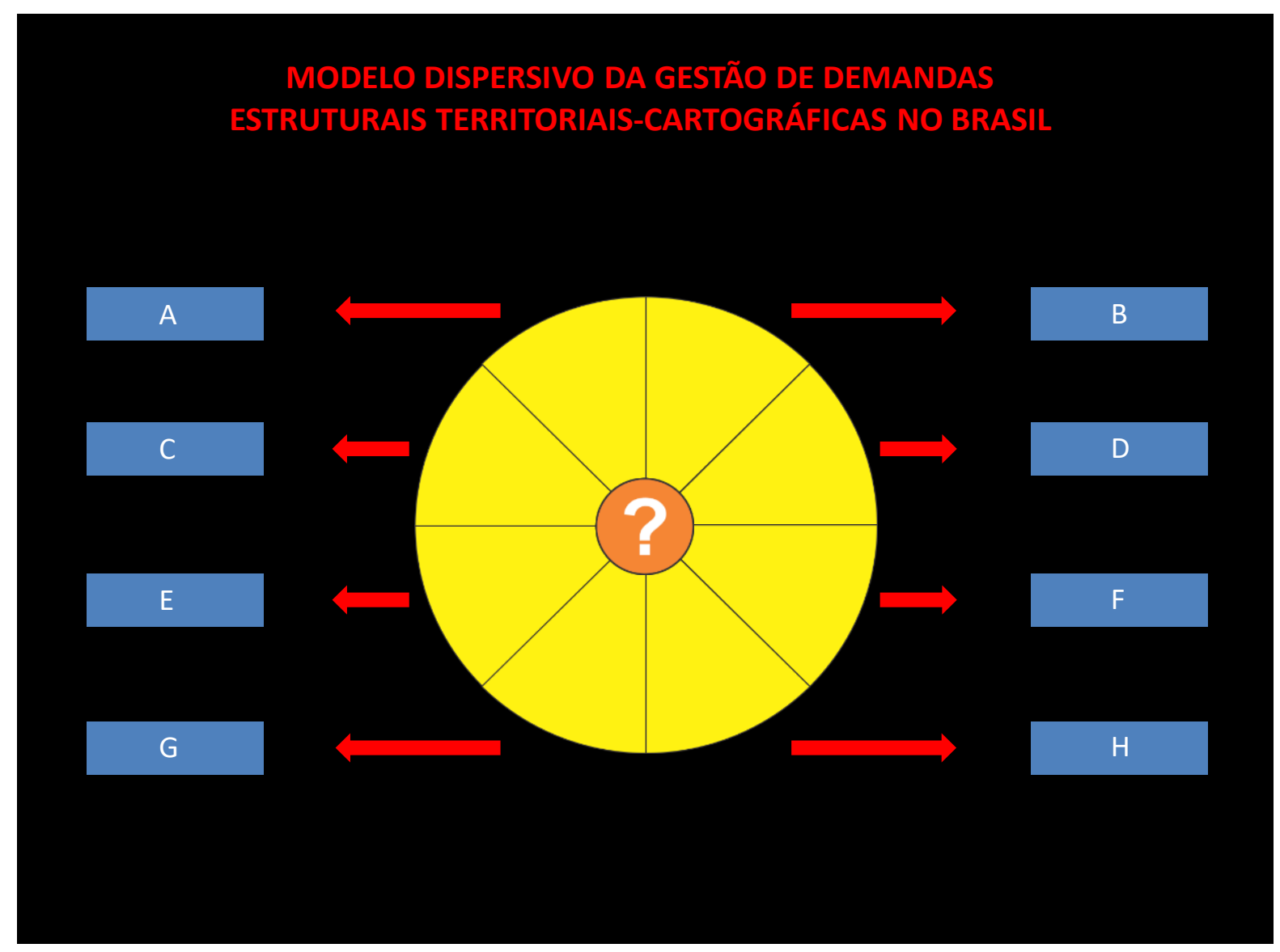

Fig. 06 Fonte: Anjos, R.S. As geografias oficial e invisível do Brasil: Algumas referências. Revista GEOUSP. V.19 N.2 (2015) 


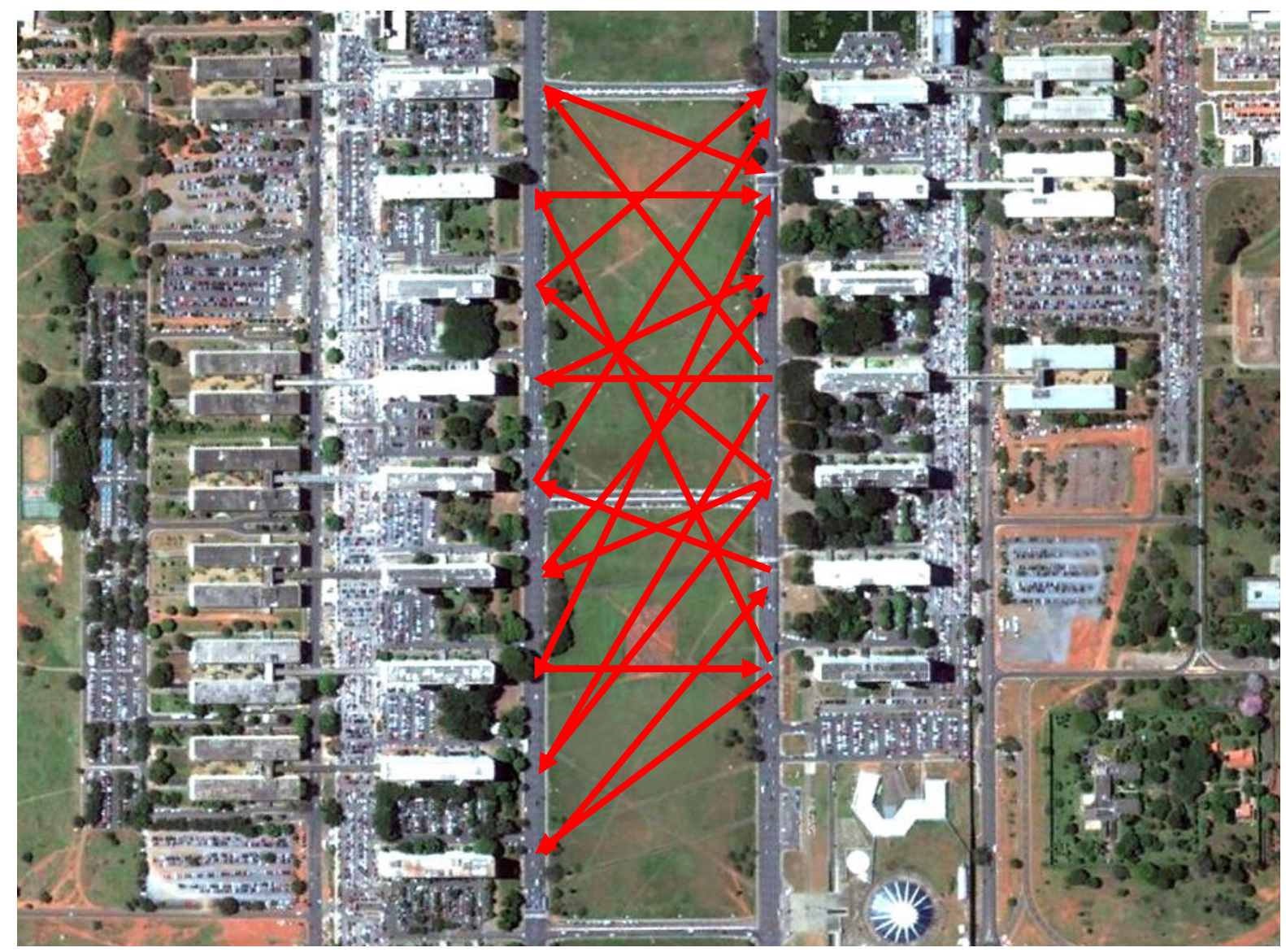

Fig. 07: Esplanada dos ministérios em brasília e o fluxo das ações institucionais tipo "cama de gato".

Fonte: ANJOS, R.S. As geografias oficial e invisível do Brasil: Algumas referências. Revista GEOUSP. V.19 N.2 (2015)

Dois exemplos com evidêcias bem explícitas desta forma de gestão governamental, são dados a seguir.

O primeiro é referente à forma como a Cartografia Oficial está sendo gerida atualmente no país continental, pulverizado entre quatro ministérios, com orçamento e prioridades de ações distintas, são eles: Ministério da Defesa, operacionalizado pelo DSG; Ministério do Planejamento, conduzido pelo IBGE; Ministério da Integração Regional, com a atuação da Codevasf (Vale do Rio São Francisco); Ceplac (sul da Bahia); Sudene (Região Nordeste) e Ministério do Desenvolvimento Agrário, com ações da Embrapa (pontualmente em São Paulo). 


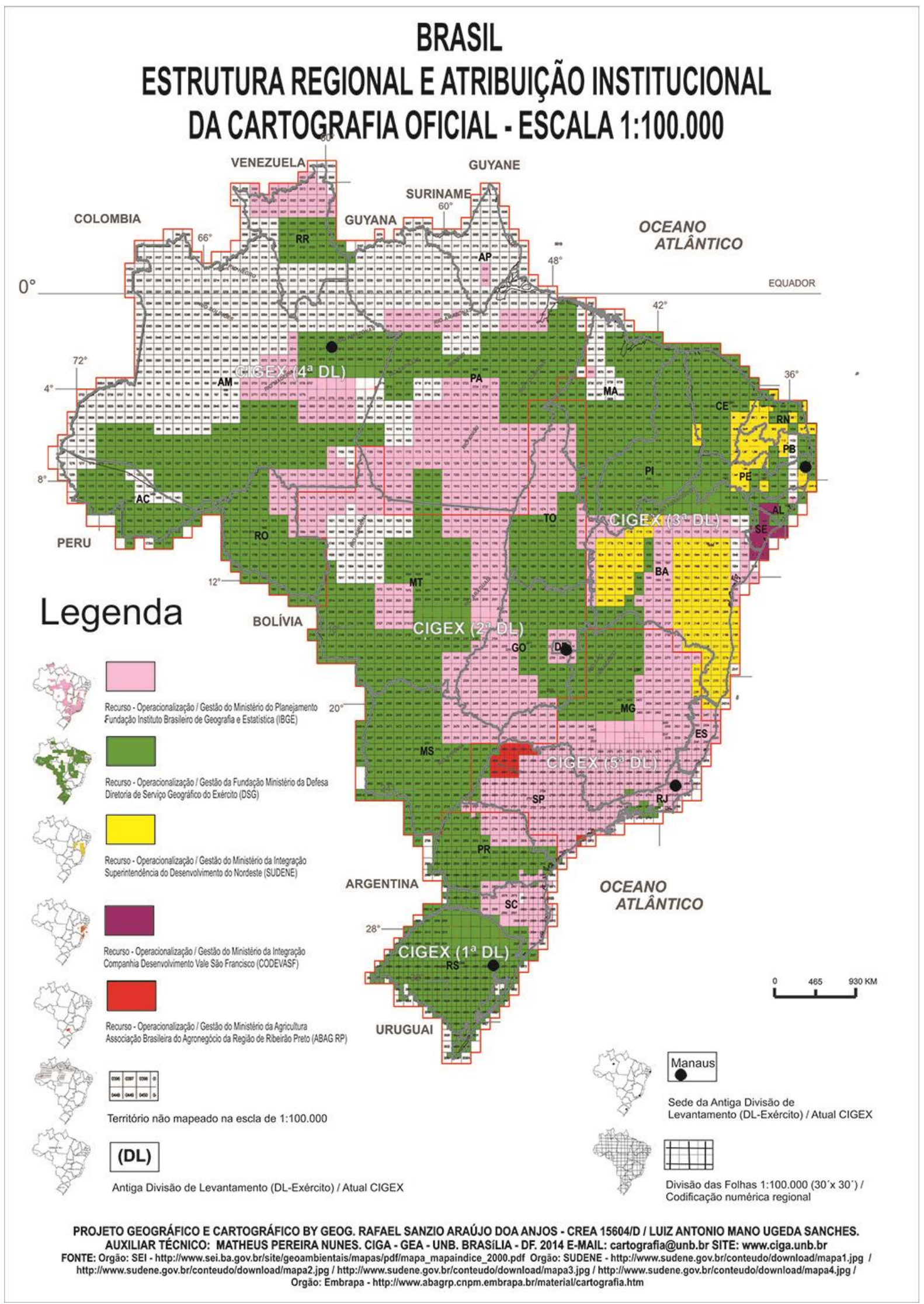

Mapa 21: Fonte: Anjos, R.S. As geografias oficial e invisível do Brasil: Algumas referências. Revista GEOUSP. V.19 N.2 (2015) 
Se observarmos o mapa índice das cartas sistemáticas 1:100.000 (escala básica do processo de planejamento onde 1 centímero no mapa corresponde a 1 quilômetro no mundo real) do Brasil, representado no mapa-índice abaixo verificamos esta "colcha de retalhos" que se configura na cartografia brasileira, fato que revela a grande quantidade de espaços ainda sem mapeamentos nesta escala básica que é fundamental para iniciar qualquer processo de conhecimento e ações sobre o território, assim como um quadro quase que generalizado de desatualização da produção cartográfica existente (a maioria dos mapeamentos foram realizados nas décadas de 1970 e 1980).

O outro exemplo da ineficácia na gestão das demandas territoriais pelo setor decisório dentro da Geografia que caracterizamos aqui como "Invisível ou não Oficial" no Brasil, destacamos o esquecimento proposital das comunidades e dos territórios descendentes de antigos quilombos, sítio geográfico estratégico onde se agrupavam, principalmente, povos de referência africana, mas, também, índios e europeus excluídos da socidade, que se rebelavam contra o sistema escravista da época, formando comunidades livres, autosustentáveis e com forte organização territorial, constitui uma das questões emergenciais e estruturais da sociedade brasileira atual.

Mesmo passados mais 127 anos da sanção da Lei Áurea pelo regime imperial, a história e o sistema oficial brasileiro ainda continua associando à população de matriz africana uma imagem de "escravizados" e aos quilombos sempre como algo do passado, como se esses não fizessem mais parte da vida contemporânea do país.

As ações do setor decisório, se mostram conflitantes e contraditórias. Apesar das disposições constitucionais (1988) e da obrigatoriedade de alguns organismos governamentais para tratarem e resolverem demandas das questões dos quilombos contemporâneos, é possível constatar, de uma forma quase que estrutural, que a situação tem apresentado um tratamento caracterizado por ações episódicas e fragmentárias (Modelo "Cama de Gato"), fato que compromete o direcionamento de uma política definida para o equacionamento dos seus problemas fundamentais, ou seja, o seu reconhecimento dentro do sistema social brasileiro e a demarcação e titulação dos territórios ocupados.

Essa problemática tem como "pano de fundo" a falta de prioridade políticos e heranças preconceituosas sobreviventes no pensamento social dominante do Brasil atual. Poderíamos complementar um pouco mais essa constatação apontando a continuidade da falta de comprometimento para a formação de uma base informacional 
unificada, assim como uma cartografia oficial e as disputas e os conflitos institucionais por espaço para a condução dessa questão, como fatores que dificultam decisivamente as resoluções do seu problema central: a posse efetiva da terra, ou seja, a definição oficial da fronteira afrobrasileira. A terra assegurada, que significa ainda na mentalidade colonialista do setor decisório poder, se configura como o principal elemento de negociação e conflito na resolução dessa pendência secular.

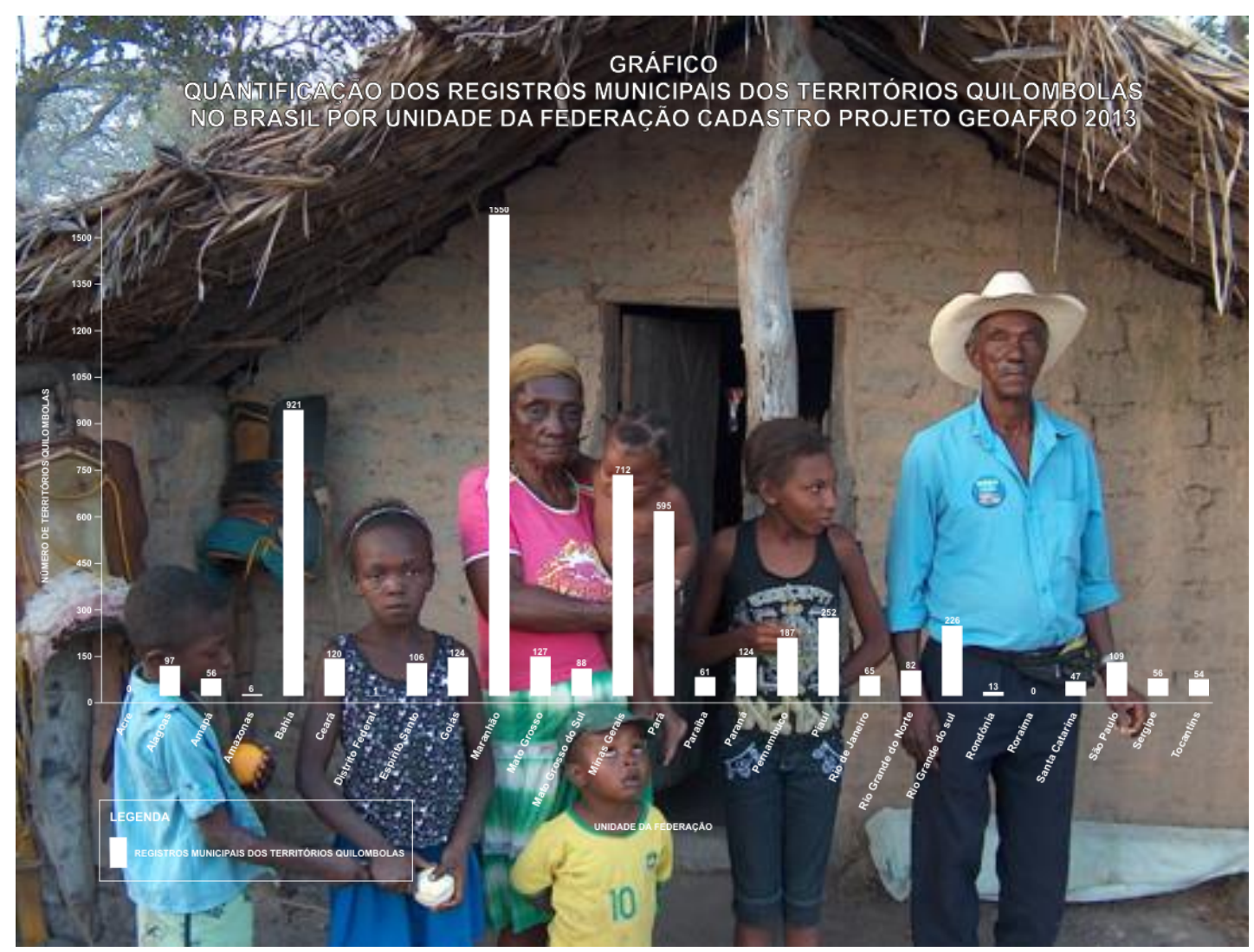

Grafico 02: Fonte: Anjos, R.S.A. Atlas Geográfico: Africabrasil, Mapas Editora \& Consultoria, $2014 \backslash$ Foto: Rodrigo Vilela e Rafael Farias, 2006 


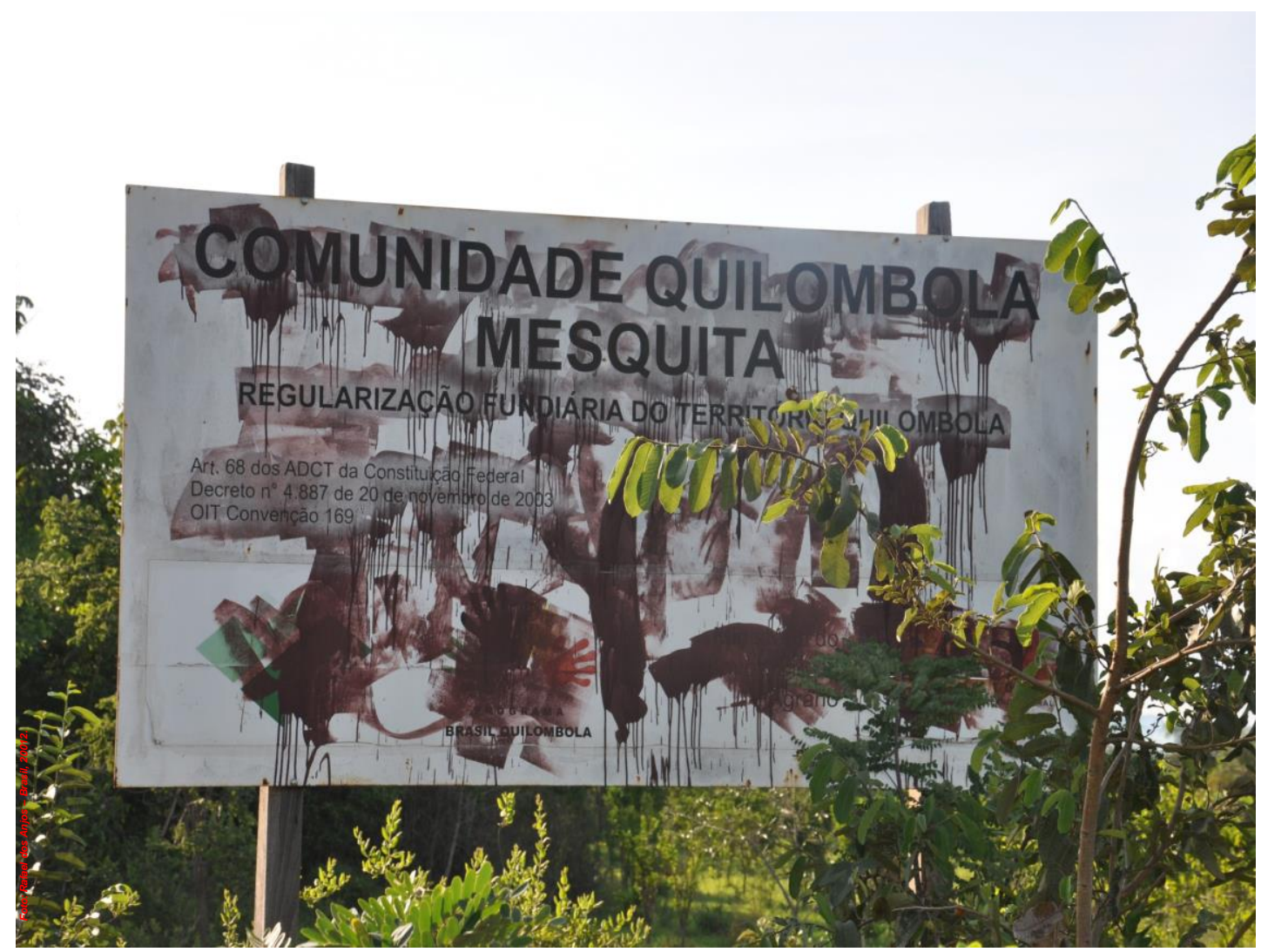

Foto 21: Anjos, R.S.A., 2009

A história da Geografia de Estado no Brasil revela um gráfico com barras bem expressivas da sua importância no período Colonial e Imperial, mas com evidente decréscimo ao longo do século XX e uma situação de adormecimento constatada nesta duas décadas do século XXI. Esta constação se revela evidenciada sobretudo na banalização dos conceitos geográficos e cartográficos no universo acadêmico (território, mapa, escala, mapeamento, espaço, cartografia, paisagem, região, dentre outras usadas aleatóriamente por várias áreas do cohecimento) e na sociedade civil (todo celular tem GPS, mapas variados, imagens de satélite multiescalar, dentre outras referências geográficas-cartográficas de fácil acesso e sem contextualização). Este período de inseguranças pode ser assumido mais devidamente pela Geografia e pela Cartografia e serem enfrentadas nas brechas e oportunidades da atualidade. As possibilidades para o futuro próximo que significaria sinalizarmos com ações para alterar a tendência do Gráfico 03 não promissor, dependerá da construção coletiva da comunidade geográficacartográfica. 


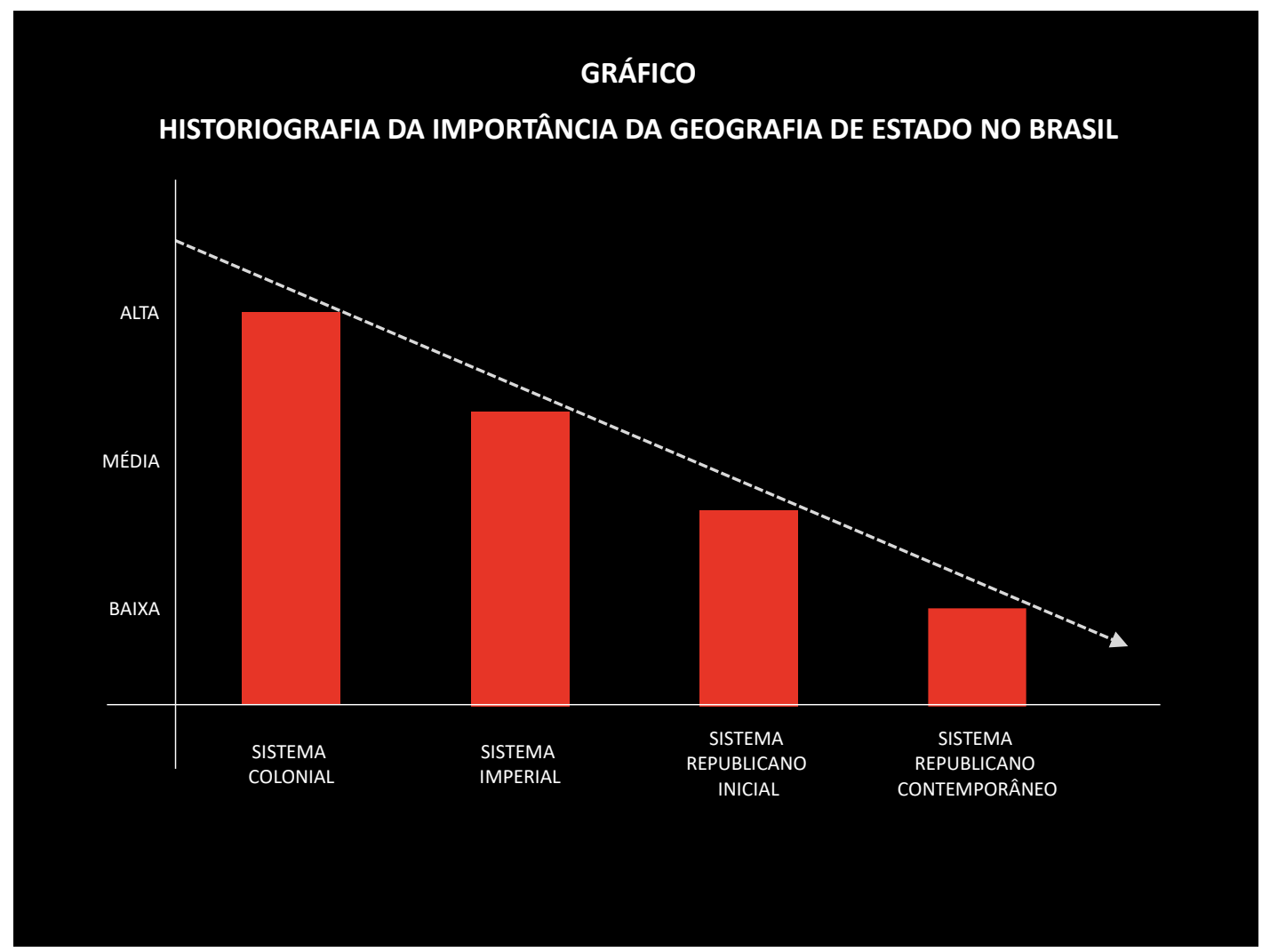

Grafico 03: Fonte: Anjos, R.S. As geografias oficial e invisível do Brasil: Algumas referências. Revista GEOUSP. V.19 N.2 (2015)

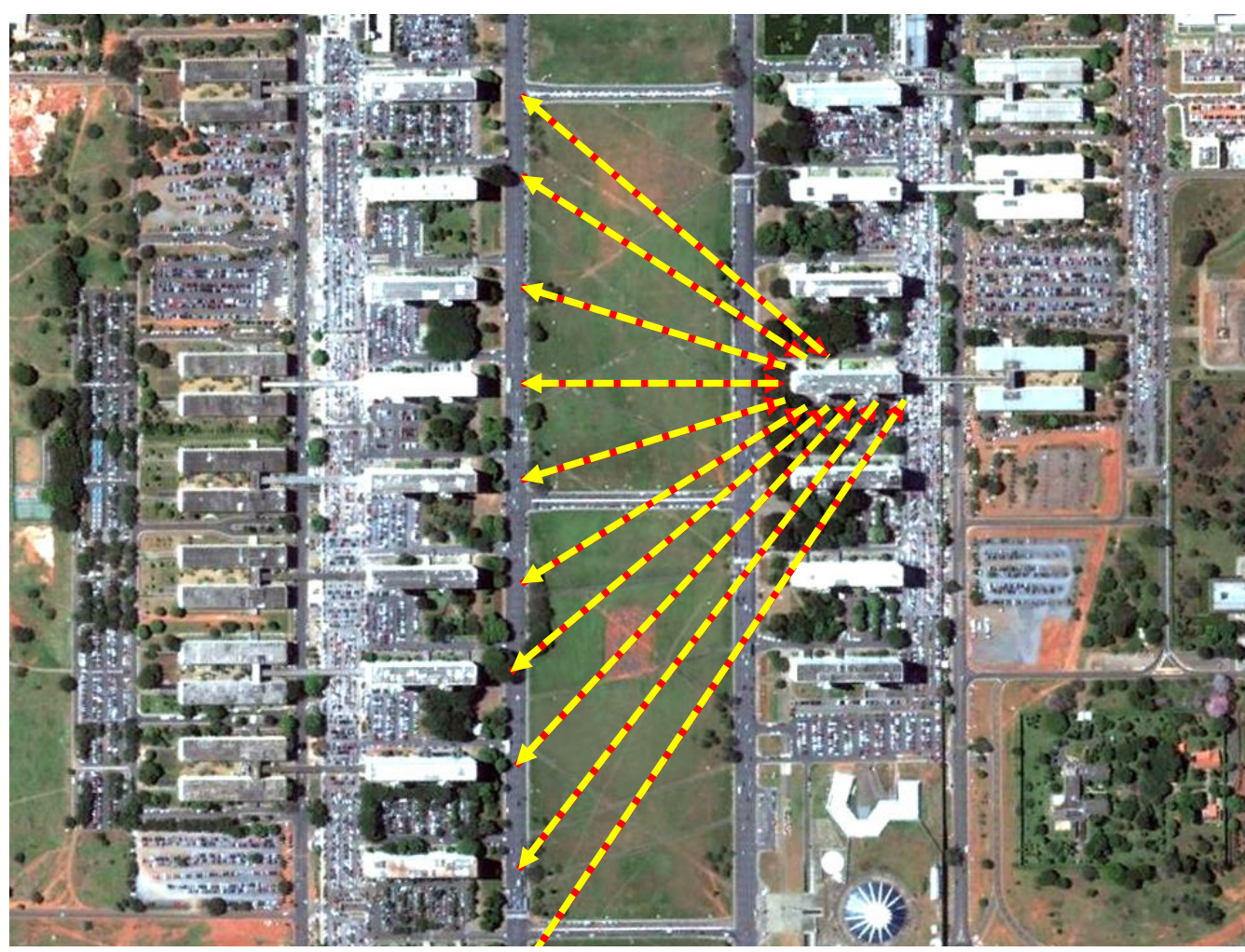

Fig. 08: Esplanada dos Ministérios em Brasília e o fluxo das ações institucionais tipo "radialdirecional". 
O modelo dispersivo para resolução das demandas territoriais no país, sobretudo as históricas, evidencia a resistência na manutenção dos valores e referências do "Brasil Colonial". A figura abaixo mostra uma modelagem gráfica de uma possibilidade de fluxo e refluxo da gestão das demandas territoriais, contexto que pode trazer mais "foco", responsabilização e eficácia na resolução dos problemas geográficos e, consequentemente, uma possibilidade de recuperação de relevância e da representatividade da Geografia no Estado.

\section{ALGUMAS REFERÊNCIAS BIBLIOGRÁFICAS}

ANJOS, R. S. A. “A geografia, a África e os negros brasileiros”. In: MUNANGA, K. (org.). Superando o racismo na escola. Brasília: Ministério da Educação, Secretaria de Educação Fundamental, 1999, p. 169-182.

.CColeção África-Brasil: Cartografia para o ensino-aprendizagem”. Brasília: Mapas Editora\& Consultoria, 2a . Edição. 2005 - BsB - DF.

ANJOS, R.S.A \& CYPRIANO, A. "Quilombolas - tradições e cultura da resistência". Aori Comunicações. Petrobrás, 2006. São Paulo, 240 p.

ANJOS, R.S.A. Coleção África-Brasil: Cartografia para o ensino-aprendizagem. Volume II Brasília: Mapas Editora\& Consultoria, Brasília, 2007.

Cartografia \& Educação. Volume I Brasília: Mapas Editora\& Consultoria, Brasília, 2007.

Quilombos: Geografia Africana-Cartografia Étnica-Territórios Tradicionais. Mapas Editora\& Consultoria, 190p. Brasília, 2009

Territorialidade Quilombola: Fotos \& Mapas / Quilombola Territoriality: Photos\&Maps. Mapas Editora \& Consultoria., 124 p. Brasília, 2011

Geopolítica da Diáspora África - América - Brasil. Séculos XV - XVI - XVII - XVIII - XIX - Cartografia para Educação. Mapas Editora\& Consultoria, Brasília, 2012 
Relatório da atualização do cadastro dos registros municipais dos territórios quilombolas do Brasil - 2012. Relatório Interno do Projeto GEOAFRO. CIGA - UnB. Brasília, 2012b.

A Territorialidade dos Quilombos no Brasil Contemporâneo: Uma Aproximação. In: SILVA, T.D. \& GOES, F.L. (org.). "Igualdade Racial no Brasil - reflexões no Ano Internacional dos Afrodescendentes”. Brasília: IPEA, 2013, p.137-152.

Atlas Geográfico ÁFRICABRASIL. Mapas Editora\& Consultoria, Brasília, 104p. 2014

O Brasil Africano - Algumas Referências dos Séculos XVI - XXI: Cartografia para Educação. Mapas Editora\& Consultoria, Brasília, 2014b

INSTITUTO BRASILEIRO DE GEOGRAFIA E ESTATÍSTICA. Dados do Censo 2010. IBGE, Rio de Janeiro, 2011 


\section{O AGORA 2015-2016: AS PESQUISAS E OS PROJETOS EM OPERACIONALIZAÇÃO}

1. A Figura da Estrutura das Referências correspondente à Etapa VI trata do momento atual e a sua configuração espacial mostra um conjunto amplo de atividades ligados a um núcleo central com dois módulos integrados. O processo de trabalho e pesquisas envolvendo os Projetos GEAFRO e Dinâmica Territorial do Brasil Central associados aos usos das ferramentas da cartografia e da fotografia possibilitaram extensões e novas abordagens para as temáticas geográficas contemporâneas conhecidas e outras que foram incorporadas. Os Programas de pesquisa conhecidos como o Monitoramento do Crescimento Urbano do DF está com uma atualização concluída para 2015, ou seja, temos a história urbana do conjunto urbano de Brasília dos anos 1950 do século XX até o presente momento. Esta atualização permite também inferir com maior propriedade os vetores de expansão operantes no território. Outro seguimento é a verificação com mais precisão dos espaços impermeabilizados (áreas que não permitem a infiltração da água) na mancha urbana. Esta cartografia é relevante para auxiliar na diminuição dos problemas de enchentes em pontos recorrentes e diferenciados no conjunto urbano de Brasília. O programa da Cartografia da Diáspora esta com uma pesquisa bem avançada da rede de cidades da Diáspora Africana no Globo. Ainda do Projeto GEOAFRO duas publicações estão no prelo: Geografia Afrobrasileira: referências para Educação e Cartografia da Diáspora: Fotos \& Mapas (planejamento nos suportes analógico e digital para 2016);

2. As orientações e pesquisas junto a Graduação, Mestrado e Doutorado estão bem desenvolvidas com estudos complementares e de aprofundamento. Destaco a Tese de Doutorado do Luiz Sanches (2014) sobre Geodireito traz elementos muitos relevantes para o estudo sobre o Brasil desorganizado institucionalmente (visível e invisível). Nesta verificamos como ao longo do Brasil Colônia, Império, República a Geografia de Estado assumiu papéis e importâncias distintas, fatos que nos possibilita entender e apontar questões estruturais da Geografia oficial do país, que praticamente deixou de existir; 


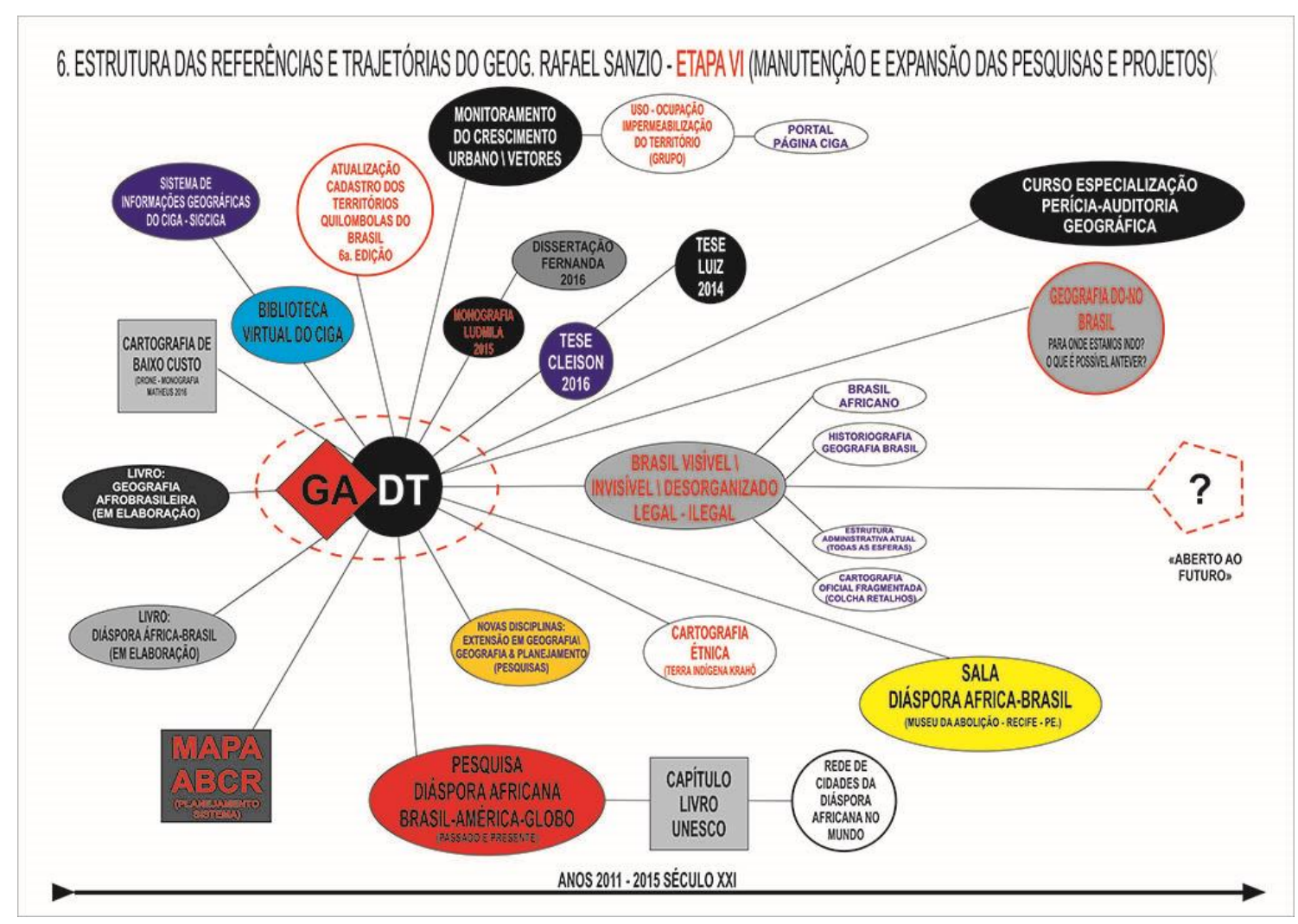

Diagrama 06

3. Elaboração do Mapa das Rede de Vias com Concessões de Uso no Brasil (ABCR). Esta parceria junto ao CIGA para elaboração de um mapa temático com os registros atualizados das empresas e seus trechos de cobrança visa auxiliar no planejamento de ações e minorar conflitos de uma cartografia desorganizada anteriormente. $\mathrm{O}$ produto trouxe como contra partida um apoio com equipamentos (drone de pequeno porte) para o desenvolvimento de pequenos projetos de cartografia de baixo custo no CIGA;

4. Na perspectiva de um melhor funcionamento e alcance acadêmico-social do seu acervo, desenvolvemos dois projetos em paralelo: $1^{\circ}$. A Biblioteca Virtual do CIGA, cujo objetivo básico é disponibilizar o conjunto de obras analógicas com as suas referências bibliográficas digitalizadas e que possibilitem o acesso dos estudantes do curso de Geografia e de outras Unidades Acadêmicas da UnB. O mesmo foi apresentado à Diretora da Biblioteca Central da UnB que apontou que o CIGA avançou no grande projeto das Bibliotecas Setoriais da Universidade. Neste sentido o nosso sistema já é uma referência do que é possível fazer; $2^{\circ}$. Trata-se do Sistema de Informação Geográfica do CIGA, conhecido como SIGCIGA, que nada mais é 
que um SIG que contém todo o acervo da universidade (com seus patrimônios), equipamentos e aquisições fruto das parcerias (com codificações especiais) e referências das pessoas que trabalham nos projetos (professores, funcionários, estudantes de Pós-Graduação, bolsistas, etc). Dessa forma, o uso dos equipamentos fica mais responsável pela equipe na medida em que o monitoramento das atividades ocorre de forma mais eficaz. O Reitor Ivan Marques foi convidado a conhecer os sistemas e se interessou por ambos para aplicar em setores específicos da UnB. O Centro de Processamento de Dados da Universidade tem se aproximado para entender melhor o potencial do SIGCIGA para a gestão universitária. O entrave está na disponibilização das informações para a formação da base informacional. Entendemos que primeiro a cultura da informação guardada e sigilosa precisa mudar em prol de uma gestão mais eficaz dos espaços, das pessoas e das demandas que envolve espaço;

5. Estamos emprestando e doando uma parte das pesquisas do Projeto GEOAFRO para a "Sala Diásporas" do Museu da Abolição em Recife - PE. É o único museu federal com foco na matriz africana. A cartografia e a fotografia são os fios condutores da comunicação de conteúdos de distintos tempos históricos e que terão tratamentos em suportes digitais de última geração. Abaixo segue dois registros da modelagem de como o espaço deverá ficar;

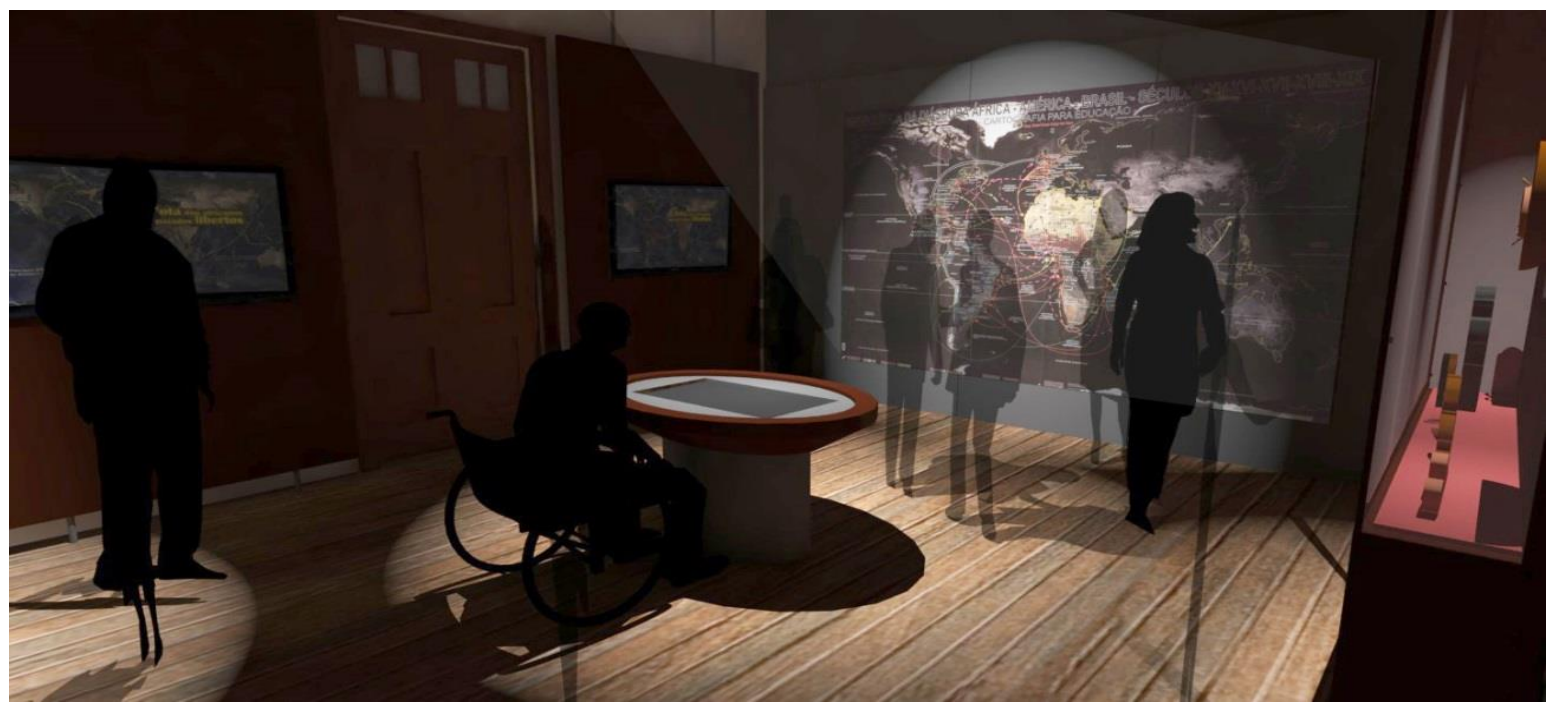

Fig 09: Registro 1- Modelagem da Sala Diáspora na reforma do Museu da Abolição. Recife - PE. 


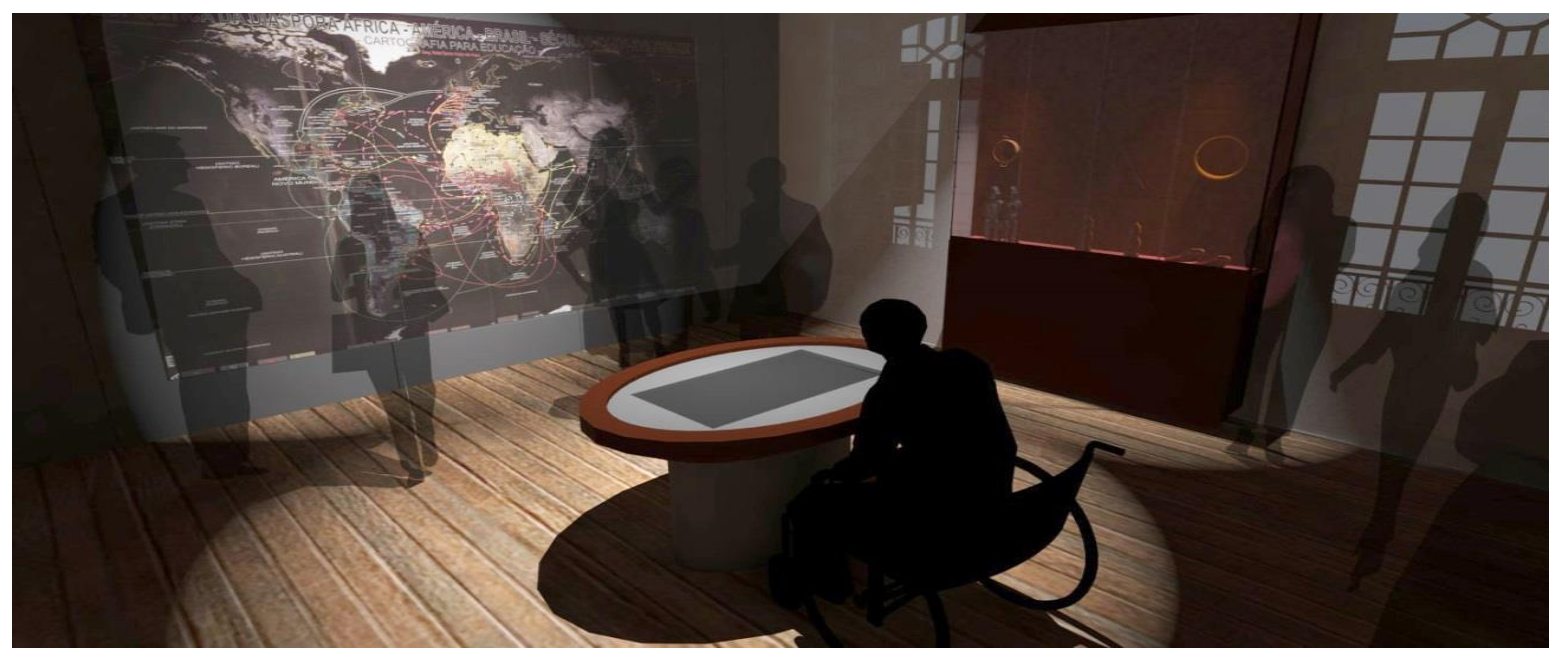

Fig 10: Registro 2- Modelagem da Sala Diáspora na reforma do Museu da Abolição. Recife - PE.

6. Organizamos este ano um Curso de Especialização em Perícia-Auditoria Geográfica para ser implementado no próximo ano uma vez que o contexto de greve dos técnicos-administrativos inviabiliza a sua realização neste ano. Abaixo o release e o folder da Pós-Graduação.

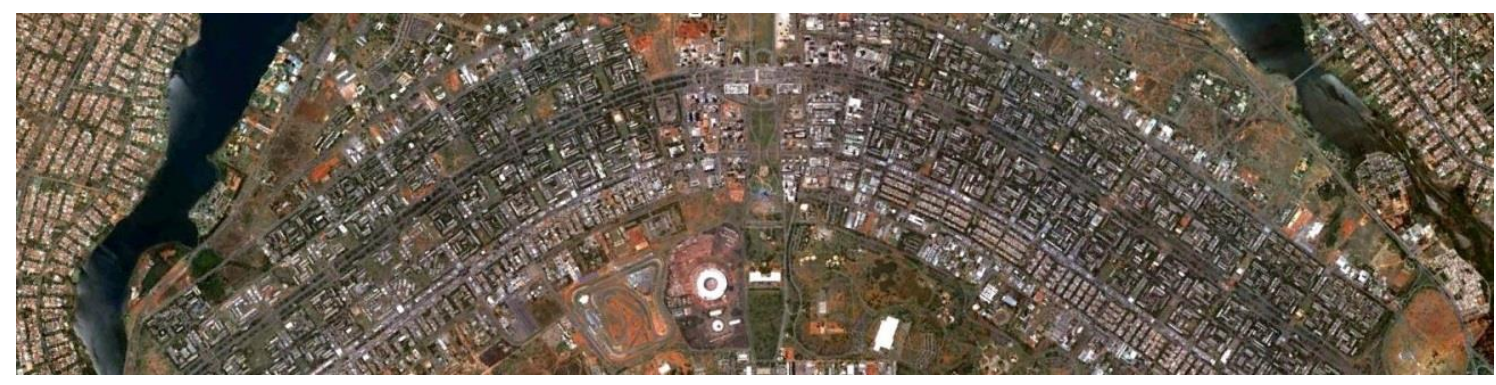

Especialização em Perícia e Auditoria Geográfica-Cartográfica:

\section{Soluções Geoespaciais}

O Centro de Cartografia Aplicada e Informação Geográfica, do Departamento de Geografia da Universidade de Brasília (CIGA/UnB) está com inscrições abertas em 2016 para o curso de especialização lato sensu em Perícia e Auditoria Geográfica-Cartográfica: Soluções Geoespaciais. O curso com 360 horas é destinado a profissionais atuantes em esferas decisórias dos poderes municipal, estadual e federal e para estudantes e técnicos que atuam com demandas de gestão territorial, como geógrafos, advogados, arquitetos e urbanistas, geólogos, engenheiros civis, agrônomos, biólogos, ecologistas, entre outros.O curso tem por objetivo 
instrumentalizar os alunos no conhecimento e na interpretação das estruturas do espaço geográfico, as suas possibilidades de representações cartográficas numa perspectiva multiescalar, além de identificar os marcos jurídicos legais existentes relacionados ao território e seus usos e possibilitar a emissão de laudos e pareceres de subsídios à gestão territorial. Tem ainda como missão capacitar profissionais no uso das referências geográficas e tecnologias cartográficas (automatizadas e analógicas) para a construção de documentos técnicos que possibilitem a caracterização e diagnóstico ambiental-espacial (auditorias geográficas) e documentação de suporte à implementação de projetos no processo de gestão e solução territorial (perícias geográficas). Serão oferecidas 30 vagas e as aulas serão ministradas de quinta a sábado, em encontros com intervalos de quinze dias.

7. Existem outros projetos menores e nem por isso menos relevantes, mas o que sinto importante na condução de um Centro de pesquisa são os "movimentos" no sentido largo (pessoas, espaço físico, atividades, tarefas) e isso possibilita uma "circulação" que mantém todos sem estar numa "zona de conforto". O inesperado é quase que uma regra porque eu e a equipe aprendemos muito e esses contextos nos fortalecem. Fecho este memorial com uma citação do velho mestre (na página a seguir) que muito me guiou com seus escritos na minha trajetória!

\section{Axé!

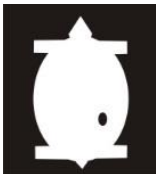




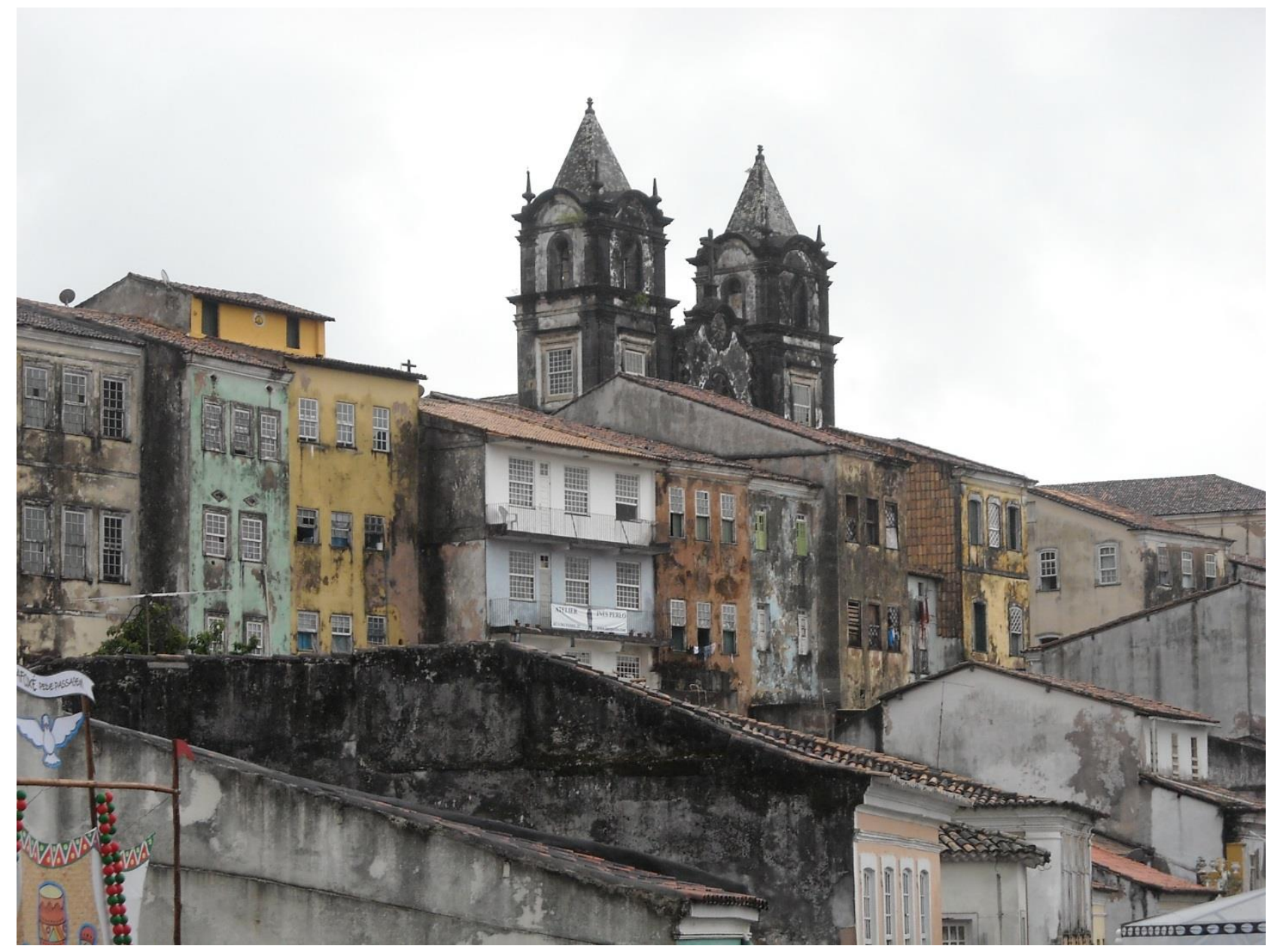

“A ação é sepre presente, não há ação passada, nem ação futura.

\section{Há apenas ação presente.}

E ação, de alguma forma, resulta de escolhas."

Milton Santos, 1998 


\section{ANEXOS}

\section{HISTÓRICO DAS OBRAS}

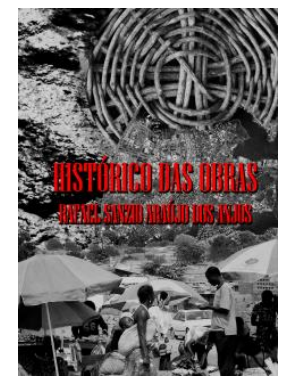

LINK:

http://ciga.unb.br/images/stories/CIGA/media/histricos\%20word\%20versao\%20pagina \%201.pdf

\section{LINKS RELEVANTES:}

\section{LATTES - CNPQ}

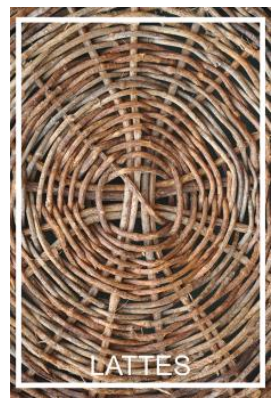

LINK: http://buscatextual.cnpq.br/buscatextual/visualizacv.do?id=K4787860U4 


\section{GOOGLE ACADEMICS}

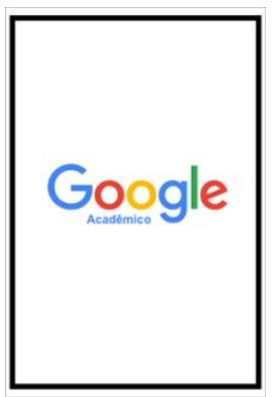

Link: https://scholar.google.com.br/scholar?hl=ptBR\&q=rafael+sanzio+araujo\&btnG=\&lr=

\section{PORTAL DE PUBLICAÇÕES E OBRAS}

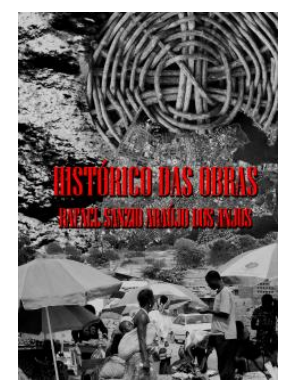

\section{Link:}

http://ciga.unb.br/images/stories/CIGA/media/histricos\%20word \%20versao\%20pagina\%201.pdf

\section{REPOSITÓRIO BC UNB}

http://repositorio.unb.br/handle/10482/129/simplesearch?query $=$ rafael+sanzio+araujo

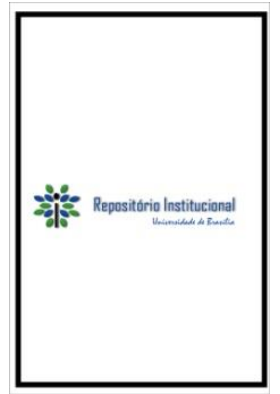

